University of Rhode Island

DigitalCommons@URI

Open Access Master's Theses

2007

\title{
Assessing the Effects of Fluctuating River Stage on an MTBE Containment Plume Discharging to Surface Water, Pascoag, RI
}

James L. Allen

University of Rhode Island

Follow this and additional works at: https://digitalcommons.uri.edu/theses

\section{Recommended Citation}

Allen, James L., "Assessing the Effects of Fluctuating River Stage on an MTBE Containment Plume Discharging to Surface Water, Pascoag, RI" (2007). Open Access Master's Theses. Paper 1096.

https://digitalcommons.uri.edu/theses/1096

This Thesis is brought to you for free and open access by DigitalCommons@URI. It has been accepted for inclusion in Open Access Master's Theses by an authorized administrator of DigitalCommons@URI. For more information, please contact digitalcommons-group@uri.edu. 
ASSESSING THE EFFECTS OF FLUCTUATING RIVER STAGE ON AN MTBE CONTAMINANT PLUME DISCHARGING TO SURFACE WATER, PASCOAG, RI

\section{BY}

JAMES L. ALLEN

A THESIS SUBMITTED IN PARTIAL FULFILLMENT OF THE

REQUIREMENTS FOR THE DEGREE OF

MASTER OF SCIENCE

IN

ENVIRONMENTAL SCIENCES

UNIVERSITY OF RHODE ISLAND 
MASTER OF SCIENCE

OF

JAMES L. ALLEN

APPROVED:

Thesis Committee:

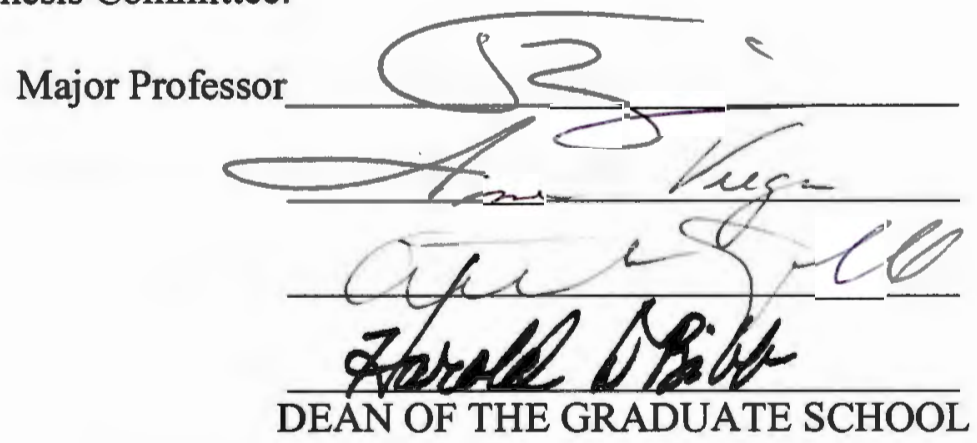

UNIVERSITY OF RHODE ISLAND 


\begin{abstract}
Ground-water/surface-water interactions and MTBE contaminant plume discharge were investigated in a low-order river that experiences episodic river stage fluctuations. Results show that the hydraulic gradient fluctuates hourly to monthly due to river stage changes, water table recharge events, and reservoir gate adjustments. Hyporheic exchange driven by channel morphology creates small-scale gaining, losing, and parallel flow systems along the mostly gaining reach. During precipitation events, infiltrating rainfall rapidly saturates the extended capillary fringe and the shallow floodplain water table rises forming a ground-water ridge or mound and causing a steepened hydraulic gradient towards the river. The system response is magnified by watershed characteristics which control the river stage hydrograph including stormflow lag and flashiness.

Results of this study suggest that a ground-water plume discharging to surface water may have several discharge locations related to transient water-table configurations. Under conditions of a low hydraulic gradient, the MTBE plume is deflected away from the river by hyporheic flow toward a downstream discharge location. When the gradient toward the river steepens in response to precipitation and gate closure, the small-scale hyporheic exchange systems are overcome and the plume discharges along the entire reach. Under these conditions, a high influx of contaminated ground water is discharged from the floodplain to the river, temporarily elevating river contaminant concentrations. During site investigation and monitoring, these transient spatial and temporal relationships could easily be missed by traditional site monitoring strategies.
\end{abstract}




\section{ACKNOWLEDGEMENTS}

I would like to thank my thesis advisor, Dr. Thomas B. Boving, for his assistance and for providing me with the opportunity for such a rewarding research project. I would also like thank Dr. Anne I. Veeger for instilling in me the principles of hydrogeology that served as the platform for my research and for answering many questions along the way. Thank you also to Dr. Arthur Gold, whose timely guidance was much appreciated and to the thesis committee chair, Dr. Rainer Lohmann.

There are also several people from the Pascoag site who have helped make this research possible. A special thanks to Michael Cote and the FIRST team of the Rhode Island Department of Environmental Management for allowing me access to the site and providing me with required resources. I also would like to thank the Valliere family for land access to my study area and also Leo Plouffe and the Pascoag Reservoir Association for providing me gate and reservoir information.

Thank you to the department faculty and staff and all of my fellow graduate students for providing support, comic relief, and friendship. And finally, a special thanks to my family who have supported me throughout my graduate school experience. 


\section{PREFACE}

This thesis is written in manuscript format, with the main body comprising the publishable text and supplemental information provided in appendices. The format is consistent with articles published in the journal Ground Water, the journal in which I intend to publish. 


\section{TABLE OF CONTENTS}

ABSTRACT

ACKNOWLEDGEMENTS ............................................................................................

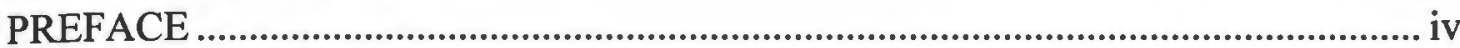

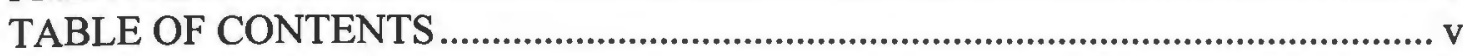

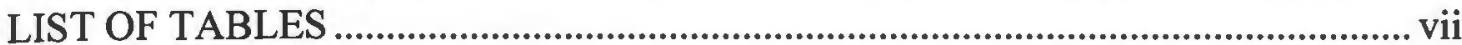

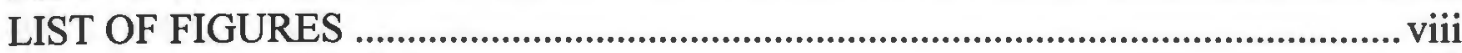

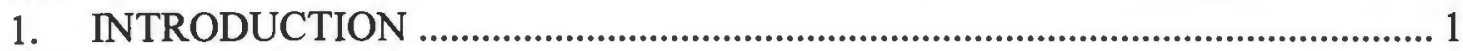

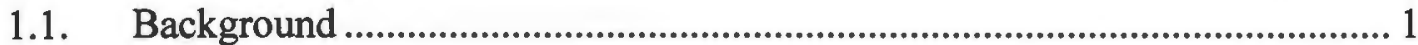

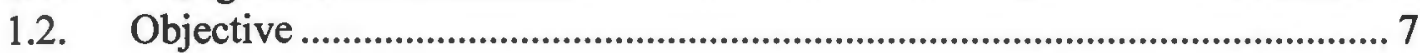

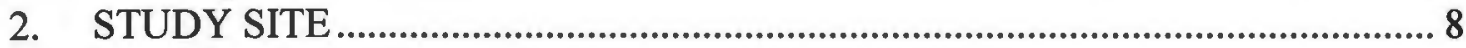

2.1. General Background....................................................................................... 8

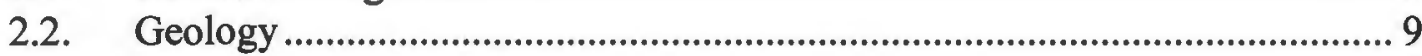

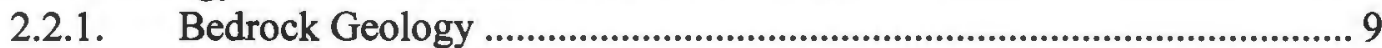

2.2.2. Surficial Materials............................................................................. 10

2.2.3. Surface-Water Hydrology .............................................................. 11

2.2.4. Hydrogeology..................................................................................... 14

2.2.5. Ground-water/Surface-Water Interaction............................................ 14

2.3. Contaminant Fate and Transport.............................................................. 15

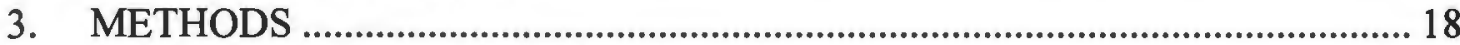

3.2.1. Sampling and Field Parameters........................................................... 20

3.2.2. Water Table Measurements............................................................... 21

3.2.3. Temperature Measurements ................................................................. 21

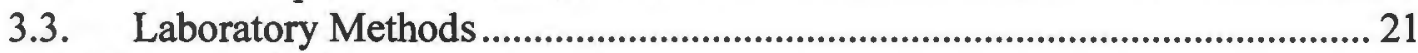

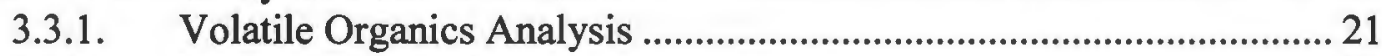

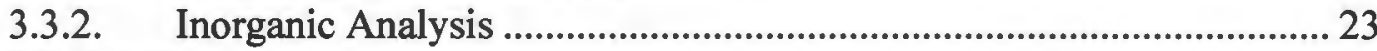

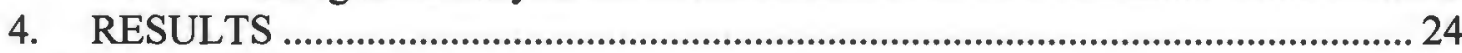

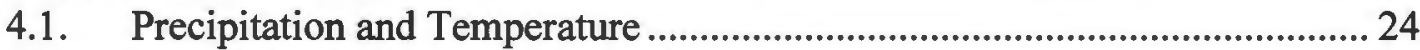

4.2. Reservoir Discharge and River Stage .......................................................... 24

4.3. Water-Table Elevations...................................................................................... 26

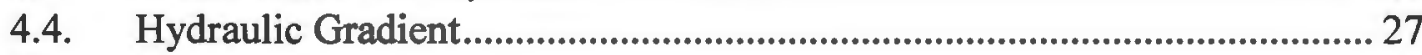

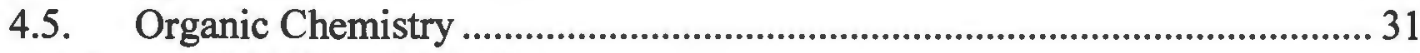

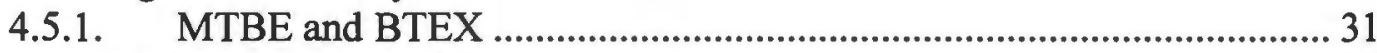

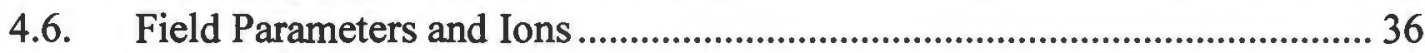

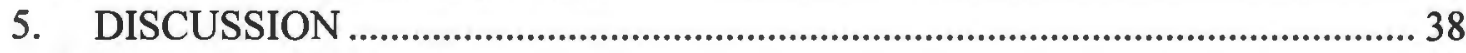

5.1. Hyporheic Exchange .............................................................................. 38

5.2. Floodplain Processes............................................................................. 41

5.2.1. Low River Stage................................................................................ 42

5.2.2. High River Stage ..................................................................................... 45

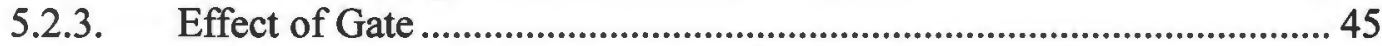

5.3. Comparison to other GW/SW interaction studies......................................... 46

5.4. Contaminant Fate and Transport.................................................................. 48

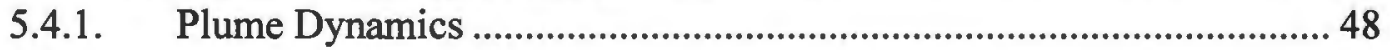

5.4.2. Ground-water Monitoring and Natural Attenuation ............................. 50

5.5. Limitations and Sources of Error ............................................................ 52 


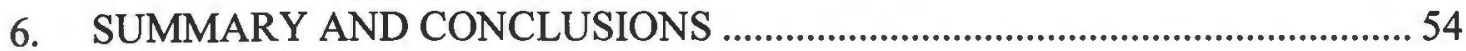

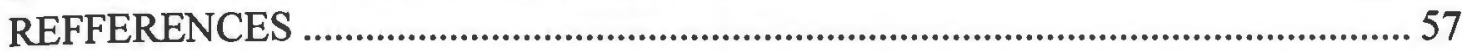

APPENDIX I: STUDY SITE................................................................................... 63

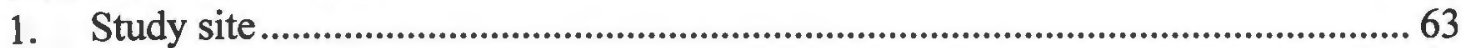

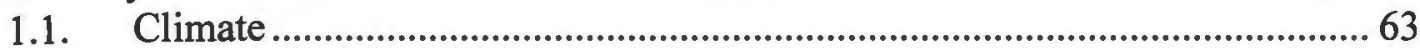

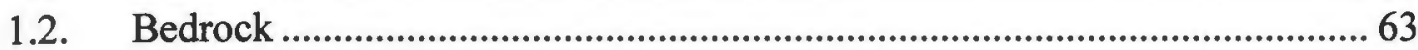

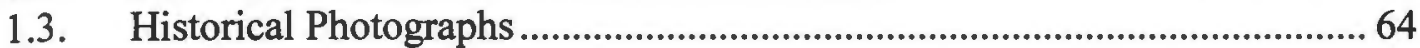

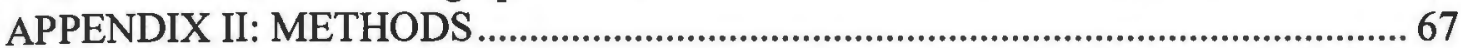

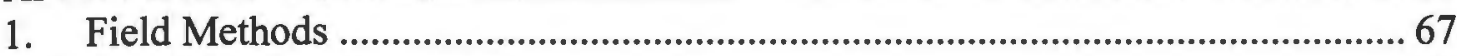

1.1. Well Installation and Surveying.............................................................67 67

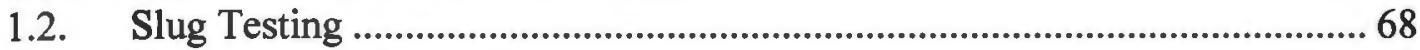

1.3. Equipment and Specifications....................................................................6 69

1.4. River Discharge..................................................................................... 70

2. Laboratory Methods ........................................................................................... 70

2.1. Volatile Organics Analysis .................................................................... 70

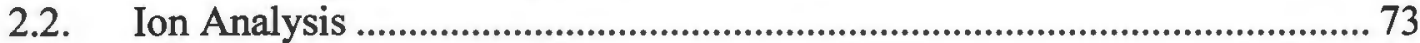

3. Precipitation and Temperature …................................................................... 74

APPENDIX III: RESULTS AND DISCUSSION ................................................. 76

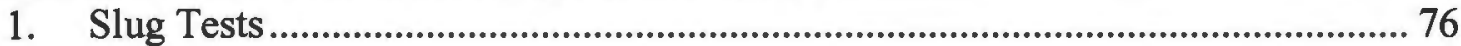

2. Hydraulic Gradient.................................................................................................... 82

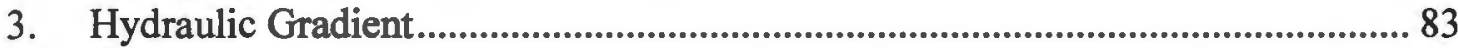

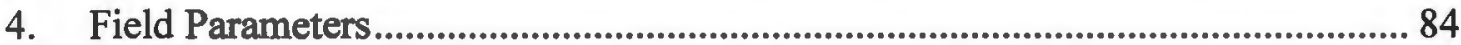

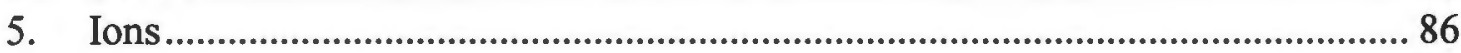

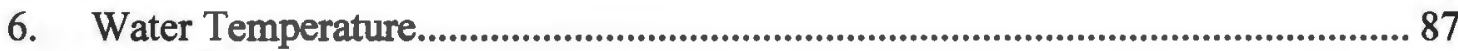

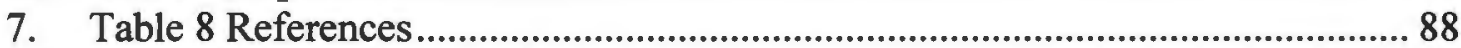

APPENDIX IV: SUPPLEMENTARY GRAPHS................................................. 89

APPENDIX V: SUPPLEMENTARY TABLES................................................... 107

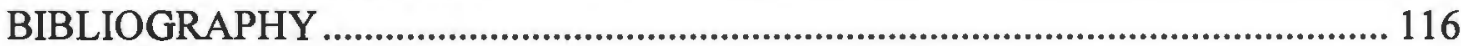




\section{LIST OF TABLES}

Table 1. Watershed and statistics for Pascoag River. ................................................... 12

Table 2. Well construction and well location information........................................ 18

Table 3. Target VOCs and minimum detection limits........................................... 22

Table 4. Water table monitoring information and elevations. ....................................2 26

Table 5. Horizontal and vertical hydraulic gradient realtionships ............................... 28

Table 6. Summary of VOC analyses for MTBE and BTEX..................................... 32

Table 7. Average ion concentrations........................................................................... 36

Table 8. Temperature monitoring information and summary..................................... 37

Table 9. Factors controlling hydraulic gradient response in the floodplain................. 41

Table 10. Literature comparison of watershed area to stormflow response. .............. 47

Table 11. Transducer measurement QA/QC.................................................................. 52

Table 12. List of field equipment and specifications ....................................................69

Table 13. GC/MS and purge and trap operating parameters...................................... 71

Table 14. Stock standard vendor and concentrations................................................. 72

Table 15. Anion and cation calibration levels.................................................................. 74

Table 16. Anion and cation calculated MDLs, ............................................................ 74

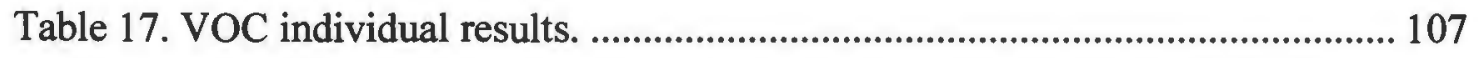

Table 18. Ion individual concentrations..................................................................... 112 


\section{LIST OF FIGURES}

Figure 1. Cross-section of ground-water and near-channel flow.................................... 4

Figure 2. Site location in Pascoag, Rhode Island........................................................ 8

Figure 3. Conceptual cross-section of site looking north-northeast............................... 9

Figure 4. Watershed for Pascoag River......................................................................... 11

Figure 5. MTBE contaminant distribution at the start of this study in $2006 . . . \ldots . . . . . . . . .16$

Figure 6. Monitoring well and riverbed well locations used in this study................... 19

Figure 7. Precipitation and average temperature measured during this study............. 24

Figure 8. Pascoag Reservoir water level and sluice gate opening. ................................ 25

Figure 9. River stage hydrograph and controlling factors, precipitation and gate

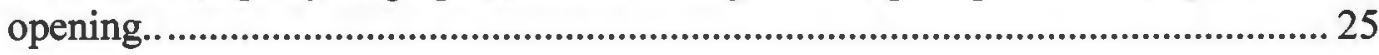

Figure 10. Water table elevations obtained by dataloggers. .......................................... 27

Figure 11. Hydraulic gradient between JA 2S and the river........................................ 28

Figure 12. Generalized vertical gradient in the floodplain during losing period $(3 / 28 / 06)$ and during gaining period $(5 / 11 / 06)$........................................................ 29

Figure 13. Hydraulic gradient in upgradient floodplain wells between MW 56, MW 44, and MW 18........................................................................................................ 30

Figure 14. Floodplain ground-water flow regimes. .................................................... 31

Figure 15. MTBE and BTEX concentration data for floodplain wells........................ 33

Figure 16. MTBE and BTEX concentrations in the river............................................. 34

Figure 17. MTBE and BTEX concentrations in riverbed wells................................... 35

Figure 18. Channel morphology along river reach................................................ 40

Figure 19. 24-hour river stage and water table response to precipitation event on 4/23 $4 / 24$.

Figure 20. Conceptual model of ground-water flow in floodplain. 
Figure 21. Rose diagram of bedrock fracture trends collected from outcrops in and around Pascoag.

Figure 22. Former textile factory at the site. 65

Figure 23. 1939 Aerial photograph of the textile factory...............................................6 66

Figure 24. Floodplain ground-water flow regimes. ................................................... 82

Figure 25. Hydraulic gradient from JA 3D to JA 2D.................................................. 83

Figure 26. Hydraulic gradient between JA 3D and the river. ..................................... 84

Figure 27. Graphs of electrical conductivity (EC), dissolved oxygen (DO), and pH. . 89

Figure 28. Graphs of ion concentrations ................................................................. 94

Figure 29. Graphs of floodplain well temperatures. .................................................. 105

Figure 30. Graphs of riverbed well temperatures........................................................ 106 


\section{INTRODUCTION}

\subsection{Background}

Rising population and urban development have placed increasing pressure on the availability and quality of ground-water and surface-water resources (Einarson and Mackay 2001; Job and Simons 1996; Moran et al. 2005; Winter et al. 1998). With escalating concern and knowledge that ground-water and surface-water systems are intrinsically linked, current research is focusing on improving the conceptual model of ground-water/surface-water (GW/SW) interactions. Model accuracy is of even greater importance where contaminated ground water discharges to surface water. The EPA estimates that $75 \%$ of Superfund and RCRA sites are located within a half mile of a surface-water body and nearly half have impacted surface-water quality (Tomassoni 2000). How these ground-water plumes interact with surface water, both spatially and temporally, is therefore of paramount interest.

Study of GW/SW interaction crosses the boundaries of hydrology, biology, geomorphology, and aquatic chemistry. Research has sought to increase understanding in the contexts of water resources management (riverbank filtration and stream depletion), stream and riparian health (nutrient cycling and benthic biota), flood modeling (bank storage and floodplain hydrology), and ground-water contamination (point and non-point source). Research on these topics has focused primarily on the hydraulic relationships between the coupled systems. For example, early researchers developed the conceptual framework for the hydraulics of flow, transport, and exchange across the GW/SW interface. Subsequent researchers have modified and expanded these concepts with studies that have helped explain the 
controls on the hydraulic gradient. Current understanding states that GW/SW interaction is controlled by the distribution and magnitude of hydraulic conductivity, the relation of stream stage to the adjacent ground-water gradient, and the geometry and position of the channel within the floodplain (Woessner 2000). In GW/SW systems (i.e., rivers and adjacent aquifers) the following hydraulic relationships are possible: 1) ground water can enter the channel (gaining), 2) ground water can exit the channel (losing), 3) ground water can travel parallel to the channel (parallel-flow), or 4) ground water can simultaneously enter and exit the channel (flow-through).

Early work through the 1980 s on GW/SW interaction was conducted broadly on the topic, including quantifying stream depletion due to irrigation well pumping (Sophocleus et al. 1988) and early modeling of flood-induced bank storage (Gill 1985). As understanding increased and the practical importance of this coupled system was realized, studies on floodplain hydraulics grew more specialized and began to include stormflow and riparian processes.

Most conceptual models of stormflow events for gaining rivers show that as river stage rises, the hydraulic gradient adjacent to the channel reverses from gaining to losing and river water is driven into the aquifer. This process, termed bank storage, has been shown to help to attenuate stormflow (Burt et al. 2002; Stewart et al. 1999). Following the passage of peak flow, the gradient reverses back to gaining and the stored water gradually returns to the river channel as return-flow. Others have shown that the shape of the flood hydrograph, geometry of the channel and floodplain, and aquifer properties can affect bank storage and return flow (Chen and Chen 2003; Girard et al. 2003; Hantush 2005; Serrano and Workman 1998; Vidon and Hill 2004). 
A suite of other factors have also been identified that affect the degree and timing of the hydrologic response in the floodplain. For example, floodplain recharge by precipitation and surface runoff was studied by Barlow et al. (2000) and shown to increase return flow discharge by steepening the hydraulic gradient towards the river. Zhang and Schilling (2006) showed that vegetation can affect shallow floodplain water tables and stream flow by controlling soil moisture. The degree of forestation has also been shown to be a significant factor controlling large-scale watershed recharge and stream flow (Nichols and Verry 2001). High floodplain water tables can also affect the response to recharge and overbank inundation by increasing antecedent soil moisture (Burt et al 2002; Girard et al. 2003). In addition, stormflow and bank storage is also a concern at riverbank filtration sites due to the threat of surface water contamination and gradient alteration (Schubert 2002; Sheets et al. 2002; Wett et al. 2002).

Besides the overall GW/SW hydraulic relationship within a river reach, smallscale variations that govern the hydraulics beneath river channels are driven by hyporheic exchange processes. The hyporheic zone is broadly defined as the area beneath and adjacent to a river channel that contains some proportion of surface water and ground water (White 1993; Woessner 2000). Research has shown that the hyporheic zone plays a key role in ecosystems due to the many physical, geochemical, and biological processes occurring therein which often control stream and riparian health (Castro and Hornberger 1991; Hayashi and Rosenberry 2002; Hunt et al. 2006; Kasahara and Wondzell 2003; Triska et al. 1989; Wroblicky et al.1998). These processes are sensitive to hyporheic exchange variability which can create spatially 


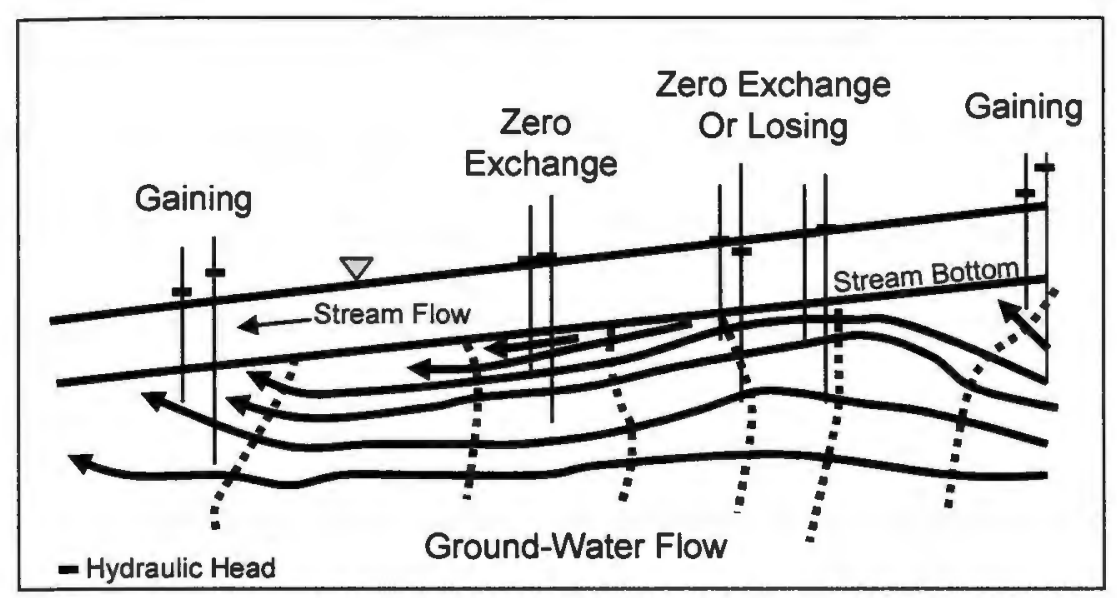

Figure 1. Cross-section of ground-water and near-channel flow demonstrates development of gaining, losing, and zero exchange along a single river reach. Hydraulic head in riverbed piezometers indicates the gaining/losing relationship between the river, hyporheic zone, and riparian zone ground water (Modified after Woessner 2000).

limited gaining, losing, and parallel-flow river conditions within a single reach (Figure 1) (Stonestrom and Constantz 2004; Woessner 2000).

The influence of channel morphological features on the development, location, and characteristics of the hyporheic zone has received considerable attention. Studies have demonstrated that channel bedforms, pool-and-riffle sequences, meander bends, changes in slope, and debris dams play a considerable role in determining the presence and type of hyporheic exchange (Boano et al. 2006; Cardenas et al. 2004; Harvey and Bencala 1993; Lautz and Siegel 2006). Conant Jr. (2004) showed that streambed heterogeneity can also result in spatially-limited discharge zones responsible for the majority of reach ground-water discharge along a reach. The dominant hyporheic control acting on a stream is related to stream gradient, sinuosity, and other geomorphic factors, which also control the path lengths and residence time of hyporheic exchange. Kasahara and Wondzell (2003) showed that compared to fifthorder rivers, exchange in second-order rivers tends to have shorter residence time due to the abundance of pool-and-riffle sequences and debris dams. Others have shown 
that hyporheic exchange in low-order rivers is highly transient and can either appear, contract, expand, or relocate with small modifications to the dynamic system (Hunt et al. 2006; Winter et al. 1998; Wroblicky et al. 1998). While higher order rivers do exhibit hyporheic variability, flow path lengths and residence times are considerably longer (Lambs 2004).

Surface-water discharge is commonly the ultimate fate of ground water contaminated by point or non-point sources. The transport and behavior of these contaminants across the GW/SW interface includes multiple dynamic processes that control the concentration, distribution, and location of discharge. Research has shown that riparian and hyporheic zone processes play an important role in controlling the quality of this water prior to discharge. Non-point source contamination, such as nitrate introduced through regional fertilizer usage, can be largely removed from ground water with a healthy riparian buffer zone (Hayashi and Rosenberry 2002). However, alteration of the vegetation can impact the water table and can be detrimental to nutrient uptake and cycling (Schilling et al. 2004; Schilling et al. 2006). A pan-European study by Burt et al. (2002) identified geomorphic and climate factors as important processes in controlling riparian zone water tables, hydraulic gradients, and the position of the GW/SW interface.

Typical point-sources of contamination include landfills, leaking underground storage tanks (LUST), military bases, and industrial facilities with contaminants varying from metals to volatile and semi-volatile organic contaminants (VOCs and SVOCs). Major point sources of ground-water contamination are commonly located adjacent to surface water, presumably due to current or former usage for transportation 
and power (Tomassoni 2000). It is therefore surprising that there has been relatively little research investigating the behavior of ground-water contaminant plumes discharging to surface water.

In a GW/SW exchange system, the hydraulic gradient has the strongest influence on the ultimate discharge location relative to the source zone. For example, Hinzman et al. (2000) showed that increased river stage and bank storage can affect plume discharge and also natural attenuation due to dispersion, dilution, and smearing. They also suggest natural discharge as a remediation alternative due to potentially high contaminant mass discharged from the ground-water system to the surface-water system. Others have shown that fluctuating river stage has the potential to affect contaminant discharge rates and the position of the GW/SW interface (Kim and Hemond 1998; Westbrook et al. 2005).

In what the authors described as the first assessment of a perchloroethylene (PCE) plume discharging to surface water, Conant Jr. et al. (2004) explained observations by pointing to heterogeneous hydraulic conductivity, organic carbon sorption, biodegradation, and variations in source zone contributions. Their study provided a snapshot of contaminant distributions and hydraulic relationships rather than a transient analysis. Fryar et al. (2000) included transient discharge in a study of a VOC contaminant plume entering a river. They identified temporary reversals in hydraulic gradient and riverbed discharge associated with local storms, flooding, and dry periods that altered contaminant discharge and shifted the discharge location of the plume. They also identified increased return-flow ground-water discharge following flooding, possibly associated with increasing VOC concentrations in the river. 
These studies demonstrate the complex transient relationships affecting discharge of contaminated ground water to surface water. Currently, no clear conceptual model exists for describing mechanisms and spatial and temporal variability of ground-water plumes discharging to rivers. This study will therefore address this need by examining the conceptual model of transient GW/SW hydraulic relationships and their resulting affects on discharging plumes.

\subsection{Objective}

This thesis examines the interaction of a gasoline contaminated ground-water plume with the Pascoag River, a low-order river that experiences episodic river stage fluctuations due to controlled reservoir discharge and stormflow. My hypothesis was that ground-water and surface-water hydraulic relationships change in response to river stage fluctuations resulting in spatial and temporal alterations to the fate and transport of the discharging contaminant plume. Specifically, spatial and temporal changes in the hydraulic gradient and plume discharge in relation to river stage were investigated. These changes alter the dynamic equilibrium that occurs between the ground-water and surface-water systems and the established location and groundwater flux into the river channel. Changes in degradation rates, sorption, and the solubility of gasoline compounds were not specifically addressed in this study. In an effort to capture plume transience, data collection incorporated high resolution water table and river stage measurements, along with ground-water sampling for VOCs from a series of monitoring well and surface-water locations. The outcome of this research has practical application to this LUST site and to improving the conceptual model of ground-water plumes discharging to surface water in general. 


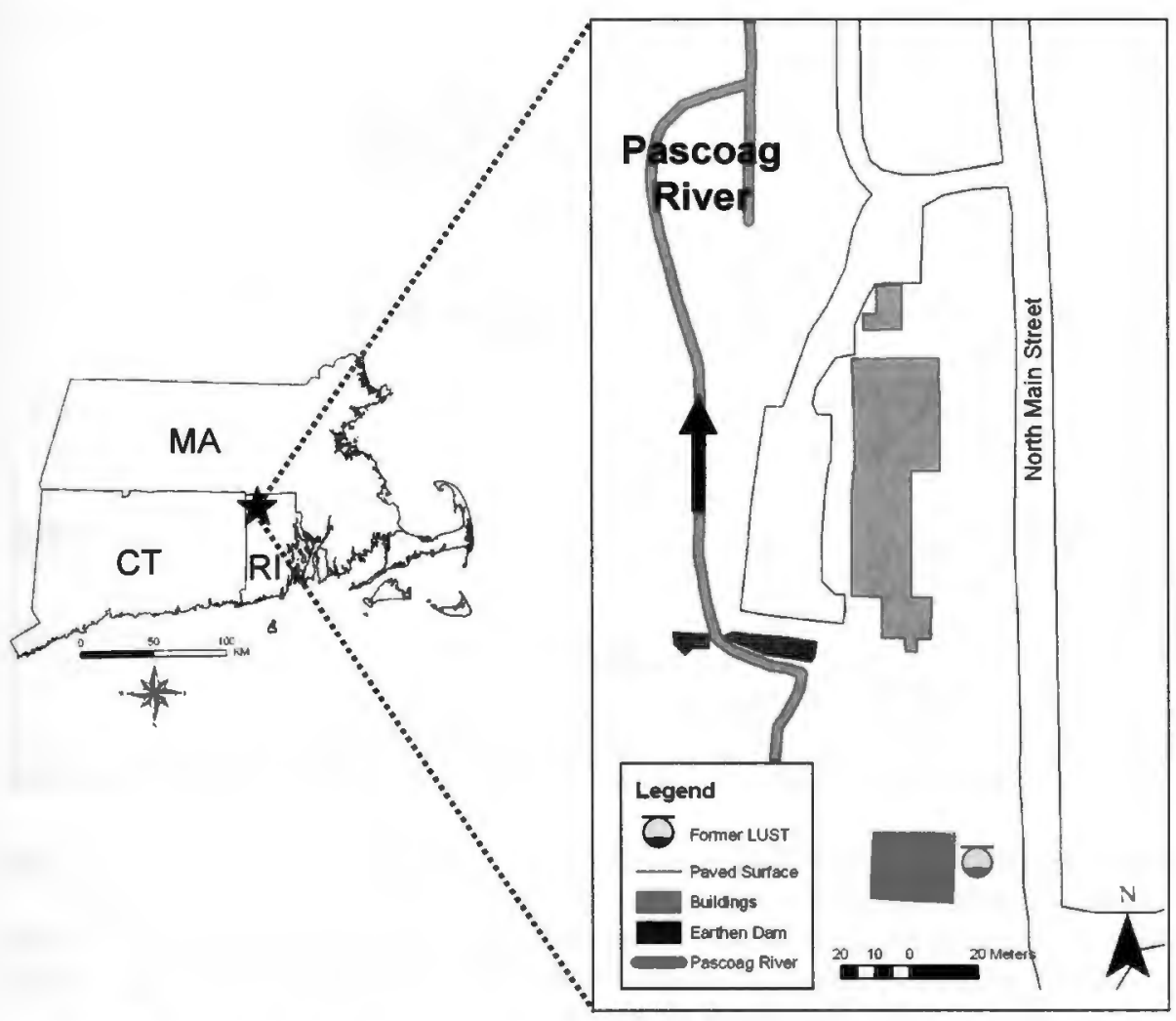

Figure 2. Site location in Pascoag, Rhode Island. Gasoline contaminants originated from a LUST located south of the town's supply well. After the well was shut down, the contaminant plume shifted toward the Pascoag River, which flows north along the site. The earthen dam owes its origin to a textile factory that once existed at the site. A now-buried channel originated from a sluice and flowed parallel to Pascoag River connecting to the channel to the north.

\section{STUDY SITE}

\subsection{General Background}

The study site is in Pascoag, Rhode Island, a small village in the town of Burrillville (Figure 2) $\left(42.0^{\circ} \mathrm{N}, 71.7^{\circ} \mathrm{W}\right)$. The village has a population of approximately 7,100 with residential housing as the predominant land use adjacent to the study site (Missouri Census Data Center 2006). The site is currently under supervision of the Rhode Island Department of Environmental Management (RIDEM) after a UST leaked more than 11,000 liters of gasoline into the shallow ground water in 2001 (RIDEM unpublished data). The study site for this thesis is located along Pascoag River (Figure 2) where the contaminant plume discharges to the river. Surface 


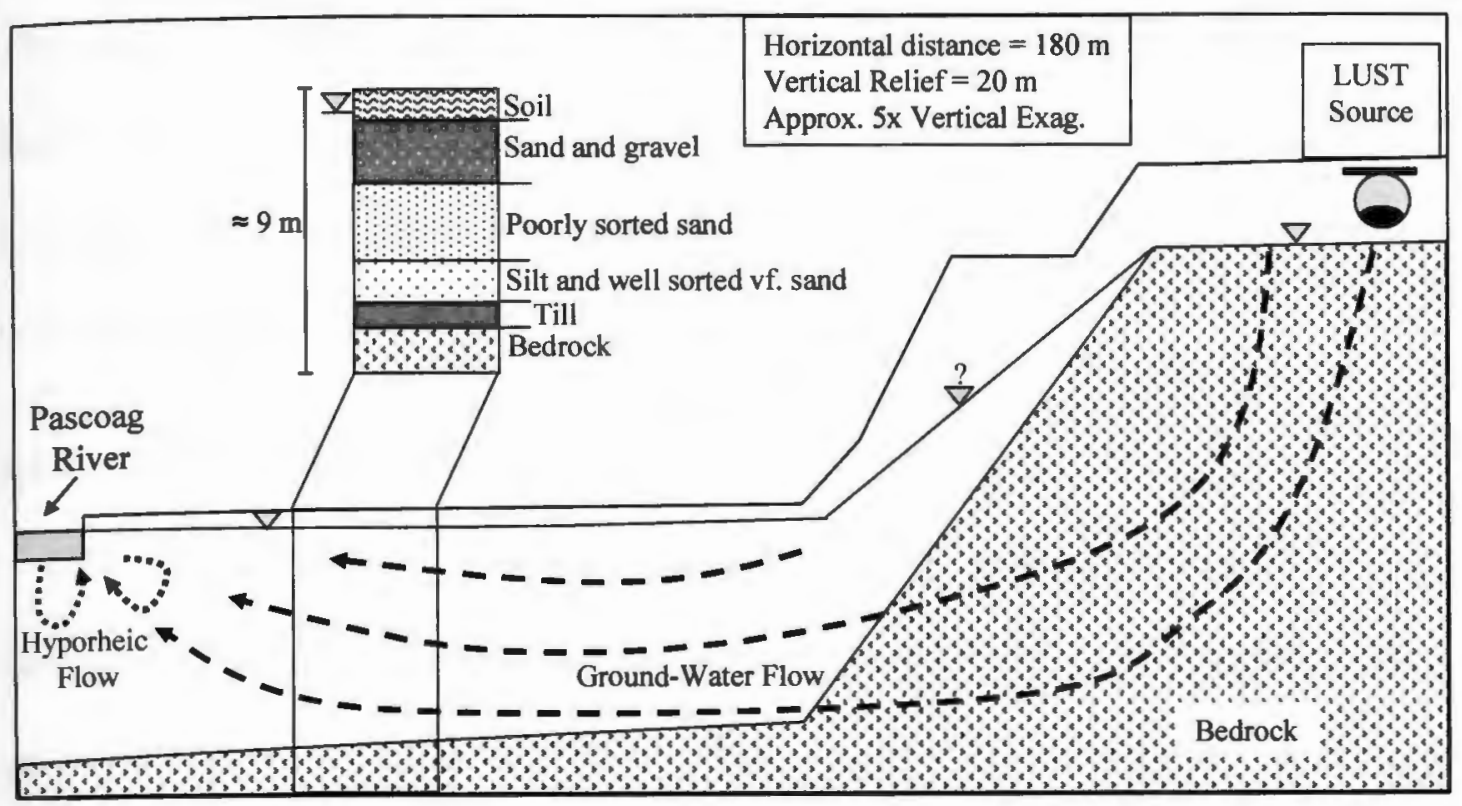

Figure 3. Conceptual cross-section of site looking north-northeast. Shows the general surface and bedrock topography based on refusal depths and geophysics. Contaminants flow through bedrock fractures toward the floodplain and are believed to discharge at the base of the stratified sand, silt, and gravel aquifer. The water table in the floodplain is shallow and frequent ponding occurs on the surface.

elevation ranges from $111 \mathrm{~m}$ above sea level in the study area to $122 \mathrm{~m}$ at the source zone (Figure 3).

In September of 2001, the gasoline additive methyl tert-butyl ether (MTBE) was detected in drinking water from Pascoag's municipal supply well. An onsite investigation led by the RIDEM found the source of the contamination to be a gas station $460 \mathrm{~m}$ upgradient from the supply well. The well was permanently shut down in January of 2002 after an alternate drinking water source was established.

\subsection{Geology}

\subsubsection{Bedrock Geology}

The topography of the bedrock surface varies significantly across the aquifer and controls local surface topography. Bedrock depth ranges from less than $3 \mathrm{~m}$ at the source zone to $8 \mathrm{~m}$ below ground surface at the study site, deepening toward the river. 
The bedrock is augen granite gneiss with predominant fractures striking nearly northsouth with an average dip of $65^{\circ} \mathrm{E}$ and a second set striking $\mathrm{N} 75^{\circ} \mathrm{W}$ with a dip of $75^{\circ}$ S (Allen and Boving 2006). A complete description of bedrock lithology and fractures is provided in Appendix I.

\subsubsection{Surficial Materials}

The thickness of the stratified sand and gravel aquifer at the site varies from $3 \mathrm{~m}$ at the source zone to $8 \mathrm{~m}$ in the study area, increasing towards the river (Figure 3 ). The aquifer is believed to be glacial deltaic in origin and contains heterogeneous sediments ranging from silt to sand and gravel (Allen unpublished report 2005). Based on sediment borings from adjacent to the study area, the base of the $8 \mathrm{~m}$ unconsolidated aquifer is dense till overlain by silt and well-sorted very fine sand (Figure 3). This is followed by poorly sorted sand and capped by sand and gravel. The soil is mapped as Canton and Charlton extremely stony fine sandy loam and has moderately rapid permeability and moderate water capacity (Rector 1981). The soil horizons may be significantly disturbed and some areas may be covered with fill material related to a former textile factory. Historical photographs (Appendix I) show the factory and suggest that building foundation debris and a buried channel remain in the study area.

Due to the heterogeneous nature of the aquifer, there is large range in hydraulic conductivity $(\mathrm{K})$ of the aquifer material. Bouwer-Rice falling head slug tests for the aquifer indicate a $\mathrm{K}$ range of $10^{-2}$ to $10^{-5} \mathrm{~cm} / \mathrm{sec}$ (RIDEM unpublished data) with a somewhat narrower range of $10^{-3}$ to $10^{-4} \mathrm{~cm} / \mathrm{sec}$ on the study site along the river as determined in this thesis (Appendix III). This range is consistent with fine to coarse sands, with the degree of sorting having a significant impact on the $\mathrm{K}$ value. 


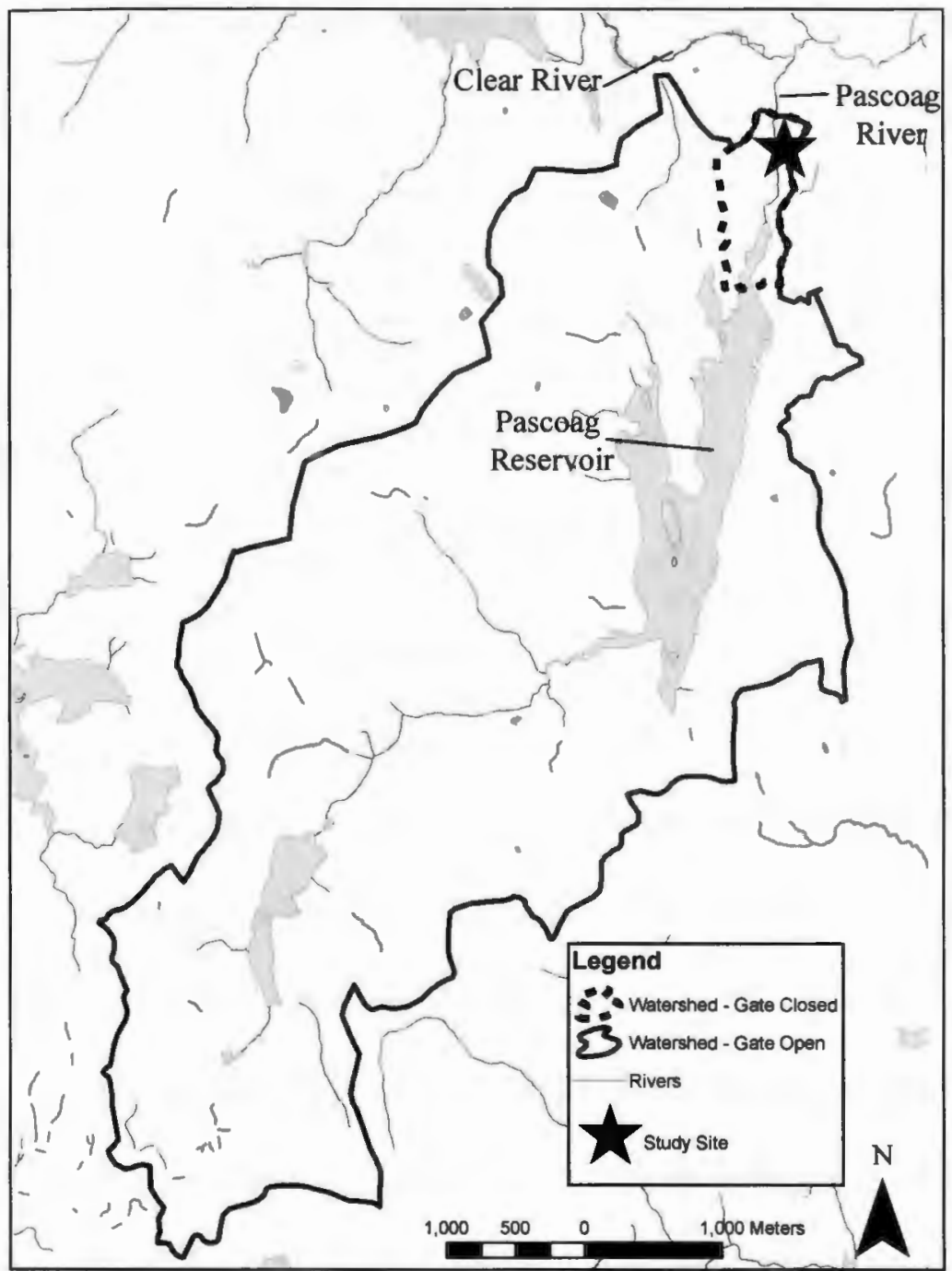

Figure 4. Watershed for Pascoag River. Watershed area is $22.6 \mathrm{~km}^{2}$ when the gate is open and decreases to $0.56 \mathrm{~km}^{2}$ when the gate is shut.

\subsubsection{Surface-Water Hydrology}

The Pascoag River is a low-order river in the Clear River Subbasin of the

Blackstone River Basin (Barlow 2003). The river begins at the Pascoag Reservoir and flows $1.37 \mathrm{~km}$ through Pascoag center prior to the confluence with the Clear River (Table 1). The watershed above the study site is $22.6 \mathrm{~km}^{2}$ and is primarily forested (Figure 4). A water-powered factory once existed at the study site but was destroyed in the 1960s. In order to maximize river power, the river channel was straightened, 
Table 1. Watershed and river specifics for Pascoag River.

\begin{tabular}{|l|c|}
\hline \multicolumn{2}{|c|}{ Watershed Information } \\
\hline Area $\left(\mathrm{km}^{2}\right)$ & 22.6 \\
River length (km) & 1.37 \\
Gradient (m/m) & 0.015 \\
\hline \multicolumn{2}{|c|}{ Study Site Information } \\
\hline Reach length (m) & 183 \\
Approx. River Width (m) & 3.5 \\
Approx. River Depth (m) & $0.1-1.5$ \\
Width/Depth Ratio & $2.3-3.5$ \\
Approx. Channel Depth (m) & $2-3$ \\
Sinuosity (m/m) & 1.1 \\
Gradient (m/m) & 0.002 \\
Floodplain Width (m) & $35-45$ \\
River Stage Range (m) & 1.2 \\
Discharge Range (m $\left.{ }^{3} / \mathrm{sec}\right)$ & $0.03-7.7$ \\
\hline
\end{tabular}

deepened, and lined with stone to create a race. A small retention pond was located behind a small earthen dam with a spillway that discharged water through the modified channel (Figure 2). At the study site, the channel is 3 to $4 \mathrm{~m}$ wide, between 2 and $3 \mathrm{~m}$ deep, and has a gentle gradient $(0.002 \mathrm{~m} / \mathrm{m})$ below the earthen dam. The riverbed contains large amounts of organic and manmade debris, including piles of bricks and portions of collapsed channel. Fine-grained sediment and larger rounded clasts are as not common in this channel as in typical river channels.

Pascoag Reservoir (also known as Echo Lake) has a total area of $1.41 \mathrm{~km}^{2}$, and average and maximum depths of 3.2 and $5.8 \mathrm{~m}$, respectively (Figure 4) (USEPA 2007; Plouffe pers. comm. 2006). There is a large upper and a small lower reservoir separated by an earthen dam with an average head difference of $4 \mathrm{~m}$. Unlike most reservoirs, the level of Pascoag Reservoir is low during the winter and high during the summer to provide for aquatic recreation. Reservoir level is maintained by the Pascoag Reservoir Association and is controlled by a sluice gate that releases water 
through a discharge pipe in the center of the dam. Large gate openings correspond to high discharge with a $25 \mathrm{~cm}$ gate opening estimated to yield a discharge of $1.4 \mathrm{~m}^{3} / \mathrm{sec}$ (Plouffe pers. comm. 2006). The gate is usually opened in October to drain the reservoir and closed in March to raise it approximately $1.5 \mathrm{~m}$ to its summer level. Additional gate adjustments are made in response to individual storm events. Discharge from upper Pascoag Reservoir also occurs over an overflow spillway that becomes active when the reservoir level reaches $2.8 \mathrm{~m}$ (above an arbitrary datum). When the gate is closed, the watershed area of the Pascoag River above the study site is reduced from $22.6 \mathrm{~km}^{2}$ to $0.56 \mathrm{~km}^{2}$ with high residential landuse and a considerable amount of impervious surfaces (Figure 4).

Discharge in the Pascoag River is therefore highly variable due to episodic gate adjustments and rapid response to stormflow. Sustained discharge in the river ranges from near zero in the summer to over $1.5 \mathrm{~m}^{3} / \mathrm{sec}$ during the winter, with stormflow discharges of up to $7.0 \mathrm{~m}^{3} / \mathrm{sec}$. River stage rise and stormflow is typically confined to the steeply walled channel; however, overbank flooding can occur. Stormflow discharge is flashy with peak and recession occurring rapidly. Changes in discharge related to gate adjustments at Pascoag Reservoir also occur rapidly and can increase or decrease river stage by more than $0.5 \mathrm{~m}$ in minutes. Prior work has also shown that the river channel is hydraulically well-connected to the aquifer with river stage driven water table fluctuations propagating through the aquifer within minutes to a distance of at least $30 \mathrm{~m}$ from the channel (Allen and Boving 2006). 


\subsubsection{Hydrogeology}

The hydraulic gradient is relatively steep between the source zone and the floodplain due to steeper surface and bedrock topography, with gradients of approximately $0.06 \mathrm{~m} / \mathrm{m}$ from the source zone to the floodplain and $0.01 \mathrm{~m} / \mathrm{m}$ or less within the floodplain. There are no nested multi-level wells in the source zone to identify vertical gradients; however, a downward gradient is assumed. Ground-water flow to the floodplain occurs through bedrock fractures and through the sand and gravel aquifer. Limited historical data from nested multi-level wells in the floodplain indicate an upward vertical hydraulic gradient steepening closer to the river. The water table depth is generally between 1 and $2 \mathrm{~m}$ below ground surface throughout the floodplain; however, during some periods it may be less than $1 \mathrm{~m}$ below the surface (Figure 3).

\subsubsection{Ground-water/Surface-Water Interaction}

No prior studies have been conducted at the site to determine if the river reach is gaining or losing. Attempts to determine vertical gradients using riverbed piezometers were unsuccessful due to loss during high discharge in the winter or by tampering. Given the presence of contaminant discharge in sections of the river reach and a general model of gaining rivers in the northeast, it is believed that this river reach is predominantly gaining (Allen and Boving 2006; Job and Simons 1996; RIDEM unpublished data; Winter et al. 1998). 


\subsection{Contaminant Fate and Transport}

The current distribution of contaminants outside of the source zone has been significantly affected by induced ground-water flow from pumping of the former supply well (Figure 5). It is believed that this has created a secondary contaminant source zone within bedrock fractures and is providing a significant proportion of current contamination (Allen and Boving 2006). As a result, contaminated ground water may flow between the source zone and the floodplain by traveling northward through bedrock fractures until discharging into the adjacent sand and gravel aquifer at depth. A second possible flowpath suggests that the contaminant plume discharges from the bedrock and migrates towards the river closer to the source zone and then follows the buried channel introduced above. Regardless of the exact ground-water flowpath, bedrock fractures, former channels, topography, and the river combine to control ground-water flow and contaminant transport to the river.

Initially, the contaminant plume, consisting of MTBE, benzene, toluene, ethylbenzene, xylene (collectively termed BTEX) and other gasoline compounds, extended north-northeast from the source zone in both the bedrock and the overlying unconsolidated sand and gravel aquifer. Maximum dissolved phase MTBE concentrations were over $1,000 \mathrm{mg} / \mathrm{L}$ and low-level contamination of $0.04 \mathrm{mg} / \mathrm{L}$ extended over an area of $80,000 \mathrm{~m}^{2}$ (RIDEM unpublished data). After the supply well was shut down, the water table returned to a natural gradient consistent with local topography and surface-water hydrology, shifting the contaminant plume orientation to a north-northwest flowpath. As a consequence, the plume began to discharge to the Pascoag River which flows north along the western extent of the site. 


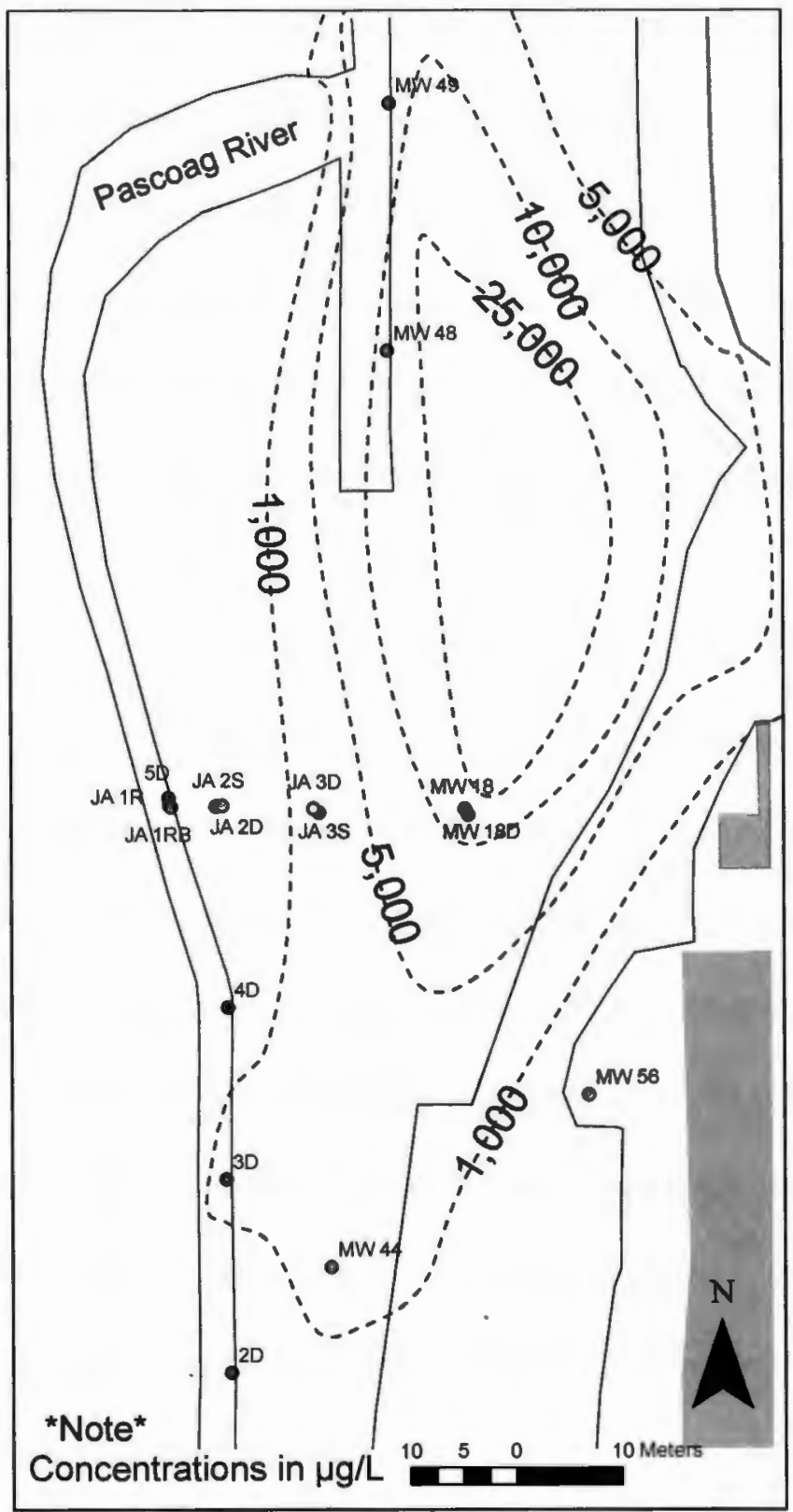

Figure 5. MTBE contaminant distribution at the start of this study in early 2006 . Distribution is based on available monitoring well data. The highest contamination resides in the area between MW 18 \& MW 18D and MW 48 where focused discharge to the dead-end channel occurs. Discharge to the river channel also occurs to the river upstream near 3D. These two discharge locations result in low MTBE concentrations in the river periodically throughout the year.

Onsite remediation has significantly reduced contaminant concentrations in the source zone; however, the plume continues to discharge to the river and impact surface-water quality along this reach. The early 2006 distribution of MTBE in the floodplain from ground-water monitoring is shown in Figure 5. Source zone MTBE 
concentrations have been reduced to less than $100 \mu \mathrm{g} / \mathrm{L}$, while concentrations near the river remain close to $10,000 \mu \mathrm{g} / \mathrm{L}$ (RIDEM unpublished data). BTEX concentrations still exceed $2,000 \mu \mathrm{g} / \mathrm{L}$ for individual compounds in the source zone and along the river (RIDEM unpublished data). As described by Allen and Boving (2006), multilevel wells and contaminant distributions in the study area indicate that contaminants are discharged from the sloping bedrock into the adjacent sand and gravel aquifer (Figure 3).

Significant discharge of contaminated ground water to the river occurs downstream of the study site near MW 48 in a short stretch of channel that has been partially filled in and is not part of the active river channel (Figure 5). Discharge of contaminated ground water is evident by the presence of gasoline odor, orange biofilm, gasoline sheen on the surface water, and MTBE surface-water concentrations up to $2,000 \mu \mathrm{g} / \mathrm{L}$ (RIDEM unpublished data). A second area of discharge is located in the main river channel near 3D upstream from the study site closer to the source zone (Figure 5). Discharge here was identified by an MTBE concentration in the riverbed of up to $2,000 \mu \mathrm{g} / \mathrm{L}$ which is diluted rapidly in the river channel resulting in a low river concentration (RIDEM unpublished data). 


\section{METHODS}

Research methods and wellfield design were chosen in order to fulfill several objectives including, 1) to identify spatial and temporal changes in the vertical and horizontal gradients between individual wells and between the aquifer and the river, 2) to identify spatial and temporal changes in MTBE and BTEX concentrations, and 3) to identify and correlate the above observations with river stage fluctuations.

Table 2. Well construction and well location information.

(Unk = Unknown and NA $=$ Not applicable)

\begin{tabular}{|c|c|c|c|c|c|c|c|c|c|c|}
\hline Well & $\begin{array}{c}\text { Installation } \\
\text { Date }\end{array}$ & Location & $\begin{array}{c}\text { Top of } \\
\text { Casing } \\
\text { Elevation } \\
(\mathrm{m})\end{array}$ & $\begin{array}{c}\text { Surface } \\
\text { Elevation } \\
(\mathrm{m})\end{array}$ & $\begin{array}{c}\text { Well Depth } \\
\text { BGS or } \\
\text { Riverbed } \\
(\mathrm{m})\end{array}$ & $\begin{array}{c}\text { Depth to } \\
\text { I.D. } \\
(\mathrm{cm})\end{array}$ & $\begin{array}{c}\text { Refusal/ } \\
\text { Bedrock } \\
(\mathrm{m})\end{array}$ & $\begin{array}{c}\text { Screen } \\
\text { Length } \\
(\mathrm{m})\end{array}$ & $\begin{array}{c}\text { Distance } \\
\text { From } \\
\text { River } \\
(\mathrm{m})\end{array}$ & $\begin{array}{c}\mathrm{K} \\
(\mathrm{cm} / \mathrm{sec})\end{array}$ \\
\hline JA 2S & $2 / 2 / 2006$ & Aquifer & 112.28 & 111.98 & 3.05 & 2.54 & 7.32 & 0.30 & 3.1 & $6.4 \mathrm{E}-03$ \\
\hline JA 2D & $2 / 2 / 2006$ & Aquifer & 112.37 & 112.07 & 6.10 & 2.54 & 7.32 & 0.30 & 3.1 & $7.3 \mathrm{E}-04$ \\
\hline JA 3S & $1 / 19 / 2006$ & Aquifer & 112.33 & 112.03 & 3.05 & 2.54 & 6.70 & 0.30 & 14.3 & $7.7 \mathrm{E}-03$ \\
\hline JA 3D & $1 / 19 / 2006$ & Aquifer & 112.33 & 112.03 & 6.10 & 2.54 & 6.70 & 0.30 & 14.3 & $3.5 \mathrm{E}-04$ \\
\hline MW 18 & $2 / 2002$ & Aquifer & 112.49 & 112.19 & 4.27 & 2.54 & 7.62 & 3.05 & 27.4 & $4.6 \mathrm{E}-03$ \\
\hline MW 18D & $8 / 2004$ & Aquifer & 112.56 & 112.26 & 7.02 & 2.54 & 7.62 & 6.10 & 27.4 & $4.5 \mathrm{E}-04$ \\
\hline JA 1RB & $8 / 26 / 2006$ & Riverbed & 111.97 & NA & 0.76 & 2.54 & NA & 0.30 & NA & Unk \\
\hline JA 1R & $8 / 26 / 2006$ & River & 111.94 & NA & NA & 1.90 & NA & 1.04 & NA & NA \\
\hline MW 44 & $6 / 2004$ & Aquifer & 112.90 & 112.20 & 2.35 & 2.54 & Unk & 1.50 & 7.6 & $3.9 \mathrm{E}-03$ \\
\hline MW 48 & $7 / 2004$ & Riverbed & 111.25 & NA & Unk & 2.54 & Unk & Unk & NA & Unk \\
\hline MW 56 & $8 / 2004$ & Aquifer & 112.97 & 112.82 & 2.29 & 2.54 & Unk & 1.50 & 32 & $8.3 \mathrm{E}-04$ \\
\hline ID & $3 / 31 / 2006$ & Riverbed & Unk & NA & 0.72 & 2.54 & Unk & 0.30 & NA & Unk \\
\hline 2D & $3 / 31 / 2006$ & Riverbed & Unk & NA & 0.61 & 2.54 & Unk & 0.30 & NA & Unk \\
\hline 3D & $3 / 31 / 2006$ & Riverbed & Unk & NA & 0.68 & 2.54 & Unk & 0.30 & NA & Unk \\
\hline 4D & $3 / 31 / 2006$ & Riverbed & 112.03 & 111.28 & 0.84 & 2.54 & Unk & 0.30 & NA & Unk \\
\hline 5D & $3 / 31 / 2006$ & Riverbed & 112.27 & 111.81 & 1.14 & 2.54 & Unk & 0.30 & NA & $5.6 \mathrm{E}-04$ \\
\hline 6D & $3 / 31 / 2006$ & Riverbed & Unk & NA & 0.98 & 2.54 & Unk & 0.30 & NA & Unk \\
\hline
\end{tabular}

In order to accomplish the goals presented above, a well transect was installed perpendicular to the river approximately $550 \mathrm{~m}$ downgradient from the source zone.

The wells monitored included five preexisting monitoring wells and 12 wells installed specifically for this project (Table 2 and Figure 6). Three surface water locations were also monitored to determine inflowing river chemistry upstream of $2 \mathrm{D}$, downstream at MW 49, and at JA 1R. Except for JA 1RB, JA 1R, and the riverbed wells which were installed by the hand, all wells were installed by RIDEM using a Geoprobe $($ Well 


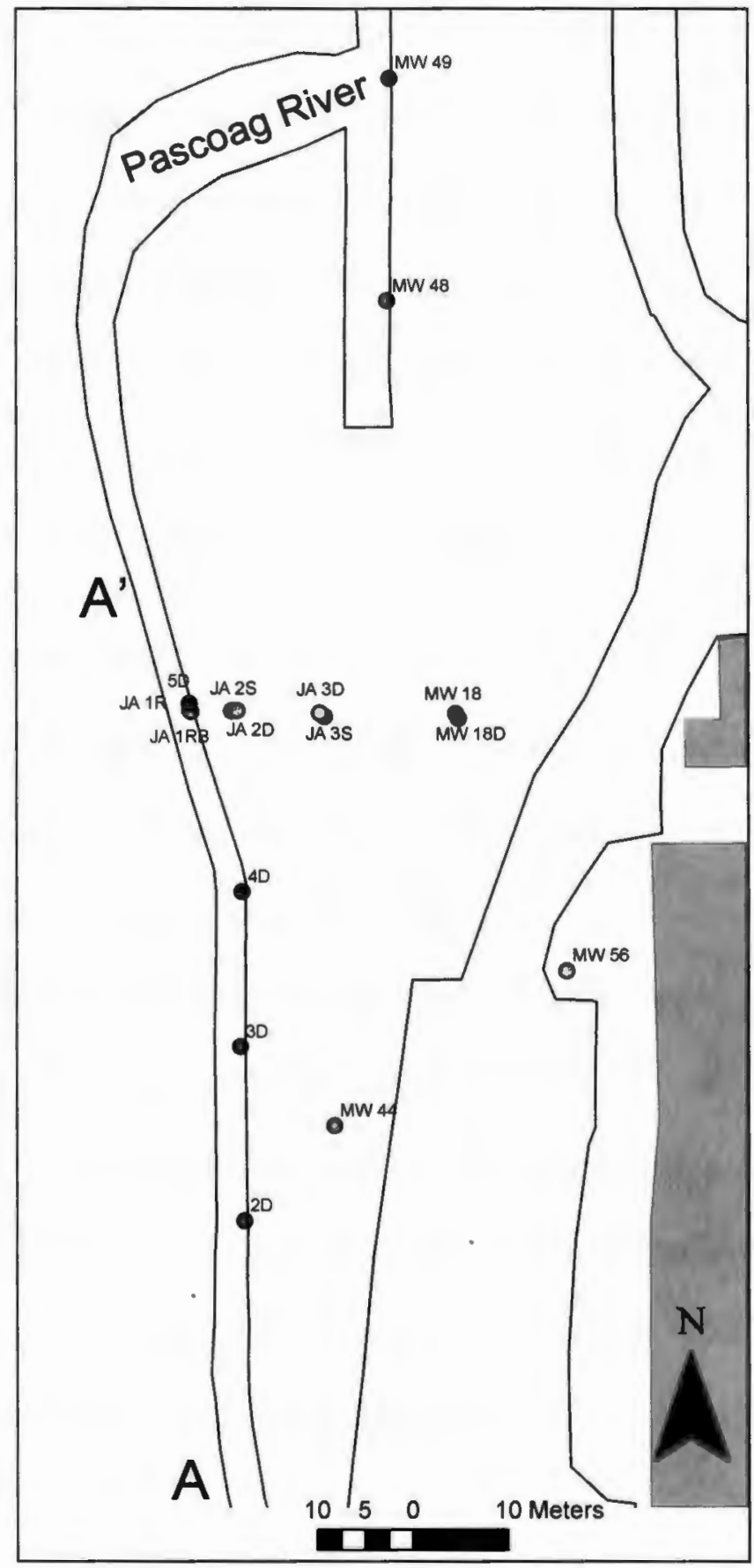

Figure 6. Monitoring well and riverbed well locations used in this study. Three surface water locations were also sampled, upstream near 2D, at JA 1R, and downstream near MW 49. A and $A^{\prime}$ correspond to a conceptual riverbed cross section showing channel morphology and is discussed further in Figure 18.

casing elevations were surveyed to obtain absolute water table elevations. Complete well installation and surveying methods are provided in the Appendix II. 
Wells were sampled approximately every two weeks unless specific events such as precipitation or gate events warranted more frequent sampling. Periods of less frequent sampling also occurred due to relatively stable conditions (i.e. dry periods). Continuous measurements of hydraulic head and temperature were collected in several wells for the entire or part of study period. The following is a summary of the field data acquisition methods. Additional information regarding sampling, field instruments, slug tests, and river discharge is available in Appendix II.

\subsubsection{Sampling and Field Parameters}

Well purging and sampling was performed using a peristaltic pump utilizing EPA low-flow ground-water sampling principles when possible (Puls and Barcelona 1996). In order to maintain pump circulation, the lowest pump rate used was 150 to 250 $\mathrm{mL} / \mathrm{min}$, depending on the well depth. Initially wells were purged until the field parameters, dissolved oxygen (DO), $\mathrm{pH}$, electrical conductivity (EC), and temperature stabilized. After several months, the time required for parameter stabilization grew longer probably due to aquifer stratification associated with precipitation, or possibly downward flow along the casing. The method, therefore, was modified to include the monitoring of pumping time to establish a consistent ground-water contribution zone for each sampling events.

Field measurements of DO, $\mathrm{pH}, \mathrm{EC}$ and temperature were recorded after well purging and satisfactory stabilization. Field instruments were calibrated and operated according to manufacturers specifications. VOC samples were taken by slowly filling duplicate $40 \mathrm{~mL}$ VOA vials. The vials were preserved with four drops of $6 \mathrm{~N}$ hydrochloric acid with zero headspace and stored at approximately $4^{\circ} \mathrm{C}$ until analysis. 
Ground-water and surface-water samples for ion analysis were collected in $125 \mathrm{~mL}$ HDPE bottles. The unpreserved samples were stored at $4^{\circ} \mathrm{C}$ prior to filtering and analysis.

\subsubsection{Water Table Measurements}

Continuous measurements were collected with In-situ $($ dataloggers installed in five wells. For quality control purposes and in order to convert relative elevation changes to water table elevations, manual measurements were collected when dataloggers were installed in wells and when they were removed.

\subsubsection{Temperature Measurements}

Both manual and continuous measurements were also collected to monitor temperature variation in each well. Manual measurements were collected during each sampling event while continuous measurements were collected by datalogger temperature sensors and by Thermochron iButtons $\otimes$ (Dallas Semiconductor). The iButtons were placed in small plastic bags, attached to pump tubing or cable, and placed along the screened interval.

\subsection{Laboratory Methods}

\subsubsection{Volatile Organics Analysis}

Volatile organic analysis (VOA) samples were stored at $4^{\circ} \mathrm{C}$ and allowed to equilibrate to room temperature prior to preparation and analysis by a purgeable volatiles method similar to EPA Method 624. Most samples were analyzed within the EPA specified holding time of 14 days; however, several samples were analyzed 
outside of this holding time but within 18 days. It is not believed that this significantly affected the results.

VOA sample introduction was performed with a OI Analytical 4660 purge and trap and analysis completed using a Shimadzu GC-17A gas chromatograph equipped with QP5000 mass spectrometer (GC/MS). A 6-point external calibration of target compounds (Table 3) was performed from 2 to $160 \mu \mathrm{g} / \mathrm{L}$ and samples were spiked

Table 3. Target VOCs and minimum detection limits (MDLs).

\begin{tabular}{|l|c|}
\hline $\begin{array}{c}\text { Target } \\
\text { Compound }\end{array}$ & $\begin{array}{c}\text { Minimum } \\
\text { Detection Limit } \\
(\mu \mathrm{g} / \mathrm{L})\end{array}$ \\
\hline MTBE & 0.7 \\
Benzene & 0.7 \\
Toluene & 1.2 \\
Ethylbenzene & 1.4 \\
m-Xylene and p- & 0.4 \\
Xylene & 1.0 \\
\hline o-Xylene & \\
\hline
\end{tabular}

with 4-Bromofluorobenzene (BFB) as a surrogate compound. A full description of the GC/MS operating parameters and methods can be found in Appendix II. Average BFB surrogate recovery for all analyses performed was $95.6 \%$ with a standard deviation of $6.6 \%(n=350)$. Average MTBE calibration verification recovery was $99.3 \%$ with a standard deviation of $7.2 \%(n=124)$. A method blank was prepared and analyzed for every batch of samples run. Due to the high number of dilutions required, laboratory duplicates were evaluated on diluted samples rather than by rerunning. 


\subsubsection{Inorganic Analysis}

Samples for anion and cations were stored at $4^{\circ} \mathrm{C}$ and filtered with a $0.45 \mu \mathrm{m}$ syringe filter prior to analysis. Anion samples were not analyzed within the Method 300.0 recommended holding time of 28 days or 48 hours (for nitrate and phosphate). The holding time for cations is 6 months and was fulfilled by a limited number of analyses.

Both anions and cations were analyzed on a Dionex DX-120 ion chromatograph. Target ions were chloride, nitrate, phosphate, sulfate, sodium, potassium, magnesium, and calcium. Additional analytical procedures and MDLs are in Appendix II. 


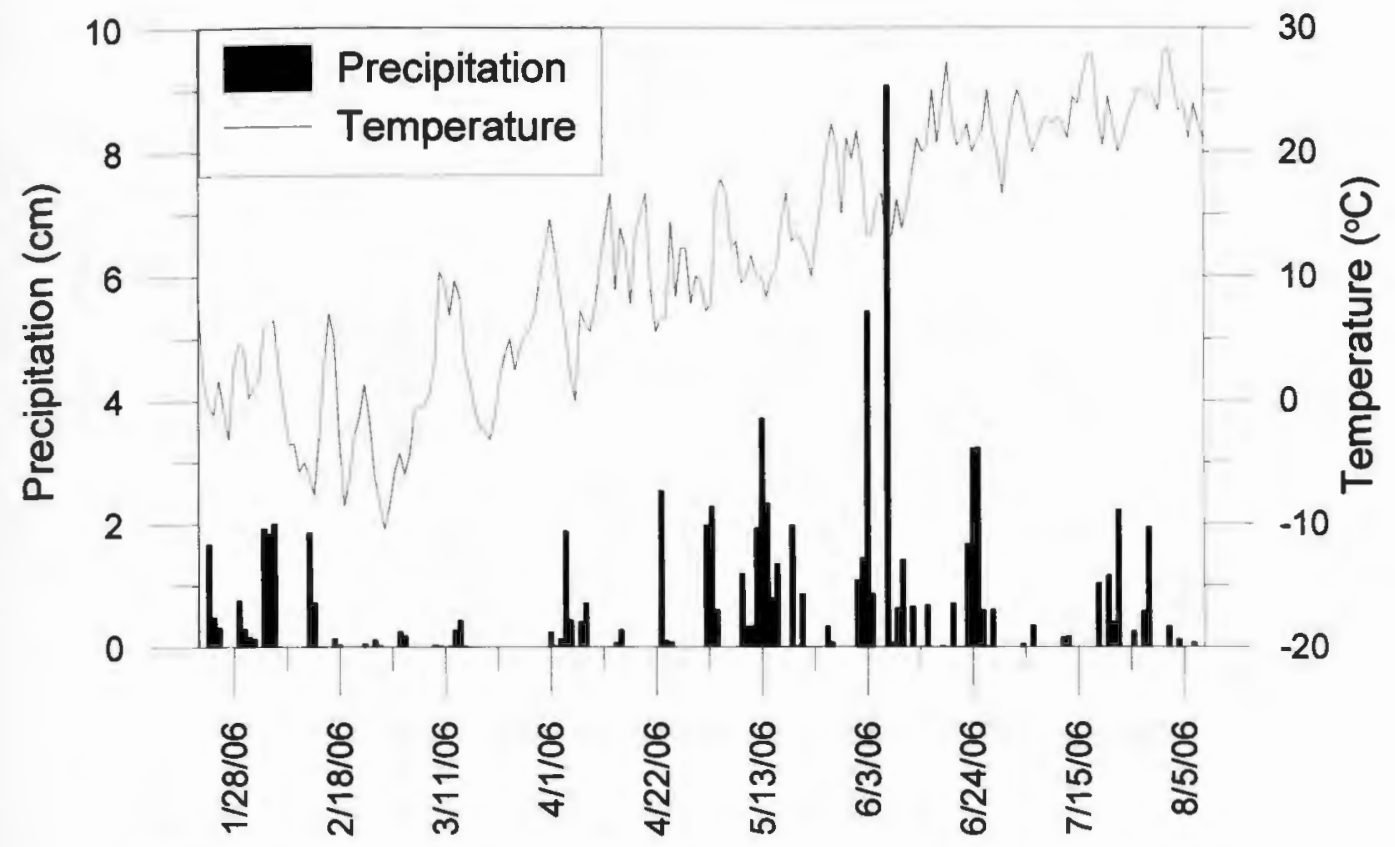

Figure 7. Precipitation and average temperature measured during this study.

\section{RESULTS}

\subsection{Precipitation and Temperature}

Between January 21 and August 9, 2006 a total of $81.3 \mathrm{~cm}$ of precipitation was measured over several extended periods (Figure 7). Refer to Appendix I for local historical weather and for measurement station locations. The average monthly temperature was similar to historical averages with a low in February $\left(-2^{\circ} \mathrm{C}\right)$ and the high in July $\left(23^{\circ} \mathrm{C}\right)$. Daily temperature ranges were dependent upon precipitation, with low diurnal variation occurring during storms.

\subsection{Reservoir Discharge and River Stage}

Pascoag Reservoir water level and reservoir discharge to Pascoag River varied significantly related to gate adjustments driven by precipitation and reservoir levels (Figure 8). In response to these adjustments, river stage varied by approximately 1.0 $\mathrm{m}$ for the Pascoag River at the study site (Figure 9). Gate adjustments at Pascoag 


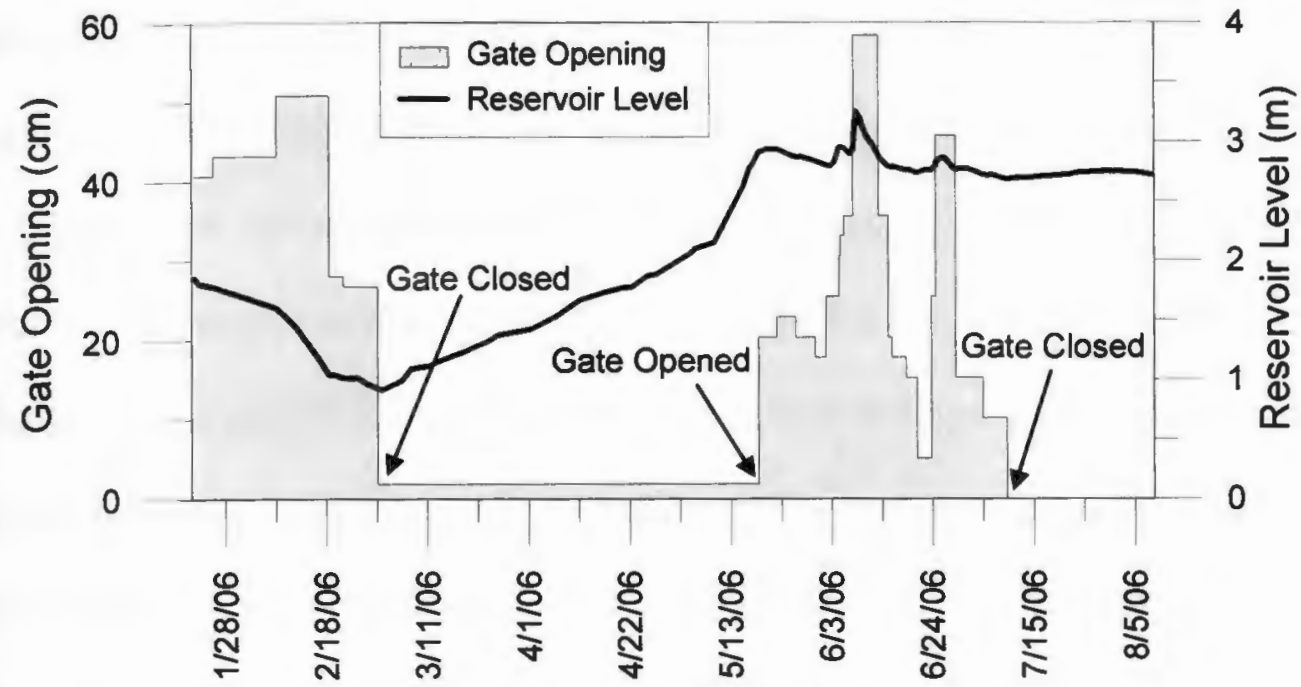

Figure 8. Pascoag Reservoir water level and sluice gate opening.

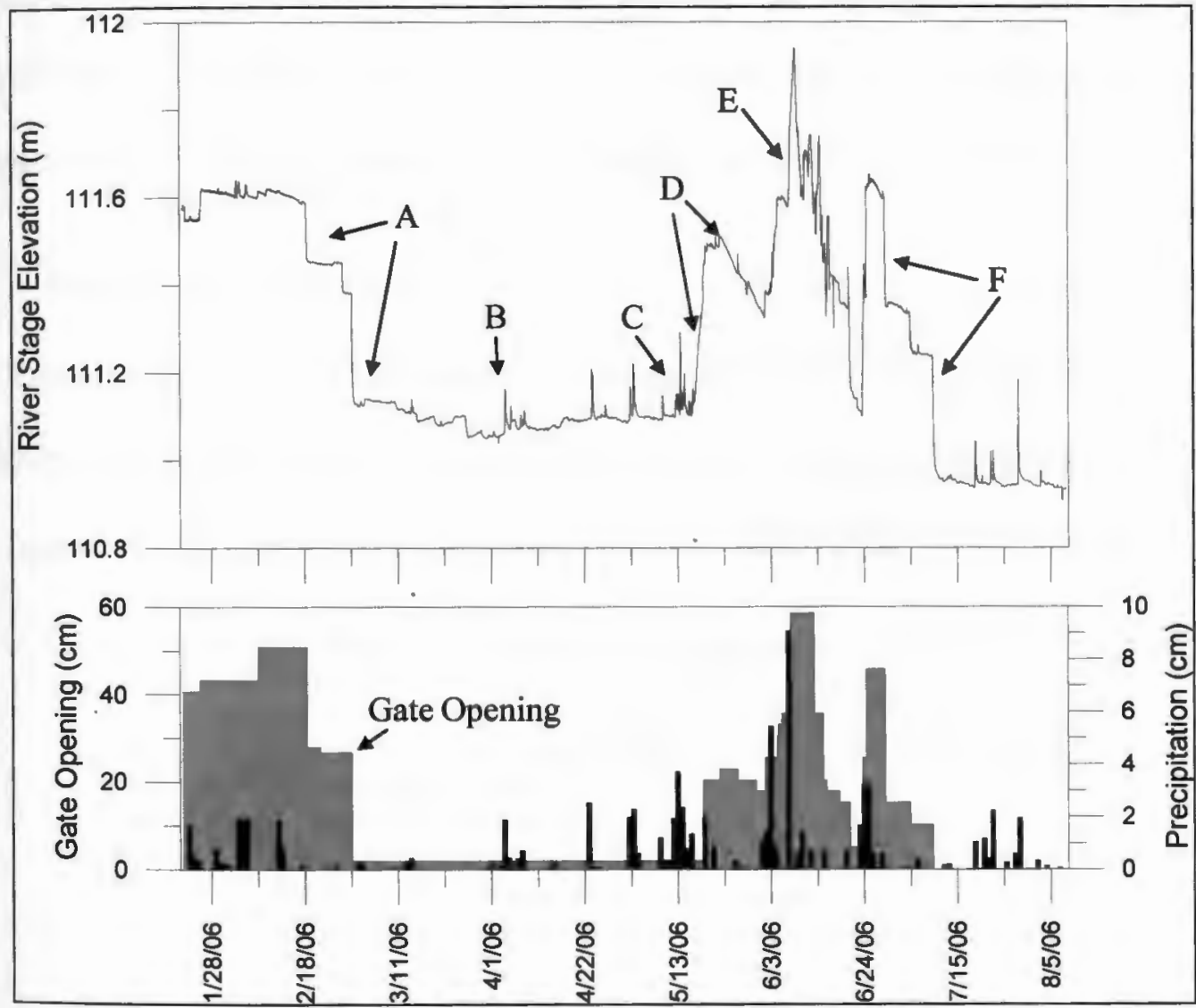

Figure 9. River stage hydrograph and controlling factors, precipitation and gate opening.

Hydrograph correlation with reservoir gate opening confirms that this is the primary factor controlling river stage $(A \& F)$. During periods where the gate is closed and river stage is low (B),

fluctuations, although infrequent are only caused by individual precipitation events and river stage effects are short-term $(C)$. The influence of the reservoir spillway $(D)$ results in a slow increase or decrease in river stage. When the river stage and precipitation are high, bankfull and flooding are common $(E)$. 
Reservoir immediately impacted river discharge and river stage, indicated by $\mathrm{A}$ and $\mathrm{F}$ on the figure. When river stage is low and the weather is dry, variability is also low (B). During these periods, individual precipitation events do not have a significant impact on river stage, but rather their effect is short-term (C). Fluctuating spillway discharge creates gradual increases and decreases in river stage (D) as the reservoir level rises and falls in response to precipitation. When the reservoir gate is open, river stage response to precipitation events is overwhelmed by the discharge from the reservoir (E). Two large precipitation events in June resulted in high reservoir discharge to Pascoag River and river stage increased rapidly to flood stage. During this event, overbank flooding occurred at the site and submerged the monitoring equipment forcing river stage estimation from the top of the well casing.

\subsection{Water-Table Elevations}

Water table elevations in the study area range from approximately $110.9 \mathrm{~m}$ to $112.6 \mathrm{~m}$ with higher minimum and maximum heads at the upgradient wells closer to the source zone (Table 4 and Figure 10). The water table quickly responded to

Table 4. Water table monitoring information and elevations.

\begin{tabular}{|l|c|c|c|c|c|c|}
\hline \multirow{2}{*}{ Well } & \multicolumn{2}{|c|}{ Monitoring } & \multicolumn{4}{c|}{ Hydraulic Head (m) } \\
\cline { 2 - 7 } & Type & Begin Date & Minimum & Maximum & Average & Variability \\
\hline River Stage & Continuous & $1 / 21 / 2006$ & 110.91 & 111.94 & 111.28 & 1.03 \\
JA 1RB & Manual & $2 / 2 / 2006$ & 110.93 & 111.97 & 111.30 & 1.04 \\
JA 2S & Continuous & $2 / 2 / 2006$ & 110.92 & 112.03 & 111.23 & 1.11 \\
JA 2D & Continuous & $2 / 2 / 2006$ & 110.95 & 112.08 & 111.25 & 1.13 \\
JA 3S & Manual & $1 / 21 / 2006$ & 110.93 & 112.01 & 111.31 & 1.08 \\
JA 3D & Continuous & $1 / 21 / 2006$ & 110.95 & 112.08 & 111.32 & 1.13 \\
MW 18 & Manual & $1 / 21 / 2006$ & 110.95 & 112.03 & 111.36 & 1.08 \\
MW 18D & Continuous & $1 / 21 / 2006$ & 111.21 & 112.35 & 111.58 & 1.14 \\
MW 44 & Manual & $1 / 24 / 2006$ & 111.10 & 112.29 & 111.50 & 1.19 \\
MW 56 & Manual & $2 / 2 / 2006$ & 111.26 & 112.55 & 111.71 & 1.29 \\
4D & Manual & $4 / 21 / 2006$ & 110.87 & 112.03 & 111.27 & 1.16 \\
5D & Manual & $5 / 20 / 2006$ & 110.67 & 111.70 & 111.08 & 1.03 \\
\hline
\end{tabular}




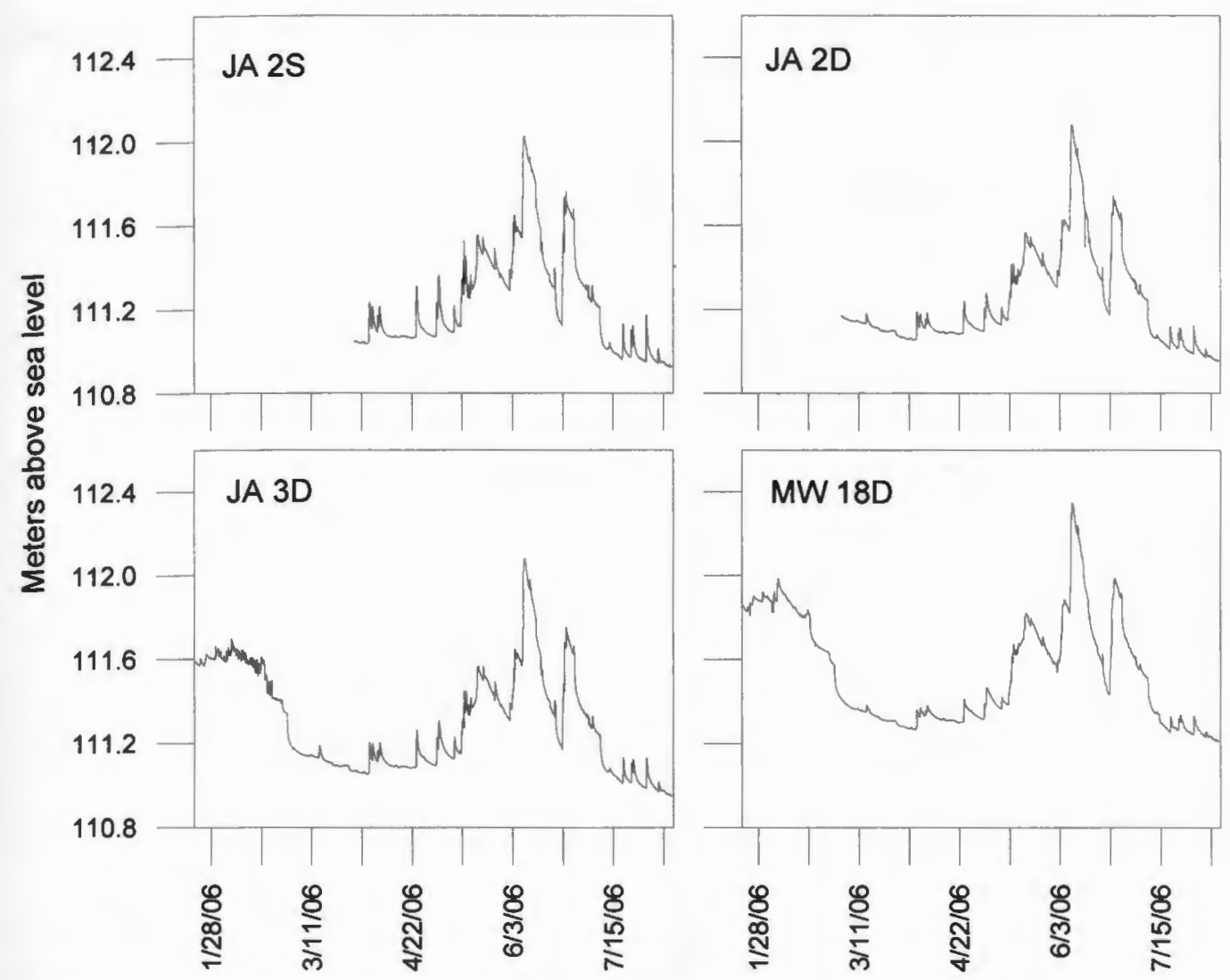

Figure 10. Water table elevations obtained by dataloggers. Wells JA 2S and JA 2D and located 3 $\mathrm{m}$ from river channel, while JA 3D and MW 18D are $14 \mathrm{~m}$ and $27 \mathrm{~m}$, respectively. Complete well construction information is available in Table 2.

fluctuations in river stage. This indicates that the river is hydraulically well connected to the aquifer and the dominant process controlling the position of the floodplain water table is river stage. During precipitation events and following gate closures, river stage elevation was significantly lower than most water table elevations.

\subsection{Hydraulic Gradient}

Overall ground-water flow and hydraulic gradient in the floodplain are directed toward the river both horizontally and vertically but vary considerably spatially and temporally (Table 5). Results indicate that immediately adjacent to the river channel between JA $2 \mathrm{~S}$ and the river, flow direction is much more variable and reverses 
Table 5. Horizontal and vertical hydraulic gradient realtionships between several wells in the floodplain and between the floodplain and the river.

\begin{tabular}{|c|c|c|c|c|}
\hline & \multicolumn{4}{|c|}{ Horizontal Gradient (m/m) } \\
\hline Well & Minimum & Maximum & Average & Variability \\
\hline MW 56 - MW 44 & 0.006 & 0.011 & 0.008 & 0.006 \\
MW 44 - MW 18 & 0.002 & 0.006 & 0.004 & 0.004 \\
MW 56 - MW 18 & 0.009 & 0.018 & 0.013 & 0.009 \\
JA 3S - JA 2S & 0.000 & 0.002 & 0.001 & 0.002 \\
JA 3D - JA 2D & -0.001 & 0.001 & 0.000 & 0.002 \\
\hline & \multicolumn{4}{|c|}{ Vertical Gradient (m/m) } \\
& \multicolumn{4}{|c|}{} \\
\cline { 2 - 5 } & Minimum & Maximum & Average & Variability \\
\hline JA 3D - JA 2S & 0.000 & 0.005 & 0.003 & 0.005 \\
JA 2D - JA 2S & 0.000 & 0.017 & 0.009 & 0.017 \\
JA 2D - JA 3S & -0.001 & 0.003 & 0.001 & 0.004 \\
JA 3D - JA 3S & -0.002 & 0.013 & 0.006 & 0.015 \\
JA 2D - River & -0.003 & 0.017 & 0.005 & 0.021 \\
JA 2S - River & -0.011 & 0.018 & 0.001 & 0.030 \\
JA 1RB - River & -0.008 & 0.022 & 0.004 & 0.030 \\
\hline
\end{tabular}
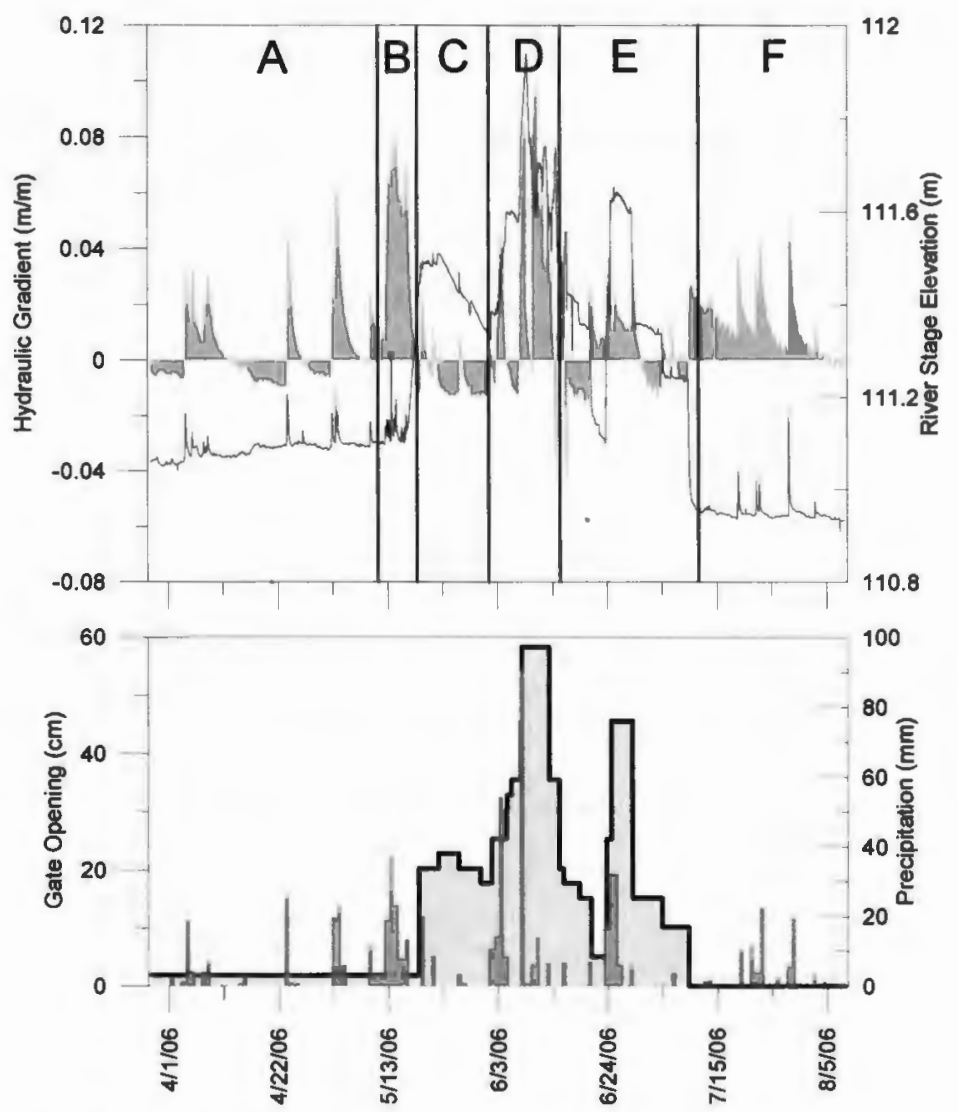

Figure 11. Hydraulic gradient between JA 2S and the river indicating frequent gradient fluctuations and reversals. The river at this location is typically slightly losing except for during precipitation and gate adjustments. Figures are available in Appendix III for the gradient from JA 2D to 2S and JA 3D to 2D. Letters indicate distinct periods characterized by individual aquifer responses to be discussed later and are not related to those in Figure 9. 
frequently (Figure 11). Losing river conditions tend to prevail during low-stage and dry periods while gaining conditions tend to occur when river stage is high and during precipitation events. Significant gradient reversal and steepening does not appear to occur between JA 3S \& JA 2S or JA 3D \& JA 2D (Appendix III) and instead the hydraulic gradient is flat resulting in flow nearly parallel to the river channel.

The vertical hydraulic gradient between JA 2D \& JA 2S and between JA 3D \& JA 3S was always upwards except after overbank flooding in June and the resultant flattening of the water table throughout the study area (Figure 12). There was

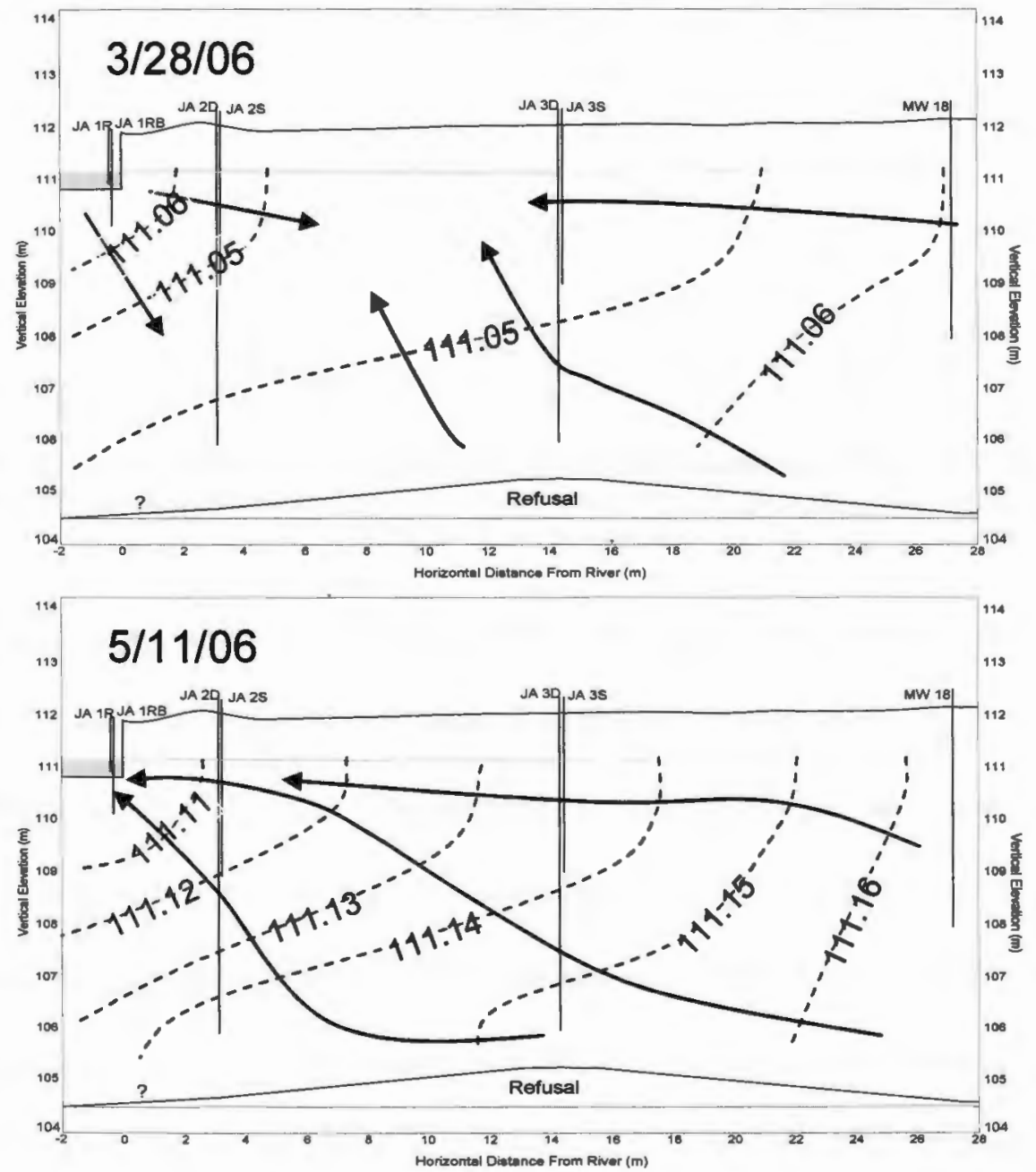

Figure 12. Generalized vertical gradient in the floodplain during losing period (3/28/06) and during gaining period (5/11/06). 
significant gradient variability with steeper vertical gradients being associated with precipitation and gate closures. The gradient between JA 2D \& JA 2S was steeper than between JA 3D \& JA 3S which suggests a greater amount of upward flow beneath the river (Appendix III). Both wells had the lowest sustained vertical gradients during the dry period in April when river stage was low.

Between wells MW 18, MW 44, and MW 56 in the upgradient floodplain, ground water consistently traveled toward the river, with MW 56 to MW 18 having the

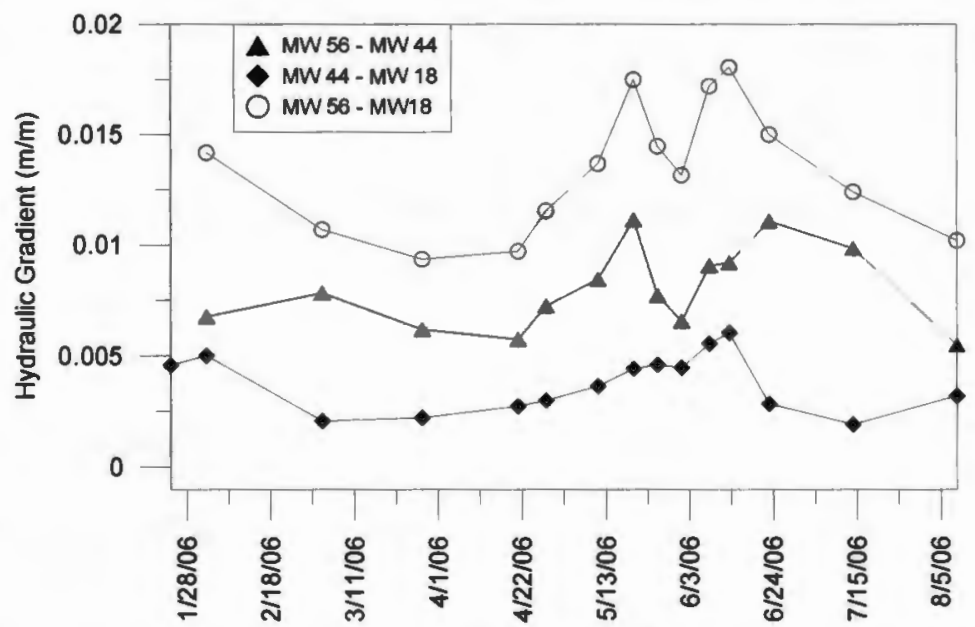

Figure 13. Hydraulic gradient in upgradient floodplain wells between MW 56, MW 44, and MW 18. Graph indicates increased hydraulic gradient when river stage is high and during periods of increased precipitation.

steepest average gradient and MW 44 to MW 18 the shallowest average gradient (Figure 13). There was significant temporal variability in the hydraulic relationships between the wells with steepening and shallowing of the gradients related to precipitation and river stage fluctuations. The relative gradients between these wells, however, remained similar indicating that flow direction did not change significantly, but rather only the magnitude of flow. Figure 14 illustrates the overall hydraulic gradient and general losing and gaining flow regimes in the floodplain 


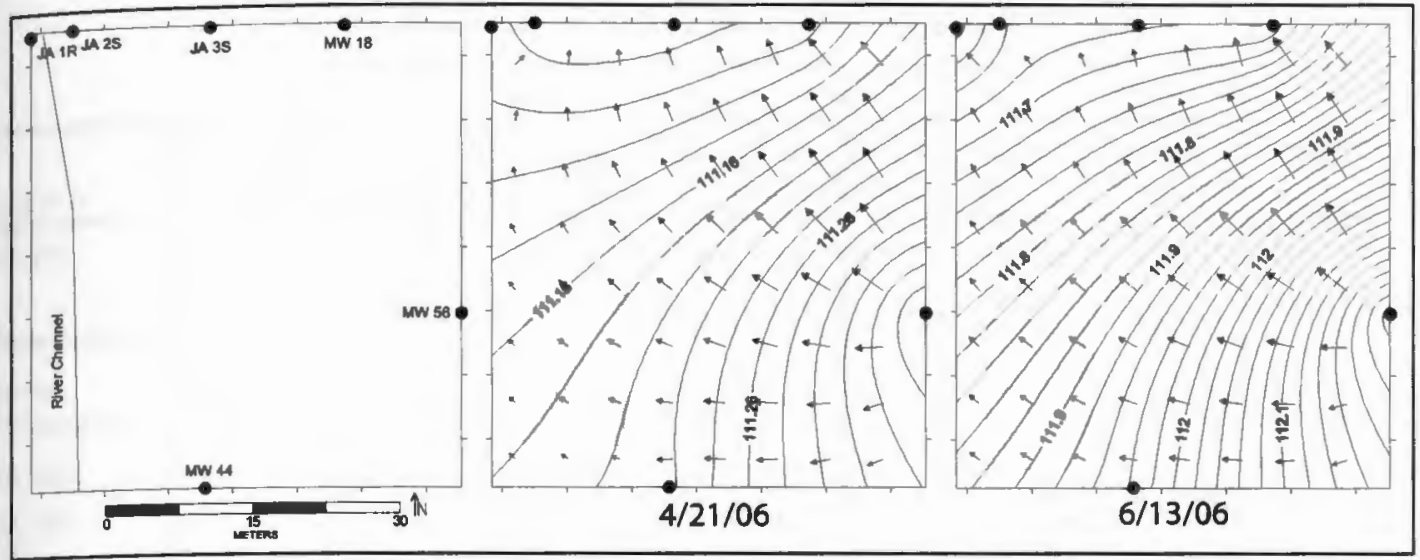

Figure 14. Floodplain ground-water flow regimes indicating flow in the floodplain towards the river. When the gradient is shallow, the river is slightly losing and ground-water flow can not overcome hyporheic exchange flow. During precipitation events and when the gradient steepens, the hyporheic flow is overcome and ground-water discharge occurs. A complete set of flow regimes for 13 sampling dates is available in Appendix III.

during a low-gradient losing period (April 21, 2006) and a high-gradient gaining period (June 13, 2006).

\subsection{Organic Chemistry}

\subsubsection{MTBE and BTEX}

Significant spatial and temporal variability in MTBE and BTEX concentrations were found during the study period (Table 6). Temporal variability in individual wells ranged up to an order of magnitude. Several wells responded similarly, typically related to depth and location. Most of the shallow wells were affected by the overbank flooding in June 2006 resulting in lower concentrations than other times, probably due to dilution. A complete set of results for all wells and individual compounds is provided in Appendix III.

Concentrations in JA 2D and JA 3D behaved similarly, with significant MTBE fluctuations of $2300 \mu \mathrm{g} / \mathrm{L}$ and $4700 \mu \mathrm{g} / \mathrm{L}$, respectively (Figure 15). BTEX concentrations also fluctuated but were considerably lower in magnitude. In 
Table 6. Summary of VOC analyses for MTBE and BTEX.

\begin{tabular}{|c|c|c|c|c|c|c|c|c|c|c|c|}
\hline \multirow[b]{2}{*}{ Location } & & \multicolumn{5}{|c|}{ MTBE } & \multicolumn{5}{|c|}{ BTEX } \\
\hline & $\mathrm{n}$ & $\begin{array}{r}\text { AVG } \\
(\mu \mathrm{g} / \mathrm{L}) \\
\end{array}$ & $\begin{array}{c}\text { STD DEV } \\
(\mu \mathrm{g} / \mathrm{L})\end{array}$ & $\begin{array}{l}\text { STD DEV } \\
\text { Relative \% }\end{array}$ & $\begin{array}{c}\mathrm{M} \mathbb{N} \\
(\mu \mathrm{g} / \mathrm{L}) \\
\end{array}$ & $\begin{array}{r}\mathrm{MAX} \\
(\mu \mathrm{g} / \mathrm{L}) \\
\end{array}$ & $\begin{array}{l}\text { AVG } \\
(\mu g / L) \\
\end{array}$ & $\begin{array}{c}\text { STD DEV } \\
(\mu \mathrm{g} / \mathrm{L})\end{array}$ & $\begin{array}{l}\text { STD DEV } \\
\text { Relative \% }\end{array}$ & $\begin{array}{c}\mathrm{MIN} \\
(\mu \mathrm{g} / \mathrm{L})\end{array}$ & $\begin{array}{l}\text { MAX } \\
(\mu g / L)\end{array}$ \\
\hline $\mathrm{JA} 1 \mathrm{R}$ & 16 & 0.5 & 0.8 & 160 & ND & 2.5 & ND & ND & NA & ND & ND \\
\hline River Upstream & 8 & ND & ND & NA & ND & ND & ND & ND & NA & ND & ND \\
\hline $\begin{array}{l}\text { River } \\
\text { Downstream }\end{array}$ & 12 & 12.0 & 9.6 & 80 & 0.9 & 26.5 & 5.7 & 5.2 & 91 & ND & 16.9 \\
\hline JA IRB & 14 & 52.6 & 57.3 & 109 & 9.6 & 179 & 0.5 & 0.8 & 160 & ND & 21.8 \\
\hline JA $2 S$ & 16 & 291 & 89.4 & 31 & 61.0 & 414 & 6.9 & 7.8 & 113 & 0.9 & 23.9 \\
\hline JA 2D & 15 & 1710 & 1070 & 63 & 382 & 3420 & 23.7 & 24.2 & 102 & ND & 73.7 \\
\hline JA 3S & 17 & 110 & 50.9 & 46 & 46.2 & 218 & 1.7 & 1.7 & 100 & ND & 6.5 \\
\hline JA 3D & 17 & 4240 & 1340 & 32 & 2300 & 7020 & 77.5 & 76.7 & 99 & ND & 267 \\
\hline MW 18 & 15 & 8050 & 2390 & 30 & 3750 & 11920 & 706 & 215 & 30 & 425 & 1160 \\
\hline MW 18D & 15 & 7410 & 1730 & 23 & 5290 & 11200 & 1790 & 331 & 18 & 1240 & 2530 \\
\hline MW 44 & 14 & 1770 & 393 & 22 & 890 & 2310 & 68.5 & 37.8 & 55 & 12.3 & 1064 \\
\hline MW 56 & 12 & 3.6 & 4.0 & 111 & ND & 11.9 & 12 & 14.6 & 122 & ND & 46.3 \\
\hline $2 \mathrm{D}$ & 6 & 23.8 & 7.3 & 31 & 18.6 & 28.4 & 0.5 & 0.8 & 160 & ND & 1.6 \\
\hline $3 \mathrm{D}$ & 2 & 1700 & 650 & 38 & 1243 & 2170 & 23.5 & 25 & 106 & 6.3 & NA \\
\hline $4 \mathrm{D}$ & 11 & 114 & 55.3 & 49 & 50.8 & 228 & 23.6 & 5.4 & 23 & 14.5 & 30.8 \\
\hline 5D & 8 & 48.1 & 42.3 & 88 & 4.0 & 110 & 0.3 & 0.8 & 267 & ND & 2.1 \\
\hline
\end{tabular}

comparison, absolute MTBE and BTEX concentrations at JA 2S and JA 3S were significantly lower and fluctuated more frequently. Both wells had sustained higher concentrations during March and April as well as in late May. Concentration fluctuations in these wells may be related to antecedent moisture conditions reducing dilution or perhaps related to lower dissolved oxygen affecting biodegradation (Appendix III for DO).

Monitoring data at MW 18 and MW 18D has shown consistently high but overall declining concentrations of MTBE and BTEX since their installation. This pattern continued during this study with maximum MTBE concentrations occurring in January 2006 and declining through August 2006. These wells have also had historically high and declining BTEX concentrations which continued through this study with MW18D decreasing by $800 \mu \mathrm{g} / \mathrm{L}$. Conversely, MW 44 has historically 

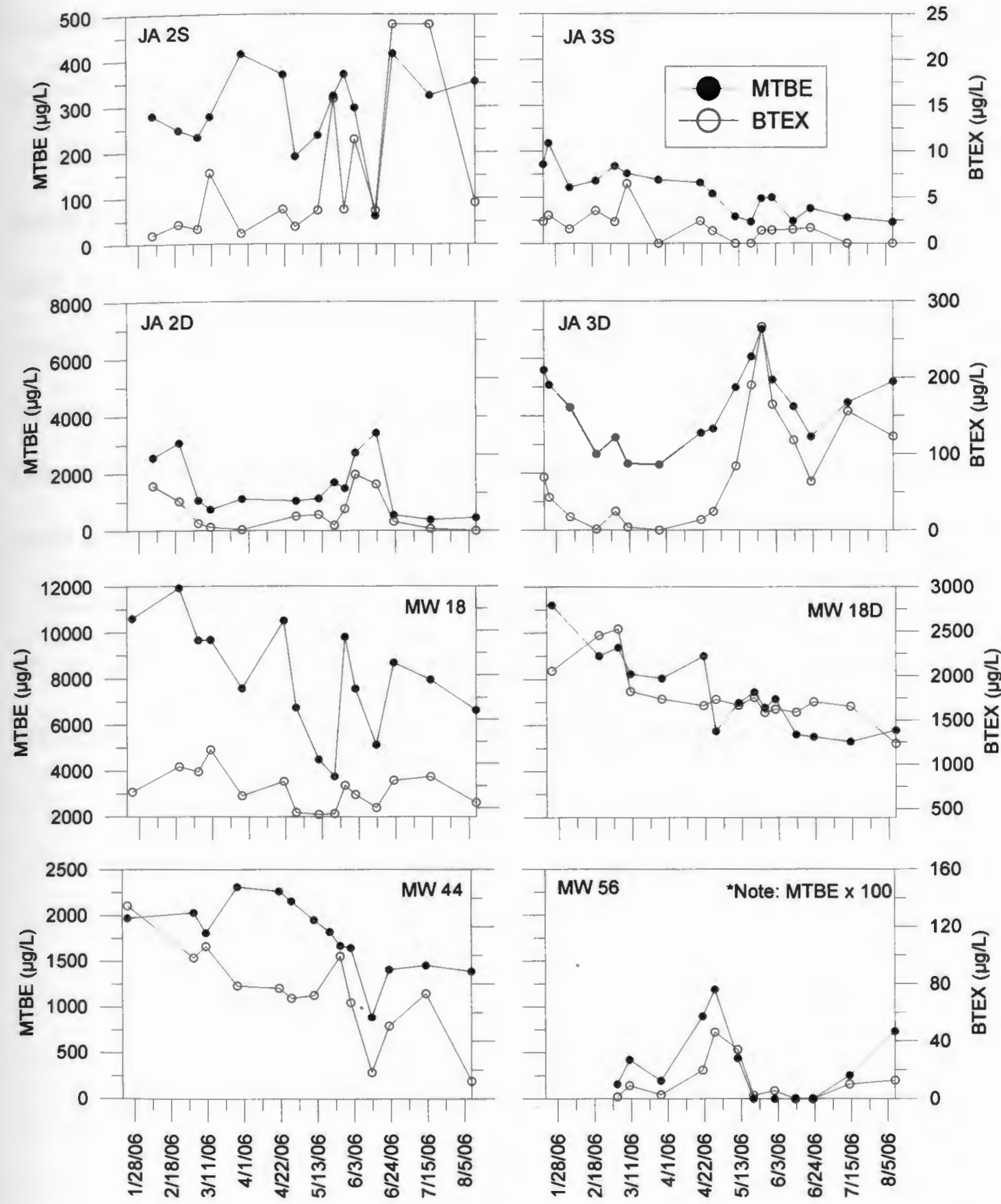

Figure 15. MTBE and BTEX concentration data for floodplain wells.

shown stable MTBE concentrations of approximately $2,000 \mu \mathrm{g} / \mathrm{L}$ since its installation in 2004. Except for a lower MTBE concentration during the overbank flooding in June, the concentration was close to this average. At MW 56, the average BTEX 
concentration was typically greater than the MTBE concentration; however, both were typically very low.

There were seven locations in the river and in the riverbed that were monitored during this study. There were no detections of MTBE and BTEX in upstream samples taken near the onsite dam. Downstream of the study area MTBE and BTEX contaminants were consistently detected (Figure 16). The highest downstream MTBE concentration was detected in early March and then decreased steadily through May before slightly increasing again. At JA 1R, MTBE was the only contaminant detected in the river over three periods in March, mid-May, and late June to mid-July.

Riverbed wells exhibited different contaminant concentrations and trends (Figure 17). Riverbed well 2D, located the farthest upstream, yielded a consistently low average MTBE concentration and BTEX was not detected except for low-level
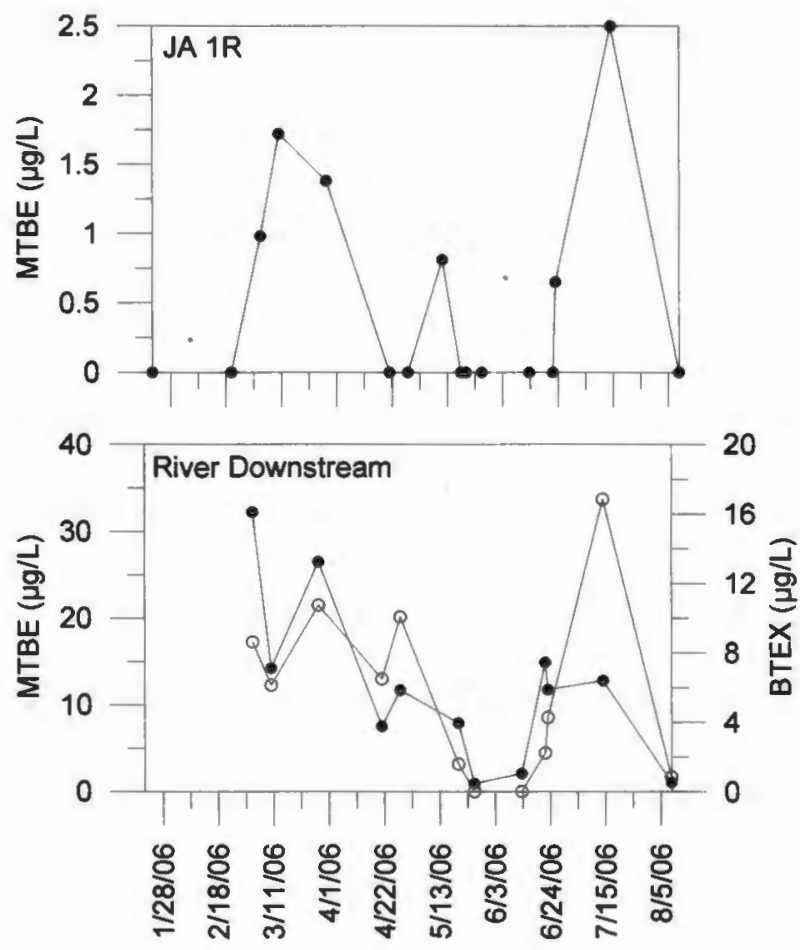

Figure 16. MTBE and BTEX concentrations in the river. 


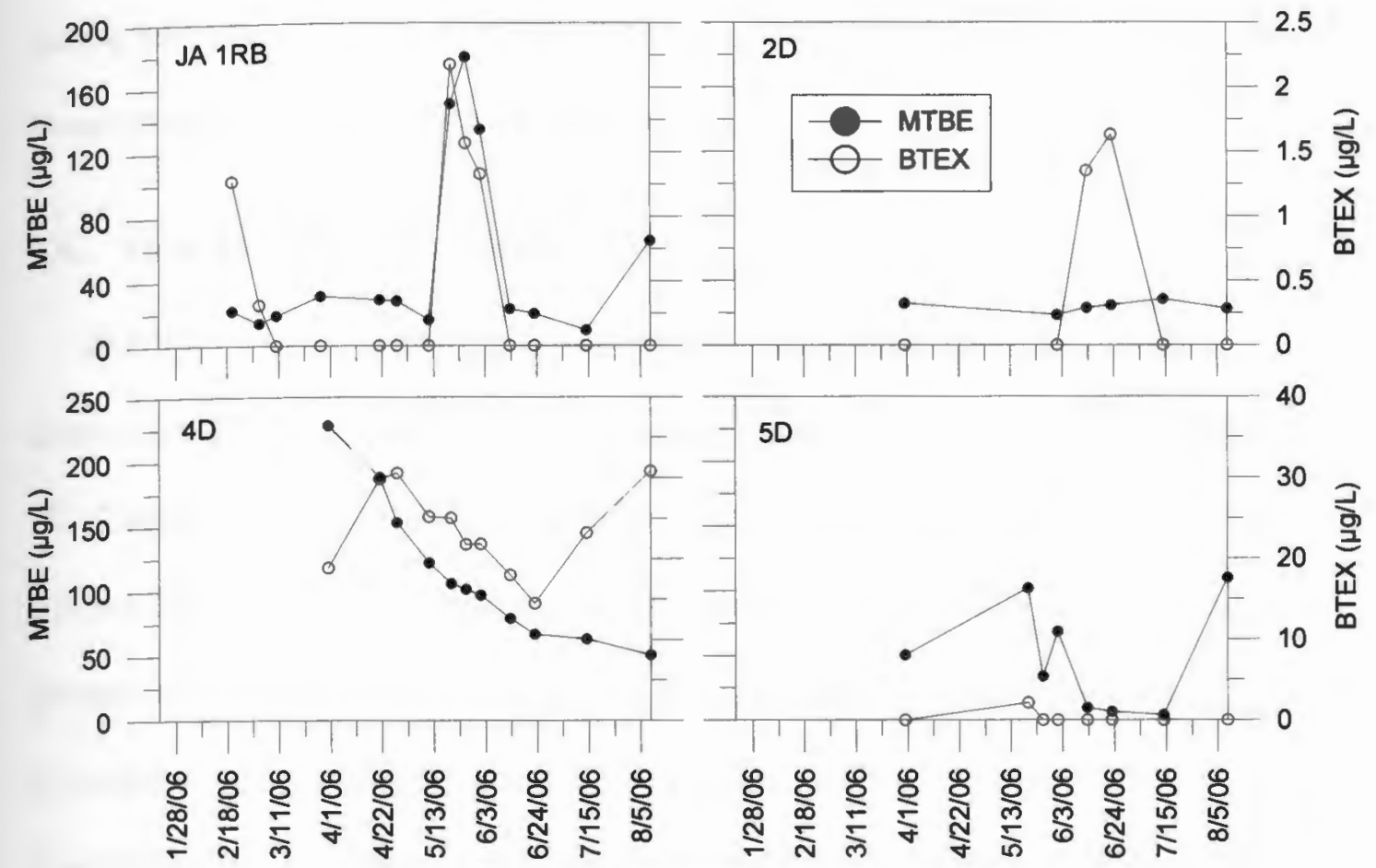

Figure 17. MTBE and BTEX concentrations in riverbed wells.

detection in early June. Riverbed well 3D located $18 \mathrm{~m}$ downstream from 2D showed over 2,000 $\mu \mathrm{g} / \mathrm{L}$ MTBE present on March 31 . Although only sampled twice during this study, long-term monitoring has occurred at this location since 2004 and historically has shown elevated MTBE concentrations of up to $5400 \mu \mathrm{g} / \mathrm{L}$. As consequence, relative to other points along the reach, this location appears to be a significant plume discharge location and needs to be further discussed. Riverbed well 4D, located $15 \mathrm{~m}$ downstream from 3D, had a maximum MTBE concentration of 228 $\mu \mathrm{g} / \mathrm{L}$ on March 31 and decreased steadily until the end of the study.

The final two riverbed wells, JA $1 \mathrm{RB}$ and $5 \mathrm{D}$, are located in the river at the study well transect. JA 1 RB MTBE concentration averaged $25 \mu \mathrm{g} / \mathrm{L}$ except for three sampling events in late May and June when MTBE increased to a maximum of 179 $\mu \mathrm{g} / \mathrm{L}$. Riverbed well 5D, located only $1.0 \mathrm{~m}$ from JA $1 \mathrm{RB}$ also had an MTBE increase 
during late May and June; however, the average and maximum concentration was lower than JA 1 RB throughout monitoring.

\subsection{Field Parameters and Ions}

In addition to the following brief summary, a complete list of results and discussion of field parameters, ions, and water temperatures is provided in Appendix III. Changes in EC and DO appear to be influenced by precipitation which dilutes shallow ground water and provides an oxygen source to the relatively oxygen depleted ground-water plume. In the deeper wells, this trend is replaced by increasing EC concurrent with the steepening hydraulic gradient and increasing MTBE concentrations. No trends in $\mathrm{pH}$ were identified throughout the monitoring period. EC correlated well to measured anion and cation concentrations, except where DO influenced the oxidation state of sulfate and nitrate. Table 7 summarizes the average ion concentration for several well groupings and shows some overall trends.

Table 7. Average cation and anion concentrations.

\begin{tabular}{|l|c|c|c|c|c|c|c|c|}
\cline { 2 - 10 } \multicolumn{1}{c|}{} & \multicolumn{4}{c|}{ CATIONS (mg/L) } & \multicolumn{4}{c|}{ ANIONS (mg/L) } \\
\cline { 2 - 10 } \multicolumn{1}{c|}{} & $\mathrm{Na}^{+}$ & $\mathrm{K}^{+}$ & $\mathrm{Mg}^{2+}$ & $\mathrm{Ca}^{2+}$ & $\mathrm{Cl}^{-}$ & $\mathrm{NO}_{3}{ }^{-}$ & $\mathrm{PO}_{4}{ }^{3-}$ & $\mathrm{SO}_{4}{ }^{2-}$ \\
\hline River & 20.1 & 1.4 & 0.8 & 3.5 & 15.7 & 0.6 & 0.1 & 6.3 \\
\hline Riverbed & 17.5 & 2.2 & 1.7 & 9.4 & 29 & 0.5 & 0 & 8.4 \\
\hline Shallow Wells & 48 & 5.9 & 6.2 & 42.9 & 93 & 0 & 0 & 2.5 \\
\hline MW 56 & 5.3 & 5.4 & 0.2 & 201 & 3.9 & 2.5 & 0 & 474 \\
\hline Deep Wells & 62 & 5.9 & 7.7 & 40 & 122 & 1.5 & 0 & 12.3 \\
\hline
\end{tabular}

In general, floodplain wells did not show any significant trends in water temperature other than deeper wells having lower temperature ranges. General temperature statistics are presented in Table 8 and graphs of well temperatures are located in Appendix III. Riverbed water temperature was useful in showing slight shifts in ground-water discharge and changes in hyporheic exchange. For example, 
the gate closure in July was accompanied by a decrease in riverbed water temperature in all wells. This indicates a cooler ground-water rather than surface-water source and suggests that more significant ground-water discharge is occurring than at other times.

Table 8. Temperature monitoring information and summary.

\begin{tabular}{|l|c|c|c|c|c|c|}
\cline { 2 - 7 } \multicolumn{1}{c|}{} & \multicolumn{2}{c|}{ Monitoring } & \multicolumn{4}{c|}{ Temperature $\left({ }^{\circ} \mathrm{C}\right)$} \\
\hline Well & Type & Begin Date & Minimum & Maximum & Average & Variability \\
\hline River & Transducer & $1 / 21 / 2006$ & 1.2 & 27.9 & 13.4 & 26.7 \\
JA 1RB & iButton & $4 / 21 / 2006$ & 9.6 & 19.3 & 14.6 & 9.7 \\
JA 2S & iButton & $4 / 21 / 2006$ & 6.4 & 14.3 & 9.8 & 7.9 \\
JA 2D & iButton & $4 / 21 / 2006$ & 8.1 & 10.5 & 8.9 & 2.4 \\
JA 3S & iButton & $4 / 21 / 2006$ & 7.3 & 14.6 & 10.8 & 7.3 \\
JA 3D & Transducer & $1 / 21 / 2006$ & 9.3 & 11.7 & 10.2 & 2.4 \\
MW 18 & iButton & $4 / 21 / 2006$ & 8.1 & 13.5 & 10.6 & 5.4 \\
MW 18D & Transducer & $1 / 21 / 2006$ & 9.1 & 12.1 & 10.4 & 3.0 \\
2D & iButton & $6 / 1 / 2006$ & 8.1 & 13.5 & 10.6 & 5.4 \\
4D & iButton & $4 / 21 / 2006$ & 9.8 & 18.3 & 13.5 & 8.5 \\
5D & iButton & $6 / 13 / 2006$ & 13.8 & 17.5 & 16.0 & 3.7 \\
\hline
\end{tabular}




\section{DISCUSSION}

The objective of this study was to assess the effect of fluctuating river stage on an MTBE plume discharging to Pascoag River by investigating variability in the hydraulic gradient. Results of this study indicate that the hydraulic gradient in the floodplain varied hourly to monthly creating nearly continuous fluctuation of the river between gaining, losing, and parallel-flow. These fluctuations also appear to affect the position of the MTBE plume within the floodplain and may impact contaminant discharge to the river.

The observed hydraulic behavior of the river and the hydraulic response of the floodplain to river stage and precipitation contradict the original conceptual model. First, short subsections of the river reach appeared to be losing while others have significant discharge of contaminated ground water and are gaining. And second, river stage increases and precipitation promoted a steepening of the hydraulic gradient towards the river. The factors responsible for these responses will be discussed as well as the implications to the contaminant plume and to the understanding of GW/SW interactions in general.

\subsection{Hyporheic Exchange}

Variations in hyporheic exchange created small-scale transient gaining, losing, and parallel flow systems along the reach by altering the hydraulic gradient immediately adjacent to the channel. Although a detailed analysis of the riverbed and riverbed exchange was not included with this study, limited hydraulic head, chemistry, and temperature data from the riverbed wells can be used to make inferences about small- 
scale exchange systems. The predominance of pool and riffle sequences, debris dams, and breaks in slope suggests short hyporheic flow paths of several meters (Figure 18). Upstream of 2D and 3D the river is shallow $(<0.5 \mathrm{~m})$ and gaining conditions exist as shown by low riverbed MTBE concentrations and seeps in the riverbed when river stage is low. A break in slope and a debris riffle at 3D result in downward flow at the head of the riffle and upward flow at the toe (Conant Jr. 2000; Conant Jr. 2004; Harvey and Bencala 1993; Kasahara and Wondzell 2003; Woessner 2000) which also marks the head of a deep pool $(>1.0 \mathrm{~m})$. Upward flow at 3D results in significant discharge of contaminated ground water as indicated by consistently high MTBE concentrations. Downstream at JA 1 RB and 5D, the channel shallows and a debris dam create losing and parallel-flow conditions as river water enters into the hyporheic zone (Conant Jr. 2000; Lautz and Siegel 2006). This is enhanced by the channel bend at $4 \mathrm{D}$ and river meandering downstream of $5 \mathrm{D}$ which causes water to enter the riverbank and flow parallel to the channel (Cardenas et al. 2004; Kasahara and Wondzell 2003; Woessner 2000) or pass through a lowland riparian area adjacent to the ground-water discharge location at MW 48. The structure and characteristics of the stone lining in the channel may also affect hyporheic exchange but the effects, if any, are unknown.

Areas of ground-water discharge and recharge and areas of no exchange to the river channel are controlled by hyporheic exchange can also be inferred from riverbed well temperature and chemistry data (Appendix III). Most riverbed temperatures are similar to surface-water temperatures making interpretation of water source difficult. Nevertheless, in all riverbed wells gradient steepening in the floodplain appears to 


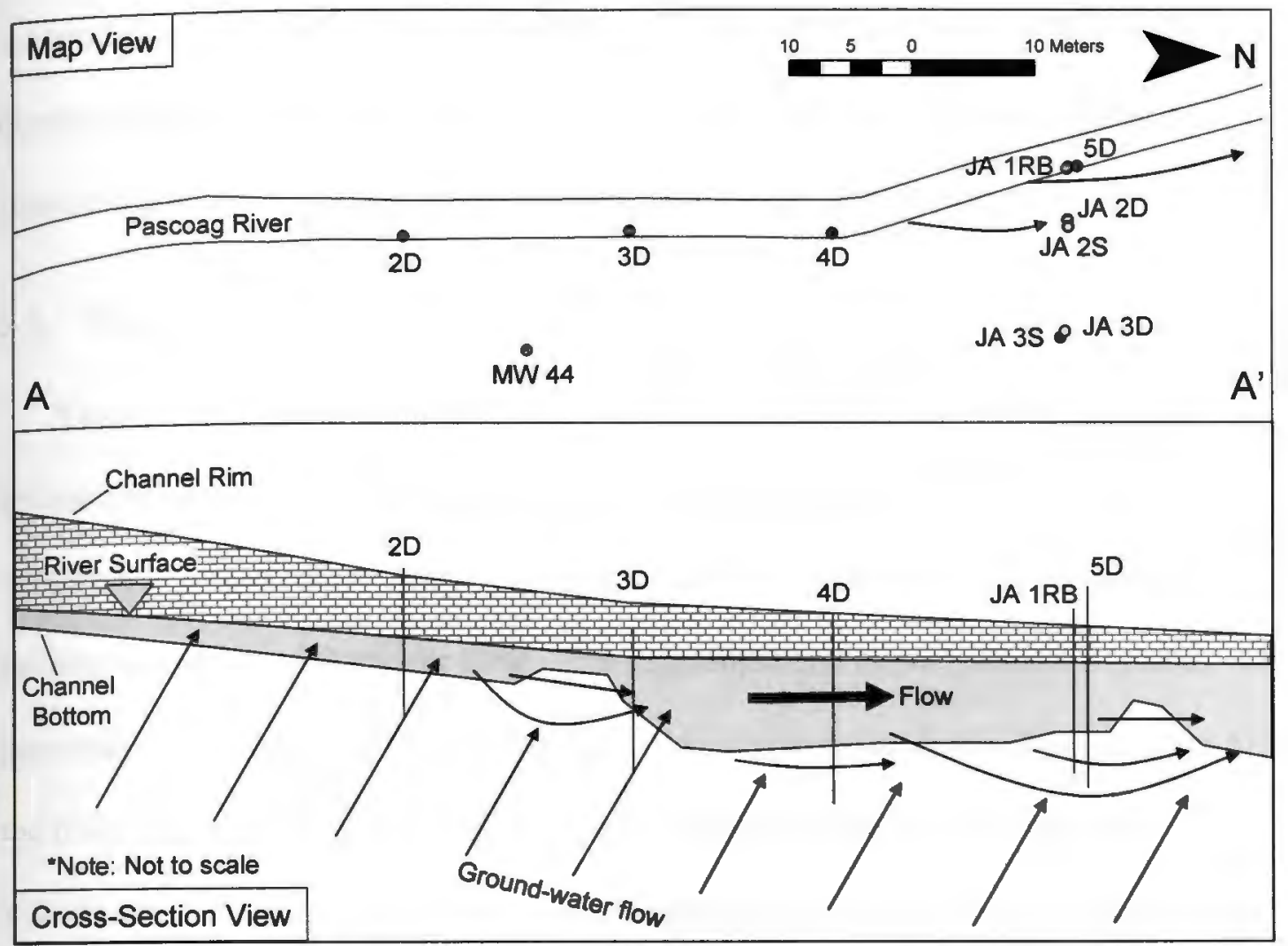

Figure 18. Channel morphology along river reach. Cross section from $A$ and $A^{\prime}$ as shown in Figure 6. The river is gaining upstream of $2 \mathrm{D}$ and $3 \mathrm{D}$ before a debris riffle creates losing conditions. Gaining conditions coincided with high MTBE concentrations in 3D. Parallel-flow and losing conditions persisted through the deep pool by 4D prior to channel shallowing and a debris dam creating losing conditions at JA 1RB and 5D.

correspond to decreases in riverbed and river water temperature, regardless of air temperature. This indicates ground-water flow toward the river along the entire reach and an influx of cooler ground water through the riverbed. Ground-water discharge through the riverbed is also generally corroborated by chemistry data including and increase in EC and MTBE, and a decrease in DO. For example, gaining conditions at JA 1RB in May coincided with higher MTBE concentrations and EC. In riverbed well 3D, high MTBE concentrations, water chemistry in the riverbed, and channel morphology support the inference that under stable conditions (i.e., no river stage fluctuations) significant contaminated ground-water discharge occurs at only this 
location along the reach. These observations indicate that along the entire reach, contaminated ground water is proximal to the channel but is able to discharge only when the gradient is sufficient to overcome small-scale hyporheic exchange.

\subsection{Floodplain Processes}

Variability of the floodplain hydraulic gradient is directly related to a dynamic interaction of several processes affecting the shallow water table: 1) water table recharge, 2) evapotranspiration, 3) ground-water flow, and 4) river stage fluctuations driving oscillation of the water table. The magnitude and impact of each of these processes is dependent on the reservoir gate which also controls the characteristics of the river stage hydrograph and the hydraulic response of the aquifer (Table 9).

Additionally, successive hydraulic gradient steepening periods have a compounding effect that ultimately have a more significant impact on water quality than individual events.

Table 9. Factors and relative importance in controlling hydraulic gradient response in the floodplain.

\begin{tabular}{|l|c|c|c|c|c|}
\hline \multirow{2}{*}{} & \multicolumn{2}{|c|}{ Spring } & \multicolumn{2}{c|}{$\begin{array}{c}\text { Summer } \\
\text { River Stage High }\end{array}$} & $\begin{array}{c}\text { Summer } \\
\text { River Stage Low }\end{array}$ \\
\cline { 2 - 6 } & $\begin{array}{c}\text { DRY (A) } \\
\text { - April - }\end{array}$ & $\begin{array}{c}\text { WET (B) } \\
\text { - Mid May - }\end{array}$ & $\begin{array}{c}\text { DRY (C) } \\
\text { - Late May - }\end{array}$ & $\begin{array}{c}\text { WET (D) } \\
\text { - June - }\end{array}$ & $\begin{array}{c}\text { DRY (F) } \\
\text { - July - }\end{array}$ \\
\hline Recharge & Significant & Significant & Limited & Significant & Significant \\
\hline ET & Limited & Limited & Significant & Limited & Significant \\
\hline GW Flow & Moderate & Limited & Significant & Moderate & Significant \\
\hline
\end{tabular}

Other possible factors controlling water table responses at individual wells are depth, local surface material, location of the well screen (Saines 1981), and proximity to surface-water runoff.

The following is a discussion analyzing floodplain processes during several periods of this study referring back to the hydraulic gradient variability between JA 2 S 
and the River (Figure 11) which had the largest hydraulic gradient variability and steepening in the floodplain. The hydraulic gradient curve can be separated into six periods ( $A$ though $F$ ) based on river stage elevation. This includes the low-stage periods in early spring $(A \& B)$ and late summer $(F)$, the high-stage period in late spring to early summer $(C \& D)$, and the transitional periods in mid-February, midMay, and early July corresponding to sudden river stage changes due to gate adjustments $(E)$.

\subsubsection{Low River Stage}

\section{Spring Dry Period (A)}

Precipitation in this period was relatively infrequent, river stage was low, and there was a low hydraulic gradient away from the river channel at JA 2S. Episodic shortduration precipitation events created a significant transient effect on the otherwise stable hydraulic gradient. During a two-part precipitation event on April 23 and 24, 2006, river stage and the floodplain water table rose nearly concurrent with precipitation (Figure 19). In the two hours between individual precipitation events, river stage receded and then increased with the subsequent rainfall. Flashiness was magnified with the gate closed, preventing sustained discharge and decreasing stormflow lag time. All wells in the study area responded similarly to river stage during the first event, but the water table response to the second event was exacerbated by saturated soil conditions and the water table rose more than river stage. As a result, the river which was initially slightly losing, reversed and became strongly gaining as the head in JA $2 \mathrm{~S}$ was well above river stage. The greatest floodplain well response came from the wells closest to the river and diminished with increasing distance from 


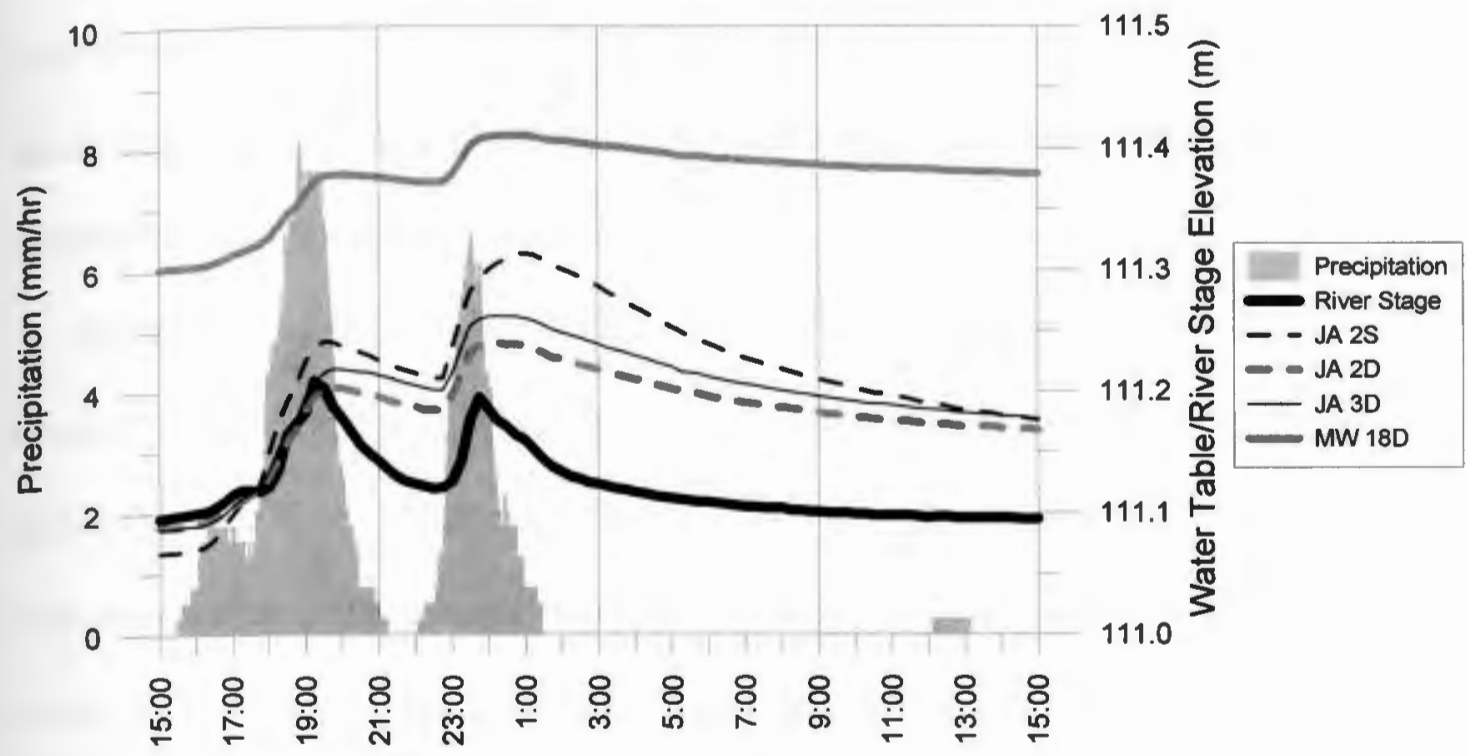

24-hours starting 4/23/06

Figure 19. 24-hour river stage and water table response to precipitation event on 4/23 - 4/24. Shows the initial similar response at all locations followed by river stage decline then subsequent increase. This results in steep hydraulic gradient from JA $2 S$ to river and throughout the floodplain.

the channel. Ritter et al. (2002) described this response and Sklash and Farvolden (1979) made a similar observation which they attributed ground-water ridging, a process where rapid water table recharge forms a ridge or mound adjacent to the river channel. The exact shape of the water table irregularity is related to site specific properties of the landscape and the aquifer material. According to this theory, the ridge forms due to almost instantaneous saturation of the capillary fringe and rapid rise in the water table. In Pascoag, the capillary fringe may extend to between 50 and 100 $\mathrm{cm}$ above the water table, depending on specific soil properties (Fetter 1994). Ridge formation temporarily steepens the hydraulic gradient and results in increased discharge and contribution to stormflow. According to Figure 19, gradient steepening both towards the river and the topographical high near the source zone may occur; however, a flat hydraulic gradient between JA 3D and JA 2D does not indicate 
occurrence of flow towards the slope. Following precipitation events, the groundwater ridge dissipates due to lateral drainage and the slightly losing gradient is reestablished until the next precipitation event.

This hydraulic gradient response is also related to antecedent soil moisture conditions (field capacity), which is similar to but independent of capillary fringe processes. The field capacity of a fine sandy loam is approximately 0.25 and decreases during dry periods (Fetter 2001). During large or successive precipitation events, infiltration elevates soil moisture and soil may reach saturation resulting in a rapid rise of the water table.

Spring Wet Period (B)

During the middle of May there were several days of sustained precipitation that kept soil moisture high, the water table high, and ET low. The gate was still closed resulting in low river stage extending through these precipitation events. Direct watertable recharge at the surface led to a large head difference and a sustained steepened hydraulic gradient of approximately $0.06 \mathrm{~m} / \mathrm{m}$ towards the river. As the reservoir level reached the overflow spillway and river stage slowly increased, the head difference was reduced and the gradient flattened.

Summer Dry Period (F)

During the summer dry period, the floodplain water table was equilibrating to the lower river stage. The ET rate was high and resulted in low amplitude diurnal fluctuations in the water table and hydraulic gradient. This indicates that the water table and capillary fringe are still within influence of surface processes. Soil saturation may remain relatively high due to extension of the capillary fringe which 
facilitates ground-water recharge during precipitation (Fetter 2001). This allows the water table in July and August to have a similar response to precipitation events as the earlier dry period in the spring.

\subsubsection{High River Stage}

\section{Spring Dry Period $(C)$}

In late May 2006, a short dry spell and high ET promoted a steady water-table decline enhanced by a shallow water-table depth and decreasing reservoir spillway contributions. River stage discharge was sustained with the reservoir gate open and river stage remained high. As the water table flattened, the losing gradient between the river and JA $2 \mathrm{~S}$ was reestablished.

Spring Wet Period (D)

This period was hydraulically unstable as two major precipitation events occurred raising the river to flood stage and causing floodplain inundation. The hydraulic gradient responded by repeatedly alternating between gaining and losing, presumably in response to the direct water table recharge at the surface (Fetter 2001). Flattening of the floodplain water table and the vertical and horizontal gradients may have been initiated by overbank flooding on June 8, 2006 (Girard et al. 2003). Following precipitation events, the water table was close to the surface which amplified the influence of ET and caused the water table to decline rapidly.

\subsubsection{Effect of Gate $(E)$}

The transition between low river stage and sustained high river stage occurred rapidly and was generally only related to opening or closing of the reservoir gate. In 
this system, natural seasonal variability in stream flow is muted by the dominance of the reservoir effect. The transitional period immediately after a gate adjustment is perhaps the most dynamic period as the floodplain aquifer and water table must equilibrate to a new hydraulic relationship with the river. This is best exemplified after the gate closure in July, where immediately following gate closure a relatively steep gradient $(0.03 \mathrm{~m} / \mathrm{m})$ was established between the aquifer and the river and slowly diminished as the water table declined. If not for the precipitation events, the system presumably would have stabilized and the river would have reverted back to a slightly losing gradient. This process results in a flushing effect in the aquifer as it releases a large volume of ground water from storage.

Gate opening and rapid river stage increase in the absence of precipitation on May 18 and June 1, 2006, may result in limited traditional bank storage. In this case, because river stage rise is not accompanied by precipitation, ground-water ridging does not occur and the hydraulic gradient steepens away from the channel, enhancing losing river conditions.

\subsection{Comparison to other GW/SW interaction studies}

Literature review indicates the results of this study are similar to some but generally different from others. Although the process has been described in textbooks (Ritter et al. 2002), few studies identified a similar process of ground-water recharge leading to strengthening of gaining conditions (Wroblicky et al. 1998). Many studies indicate a response similar to the classic model of bank storage, others report highly transient and variable ground-water flow, hyporheic exchange, and GW/SW interface 
Table 10. Literature comparison of watershed area to stormflow response. Some studies did not report basin area or only indicated stream order. These rivers had to be checked for watershed areas. See Appendix III for specific references used.

\begin{tabular}{|l|c|c|l|}
\hline \multicolumn{1}{|c|}{$\begin{array}{c}\text { Watershed Size } \\
\text { Studied }\end{array}$} & $\begin{array}{c}\text { Number of } \\
\text { Studies }\end{array}$ & $\begin{array}{c}\text { Average Area } \\
\left(\mathrm{km}^{2}\right)\end{array}$ & \multicolumn{1}{|c|}{$\begin{array}{c}\text { Typical } \\
\text { Stormflow Response Type }\end{array}$} \\
\hline Small $\left(<100 \mathrm{~km}^{2}\right)$ & 10 & 47.5 & Transient Hyporheic \\
\hline Medium $\left(100-1,000 \mathrm{~km}^{2}\right)$ & 2 & 324 & Mixed \\
\hline Large $\left(>1,000 \mathrm{~km}^{2}\right)$ & 12 & 86,500 & Bank Storage \\
\hline $\begin{array}{l}\text { Mixed }(>1,000 \text { to }<100 \\
\left.\mathrm{km}^{2}\right)\end{array}$ & 3 & $1^{\text {st }}-5^{\text {th }}$ Order & Mixed \\
\hline
\end{tabular}

position. Taking a closer look reveals that high-order river systems typically respond with bank storage while low-order river systems typically respond with alteration of small-scale transient hyporheic processes (Table 10). This is similar to the process described by Kasahara and Wondzell (2003) regarding the importance of channel morphology controls on second- versus fifth-order rivers. This response may be related to stormflow lag time which is dependent on several watershed factors, including basin size, discharge per unit area, and other basin characteristics (Ritter et al. 2002). Large river systems tend to have longer lag times with disconnected precipitation and stormflow. Pascoag River has only a slight lag between precipitation and stormflow which is consistent with a low-order river with a small watershed that responds quickly to recharge. River stage is also sensitive to changes in predominate landuse, with vegetated uplands providing sustained discharge to the river with the gate open and increased proportion of impervious surfaces generating flashy storm runoff with the gate closed.

Basin lag is important to consider in ground water/surface water interaction studies due to bank storage and gradient reversal processes. Typically in these studies, river stage increases leading to a temporary gradient reversal and bank storage are expected and even assumed. This model seems valid in high order systems but in low order 
systems, such as Pascoag River, the timing of the river stage increase relative to watertable response precludes the reversal. Instead, precipitation quickly recharges the shallow floodplain water table creating a ground-water ridge or mound. River stage also increases, but due to the over-response from the water table, bank storage can not occur and instead steepening of the hydraulic toward the river is promoted. Thus, river order appears more important than typically realized when considering the expected response of a coupled ground-water/surface-water system to recharge and to river stage and water table fluctuations.

\subsection{Contaminant Fate and Transport}

This study marked the first extensive ground water/surface water interaction investigation at the Pascoag site. The data suggests that steepening of the hydraulic gradient shifts a portion of contaminated ground-water discharge to an upgradient location. Prolonged and successive gradient steepening towards the river likely affects the plume discharge more significantly than individual or short-term steepening. The results indicate that a more complex and transient-ground-water interaction with surface water exists than originally perceived. This altered conceptual model of the plume behavior has important implications for this site and other sites where similar complex interactions may occur.

\subsubsection{Plume Dynamics}

Combining the floodplain hydraulic gradient with contaminant distributions allows for development of a conceptual model of transient contaminant fate and transport. Steepening of the gradient between MW 56 and MW 18 results in increased ground- 
water discharge in the floodplain but the overall flow regime does not change significantly. There appears to be no significant impact on MTBE concentrations due to the fluctuating gradient at MW 18 and decreasing concentrations may indicate a diminishing source zone. Relatively high concentrations at MW 44 indicate that the plume discharges to the floodplain at this location but is only consistently able to discharge to the river near 3D. When the gradient is low, the center of the plume is
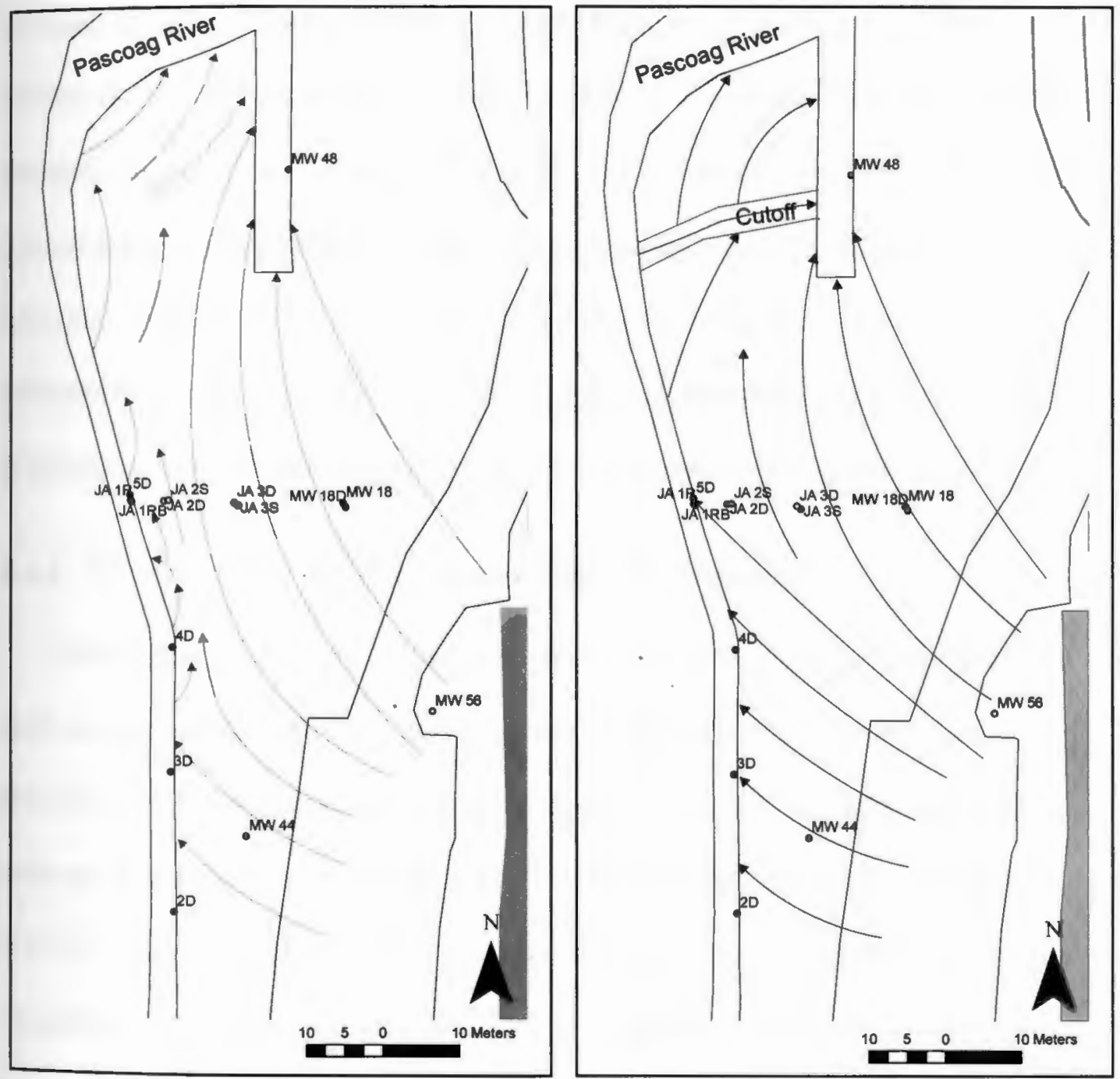

Figure 20. Conceptual model of ground-water flow in floodplain during a low-gradient period (left) and in a steep gradient period (right). When the gradient is low, upstream discharge occurs only near 3D due to plume deflection toward MW 48 by small-scale hyporheic exchange. Gradient steepening allows ground-water to discharge along the reach as the hyporheic zone shrinks or disappears. 
deflected by hyporheic processes parallel to or away from the river channel towards the downgradient focused ground-water discharge location near MW 48 (Figure 20). When the gradient steepens between JA $2 \mathrm{~S}$ and the river, the hyporheic processes are overcome and significant discharge occurs along the entire reach (Figure 20). Further ground-water and surface-water flow alteration occurs due to a channel cutoff that develops over the lowland riparian area and into the discharge are near MW 48. The increase in MTBE concentration in JA 2D without a steepening gradient between JA $3 \mathrm{~S}$ and JA 2S indicates that the plume must migrate from upgradient near MW 44. Ground water transport along this flow path may be enhanced by a former channel that has subsequently been filled. Historical photographs show this channel was 4 to $5 \mathrm{~m}$ wide and was probably 1 to $2 \mathrm{~m}$ deep (Appendix I). This buried channel coupled withother buried structures has created complicated subsurface geology and has precluded a detailed investigation by RIDEM in the area around MW 18, 44, and 56.

\subsubsection{Ground-water Monitoring and Natural Attenuation}

Ground water at the Pascoag site and most other sites is monitored quarterly to semi-annually as specified by individual site operation and management plans (Hazardous Waste Clean-Up Information 2007). This plan is usually adequate for sites not in proximity to surface water. The results of this study indicate that a GW/SW interaction survey with high resolution spatial and temporal water-quality sampling and hydraulic gradient data may be required to accurately delineate and monitor a plume discharging to surface water. While this may be a costly upfront proposition, it may help avoid higher long-term operation and management costs. 
Although Pascoag has undergone extensive pump-and-treat remediation, biological degradation and discharge to the river has aided in natural attenuation of the plume. Hinzman et al. (2000) showed that compared to active remediation, natural discharge of contaminants to surface water can remove an equal mass of contaminants from the system. In Pascoag, the contaminant mass discharged to the river varied considerably and was not solely related to dilution but probably a combination of dilution and variable ground-water discharge. Downstream from the study area, MTBE mass discharged by the river varied between $3 \mathrm{~g} /$ day and $1100 \mathrm{~g} /$ day and BTEX $0 \mathrm{~g} /$ day and $220 \mathrm{~g} /$ day. Periods of high ground water and contaminant mass discharge coincided with aquifer flushing during the steep gradient periods induced by precipitation and gate closure. This can potentially affect stream health and benthic habitats with pulses of high-level contaminants (Barlow et al. 2000; Schilling et al. 2006) rather than low-level continuous exposure and could easily be missed by quarterly monitoring. It may also complicate estimation of long-term contaminant discharge and total maximum daily loads.

Water table fluctuations and the continuous shifting of the ground-water plume may affect biodegradation and smear contaminants above the water table and into different areas of the floodplain. Degradation may also be influenced by the alternating of gaining and losing river conditions and the resulting effect on dissolved oxygen delivery to the riverbed and riparian zone. This impact was not assessed in this study, nor was a more detailed analysis of contaminant fate. 


\subsection{Limitations and Sources of Error}

There are several limitations of this study and to the associated data. For instance, monitoring of the water levels and subsequent water-table elevations contain some inherent error (Table 11). The scale of these errors may render some perceived hydraulic gradient fluctuations insignificant. Nonetheless, the consistency of the

Table 11. Transducer measurement QA/QC. Error was usually associated with disturbing transducer during sampling or insufficient water table reequilibration after pumping prior to transducer starting.

\begin{tabular}{|l|c|c|}
\hline Well & $\begin{array}{c}\text { Monitoring } \\
\text { Periods }\end{array}$ & $\begin{array}{c}\text { Mean Error } \\
\text { Per Period } \\
(\mathrm{m})\end{array}$ \\
\hline JA 1R & 10 & 0.005 \\
JA 2S & 7 & 0.008 \\
JA 2D & 11 & 0.004 \\
JA 3D & 11 & 0.002 \\
MW 18D & 10 & 0.017 \\
\hline
\end{tabular}

results and the independent corroboration between parameters indicates that trends are accurate.

While some of the characteristics of the Pascoag River and this site make it relatively unique, there is still valuable information to be processed. The data obtained during this research is applicable to rivers with small watersheds, rivers that are flashy, and most importantly to all locations where plumes discharge to surface water. Because of the intrinsic nature of this topic, the scale of responses and transience may vary from site to site; however, the processes influencing the system should remain similar. Furthermore, it is important to understand what site specific information and characterization studies should be completed before developing site remediation and monitoring plans. 
This study is also limited by the scale of this thesis, to the original conceptual model, and to the thesis question at hand. Because of this, there was certain field data not collected or included in this work. For example, this thesis is not able to identify the exact location of discharge when the plume discharge location apparently shifts upstream. It should also be noted that ground-water and contaminants may still be entering the floodplain downgradient of the well transect related to the northward ground-water contaminant flowpath described above. More monitoring well locations would allow for a complete transient plume delineation. Similarly, more riverbed wells would allow for identification of additional contaminant discharge locations and would complete the model of hyporheic exchange along this river reach. Soil properties including soil moisture, grain size, and soil thickness would have aided in explaining vadose zone and capillary fringe processes. And finally, no analysis of changes to contaminant degradation was included as part of this study. 


\section{SUMMARY AND CONCLUSIONS}

This study demonstrates the complex and transient relationships that occur where ground water and surface water interact. The research objective of this study was to assess the effects of fluctuating river stage on an MTBE contaminant plume discharging to the Pascoag River. Results show that the hydraulic gradient fluctuates hourly to monthly, due to river stage and floodplain water table response to precipitation and reservoir gate adjustments. The river along this reach is predominantly gaining; however, hyporheic exchange processes vary spatially and temporally, forming small-scale gaining, losing, and parallel flow systems.

Precipitation events rapidly recharge the shallow floodplain water table, causing ground-water ridging and steepening of the hydraulic gradient towards the river. Even though this response also occurs when river stage is high, ultimately, river stage fluctuations have the largest influence controlling the response of the aquifer. The magnitude of these fluctuations is directly related to the size of the watershed which drives river flashiness, prevents sustained stormflow, and enhances the gradient toward the river.

The gasoline contaminant plume is significantly affected by shifting and steepening of the hydraulic gradient. Under stable hydraulic conditions, the plume enters the floodplain adjacent to MW 44, but only a small portion is able to discharge to the river. Instead, hyporheic flow deflects the plume downgradient parallel to the river where it can discharge. When the hydraulic gradient steepens towards the river following a precipitation event, the hyporheic exchange systems shrink or disappear and the plume enters the river channel farther upgradient. Gradient steepening 
following precipitation and gate closures results in a flushing effect of the floodplain generating a high influx of contaminated ground water to the river. These episodic releases may impact the stream and benthic habitats more dramatically than long-term low exposure.

Interpretation of these results indicates that the current understanding of GW/SW interactions is able to explain many of the significant processes occurring in floodplains but work still remains. Several questions, comments, and conclusions arise from this work:

- Floodplain processes, including water-table recharge, ET, and ground-water flow, play key roles in controlling the water table position relative to river stage. Where the water table is high, soil properties and antecedent moisture conditions may allow the capillary fringe to extend close the surface, enhancing water table recharge and ground-water mounding during precipitation events.

- Reporting river order is often considered an ancillary requirement of groundwater/surface-water interaction studies. The results of this study indicate that river order may contribute significantly to controlling hydrograph characteristics including lag time and stormflow duration. When river stage rise is concurrent with precipitation, infiltration and subsequent water table rise may prevent bank storage. Furthermore, if the watershed is small, stormflow may recede soon after precipitation ends and the gradient towards the river may steepen. Floodplain characteristics including slope, vegetation, water table depth, soil properties, and antecedent moisture are all factors that control this response. 
- The presence of a dam can affect floodplain hydrology by producing episodic shifts in the hydraulic gradient, flushing of the aquifer, and occasional induced bank storage. Watershed reduction with dam closures can drastically affect river hydrographs and affect floodplain processes.

- Typical ground-water monitoring frequency may be inadequate to delineate transient plume characteristics where discharge to surface water occurs. An initial assessment should be made to determine spatial and temporal plume interaction and stability. Focusing on "snapshot" contaminant and hydraulic gradient distributions may create an incomplete and misleading conceptual model. Hydraulic gradient alteration and plume movement may be more likely to occur where river stage and/or water table fluctuations are more significant.

- The already complex conceptual model of GW/SW interactions becomes even more complicated when contaminant discharge occurs to surface water. Shifting water table configurations and hydraulic gradient magnitudes affect ground-water flow and can change discharge locations. A ground-water plume discharging to surface water may have several discharge locations related to transient water-table configurations. Even along a gaining river, channel and riverbed geomorphology may create small-scale hyporheic variability resulting in losing, gaining, and parallel-flow conditions adjacent to the channel which can deflect the plume and impact discharge locations. An effort should be made by governing agencies to facilitate large-scale research at contaminated sites where discharge to surface water occurs in order to assess these GW/SW interactions. 


\section{REFFERENCES}

Allen, J.L. 2005. Quaternary Geologic Map of the Chepachet Quadrangle, Rhode Island. Unpublished report.

Allen, J.L., and T.B. Boving. 2006. Summary of 2005 aquifer test and groundwater flow dynamics, Pascoag, Rhode Island. Technical Report submitted to the RI Department of Environmental Management.

Barlow, L.K. 2003. Estimated water use and availability in the Lower Blackstone River Basin, northern Rhode Island and south-central Massachusetts, 1995-99. USGS Water-Resources Investigations Report 03-4190.

Barlow, P.M., L.A. DeSimone, and A.F. Moench. 2000. Aquifer response to streamstage and recharge variations II. Convolution method and applications. Journal of Hydrology 230: 211-229.

Boano, F., R. Revelli, and L. Ridolfi. 2007. Bedform-induced hyporheic exchange with unsteady flows. Advances in Water Resources 30, no. 1: 148-156.

Burrillville Preservation and Historical Society. 2005. http://www.onfrozenpond.com /people-bhps.htm. Accessed 11/21/05.

Burt, T.P., P.D. Bates, M.D. Stewart, A.J. Claxton, M.G. Anderson, and D.A. Price. 2002. Water table fluctuations within the floodplain of the River Severn, England. Journal of Hydrology 262: 1-20.

Burt, T.P., G. Pinay, F.E. Matheson, N.E. Haycock, A. Butturini, J.C. Clement, S. Danielescu, D.J. Dowrick, M.M. Hefting, A. Hillbricht-Ilkoska, and V. Maitre. 2002. Water table fluctuations in the riparian zone: comparative results from a pan-European experiment. Journal of Hydrology 265: 129-148.

Cardenas, M.B., J.L. Wilson, and V.A. Zlotnik. 2004. Impact of heterogeneity, bed forms, and stream curvature on subchannel hyporheic exchange. Water Resources Research 40: no. 8: 1141-1155.

Castro, N.M., and G.M. Homberger. 1991. Surface-subsurface water interactions in an alleviated mountain stream channel. Water Resources Research 27, no. 7: 1613-1621.

Chen, $\mathrm{Xi}$, and $\mathrm{Xu}$. Chen. 2003. Stream water infiltration, bank storage, and storage zone changes due to stream-stage fluctuations. Journal of Hydrology 280: 246264. 
Conant Jr., B. 2000. A federal statutory/regulatory/policy perspective on remedial decision-making with respect to ground-water/surface-water interaction. In Proceedings of the ground-water/surface-water interactions workshop, 23-30: EPA/542/R-00/007.

Conant Jr., B., 2004, Delineating and quantifying ground-water discharge zones using streambed temperatures. Ground Water 42, no. 2: 243-257.

Conant Jr., B., J.A. Cherry, and R.W. Gillham. 2004. A PCE groundwater plume discharging to a river: influence of the streambed and near-river zone on contaminant distributions. Journal of Contaminant Hydrology 73: 249-279.

Einarson, M.D., and D.M. Mackay. 2001. Water contamination. Environmental Science \& Technology 35, no. 3: 67-73.

Fetter, C.W.1994. Applied Hydrogeology. $3^{\text {rd }}$ ed. New Jersey: Prentice Hall.

Fetter, C.W. 2001. Applied Hydrogeology. $4^{\text {th }}$ ed. New Jersey: Prentice Hall.

Fryar, A.E., E.J. Wallin, and D.L. Brown. 2000. Spatial and temporal variability in seepage between a contaminated aquifer and tributaries to the Ohio River. Ground Water Monitoring \& Remediation 20, no. 3: 129-146.

Gill, M.A. 1985. Bank storage characteristics of a finite aquifer due to sudden rise and fall of river level. Journal of Hydrology 76: 133-142.

Girard, P., C.J. da Silva, and M. Abdo. 2003. River-groundwater interactions in the Brazilian Pantanal. The case of the Cuiabá River. Journal of Hydrology 283: 57-66.

Hantush, M.M.. 2005. Modeling stream-aquifer interactions with linear response functions. Journal of Hydrology 311: 59-79.

Harvey, J.W., and K.E. Bencala. 1993. The effect of streambed topography on surface-subsurface water exchange in mountain catchments. Water Resources Research 29, no. 1: 89-98.

Hayashi, M., and D.O. Rosenberry. 2002. Effects of ground water exchange on the hydrology and ecology of surface water. Ground Water 40, no. 3: 309-316.

Hazardous Waste Clean-Up Information. 2007. http://www.clu-in.org/conf/tio/ sfoandm1 _092004/prez/ompart2pdf.pdf. Accessed 3/7/07.

Hem, J.D. 1985. Study and interpretation of chemical characteristics of natural water. USGS Water-Supply Paper 2254. 
Hermes, O.D., L.P. Gromet, and D.P. Murray. 1994. Bedrock Geologic Map of Rhode Island. Rhode Island Map Series No. 1.

Hinzman, L.D., M. Wegner, and M.R. Lilly. 2000. Hydrologic investigations of groundwater and surface-water interactions in subarctic Alaska. Nordic Hydrology 31, no. 4/5: 339-356.

Hudson, N.W. 1993. Field measurements of soil erosion and runoff. Ampthill Bedford UK: Silsoe Associates.

Hunt, R.J., M. Strand, and J.F. Walker. 2006. Measuring groundwater-surface water interaction and its effect on wetland stream benthic productivity, Trout Lake watershed, northern Wisconsin, USA. Journal of Hydrology 320: 370-384.

Job, C.A., and J.J. Simons. 1996. Ground and surface water interaction, watershed management, and monitoring. Ground Water 16, no. 3: 68-69.

Kasahara, T., and S.M. Wondzell. 2003. Geomorphic controls on hyporheic exchange flow in mountain streams. Water Resources Research 39, no. 1: 1005-1116.

Kim, H., and H.F. Hemond. 1998. Natural discharge of volatile organic compounds from contaminated aquifer to surface water. Journal of Environmental Engineering 124, no. 8: 744-751.

Lambs, L. 2004. Interactions between groundwater and surface water at river banks and the confluence of rivers. Journal of Hydrology 288: 312-326.

Laserbeams.com. 2006. www.laserbeams.com. Accessed 09/06.

Lautz, L.K., and D.I. Siegel. 2006. Modeling surface and ground water mixing in the hyporheic zone using MODFLOW and MT3D. Advances in Water Resources 29, no. 11: 1618-1633.

Missouri Census Data Center. 2006. http://mcdc2.missouri.edu/cgi-bin/broker? PROGRAM=websas.dp3_2k.sas\&_SERVICE=sasapp\&zi $=02859$. Accessed $12 / 06$.

Moran, M.J., J.S. Zogorski, and P.J. Squillace. 2005. MTBE and gasoline hydrocarbons in ground water of the United States. Ground Water 43, no. 4: 615-627.

National Climatic Data Center (NCDC).2006. wwwl.ncdc.noaa.gov. Accessed 10/06.

Nichols, D.S., and E.S. Verry. 2001. Stream flow and ground water recharge from small forested watersheds in north central Minnesota. Journal of Hydrology 245: 89-103. 
Oklahoma Water Resources Board. 2004. Water quality programs division: standard operating procedure for the use of floats to determine stream discharge. Oklahoma City, Oklahoma.

Plouffe, L. 2006. Personal communication.

Puls, R.W., and M.J. Barcelona. 1996. Ground water issue: low-flow (minimal drawdown) ground-water sampling procedures. $E P A / 540 / S-95 / 504$.

Quinn, A.W. 1967. Bedrock Geology of the Chepachet Quadrangle, Providence County, Rhode Island. Geological Survey Bulletin 1241-G, Plate 1.

Rector, D.D. 1981. Soil survey of Rhode Island: United States Department of Agriculture Soil Conservation Service in Cooperation with Rhode Island Agricultural Experiment Station.

Rhode Island Department of Environmental Management (RIDEM) unpublished data

Rhode Island Geographic Information Systems. 2006. http://www.edc.uri.edu/rigis/ aerialse/ aerial 1939/39Northindex.htm. Accessed 04/06.

Ritter, D.F., R.C. Kochel, and J.R. Miller. 2002. Process Geomorphology, $4^{\text {th }}$ ed. New York: McGraw-Hill.

Saines, M. 1981. Errors in interpretation of ground-water level data. Ground Water Monitoring Review 1, no. 1: 56-61.

Schilling, K.E., Y.-K. Zhang, and P. Drobney. 2004. Water table fluctuations near an incised stream, Walnut Creek, Iowa. Journal of Hydrology 286: 236-248.

Schilling, K.E., Z. Li, and Y.-K. Zhang. 2006. Groundwater-surface water interaction in the riparian zone of an incised channel, Walnut Creek, Iowa. Journal of Hydrology 327: 140-150.

Schubert, J. 2002. Hydraulic aspects of riverbank filtration—field studies. Journal of Hydrology 266: 145-161.

Serrano, S., and S.R. Workman. 1998. Modeling transient stream/aquifer interaction with the non-linear Boussinesq equation and its analytical solution. Journal of Hydrology 206: 245-255.

Sheets, R.A., R.A. Darner, and B.L. Whitteberry. 2002. Lag times of bank filtration at a well field, Cincinnati, Ohio, USA. Journal of Hydrology 266: 162-174. 
Sklash, M.G., and R.N. Farvolden. 1979. The role of groundwater in storm runoff. Journal of Hydrology 43: 45-65.

Sophocleous, M., M.A. Townsend, L.D. Vogler, T.J. McClain, E.T. Marks, and G.R. Coble. 1988. Experimental studies in stream-aquifer interaction along the Arkansas River in Central Kansas-field testing and analysis. Journal of Hydrology 98: 249-273.

Stewart, M.P., P.D. Bates, M.G. Anderson, D.A. Price, and T.P. Burt. 1999. Modeling floods in hydrologically complex lowland river reaches. Journal of Hydrology 223: 85-106.

Stonestrom, D.A., and J. Constantz. 2004. Using temperature to study stream-ground water exchanges. USGS Fact Sheet 2004-3010.

Tomassoni, G. 2000. A federal statutory/regulatory/policy perspective on remedial decision-making with respect to ground-water/surface-water interaction. In Proceedings of the ground-water/surface-water interactions workshop, 13-14: EPA/542/R-00/007.

Triska, F.J., V.C. Kennedy, R.J. Avanzino, G.W. Zellweger, and K.E. Bencala. 1989. Retention and transport of nutrients in a third-order stream in northwestern California: hyporheic processes. Ecology 70, no. 6: 1893-1905.

USEPA. 2007. http://oaspub.epa.gov/tmdl/enviro_v2.wcontrol?p_id305b= RI0001002L- 03. Accessed 01/07.

Vidon, P.G.F., and A.R. Hill. 2004. Landscape controls on the hydrology of stream riparian zones. Journal of Hydrology 292: 210-228.

WeatherUnderground. 2006. http://www.weatherunderground.com/weatherstation/ WXDailyHistory.asp?ID=KRIPASCO1\&day=30\&year=2006\&month=4\&grap hspan=3month. Accessed 05/06 through 10/06.

Westbrook, S.L., J.L. Rayner, G.B. Davis, T.P. Clement, P.L. Bjerg, and S.J. Fisher. 2005. Interaction between shallow groundwater, saline surface water and contaminant discharge at a seasonally and tidally forced estuarine boundary. Journal of Hydrology 302: 255-269.

Wett, B., H. Jarosh, and K. Ingerle. 2002. Flood induced infiltration affecting a bank filtrate well at the River Enns, Austria. Journal of Hydrology 266: 222-234.

White, D.S. 1993. Perspectives on defining and delineating hyporheic zones. Journal of the North American Benthological Society 12. no. 1: 61-69. 
Winter, T.C., J.W. Harvey, O.L. Franke, and W.M. Alley. 1998. Ground water and surface water: a single resource. USGS Circular 1139.

Woessner, W.W. 2000. Stream and fluvial plain ground water interactions: rescaling hydrogeologic thought: Ground Water 38, no. 3: 423-429.

Wroblicky, G.J., M.E. Campana, H.H. Valett, and C.N. Dahm. 1998. Seasonal variation in surface-subsurface water exchange and lateral hyporheic area of two stream-aquifer systems. Water Resources Research 34, no. 3: 317-328.

Zhang, Y.-K., and K.E. Schilling. 2006. Effects of land cover on water table, soil moisture, evapotranspiration, and groundwater recharge: A field observation and analysis. Journal of Hydrology 319: 328-338. 


\section{APPENDIX I: STUDY SITE}

\section{Study site}

\subsection{Climate}

Long-term temperature monitoring data is available from T.F. Green Airport located in Warwick, RI, $35 \mathrm{~km}$ southeast of Pascoag. Mean annual temperature from $1961-90$ was $10.2^{\circ} \mathrm{C}$ with a mean monthly temperature range of $-2.3^{\circ} \mathrm{C}$ to $22.6^{\circ} \mathrm{C}$ with the low in January and the high in July (Barlow 2003). Precipitation data are available for the period from 1957-99 for Woonsocket, RI, $17 \mathrm{~km}$ east of Pascoag. Average annual precipitation was $122 \mathrm{~cm} / \mathrm{yr}$ with an average monthly precipitation of 8.9 to $11.7 \mathrm{~cm} / \mathrm{mo}$ with the low in June and the high in November. The more recent period from 1995-99 indicates a slight increase in precipitation with the range increasing to 7.9 to $15.2 \mathrm{~cm} / \mathrm{mo}$ and the low and high months shifting to August and January, respectively (Barlow 2003).

\subsection{Bedrock}

The bedrock augen granite gneiss is typically medium-to-coarse-grained with large feldspar porphyroclasts, and is generally variable in compositions (mostly quartz, feldspar, biotite, hornblende, and other accessory minerals). The second, less common rock unit is generally fine-to-medium-grained granite gneiss that lacks porphyroclasts, and is more quartz-rich than the augen granite gneiss (Hermes et al. 1995; Quinn 1967). This unite forms a narrow gradational lens that extends from the source zone into the middle of the site. Both rock units are typically massive but display lineation and foliation that is locally very strong. Both units are highly fractured with fracture locations dependent on the zones of lineation and foliation. 
A fracture study by Allen and Boving (2006) found the dominant trend of mineral lineation is approximately $\mathrm{N} 2^{\circ} \mathrm{E}$ and plunges $10^{\circ}$ north. Dominant fractures strike nearly north-south with an average dip of $65^{\circ} \mathrm{E}$ (Figure 21). Another less dominant fracture orientation trends $\mathrm{N} 75^{\circ} \mathrm{W}$ and dips $75^{\circ}$ south. The frequency of these fractures may be localized into fracture zones, with the rock units being more massive between these zones. Other fracture orientations occur, but their frequency and importance appear to be less significant. Also, orthogonal fractures that trend along the same dominant strike direction but dip much more shallowly were detected.

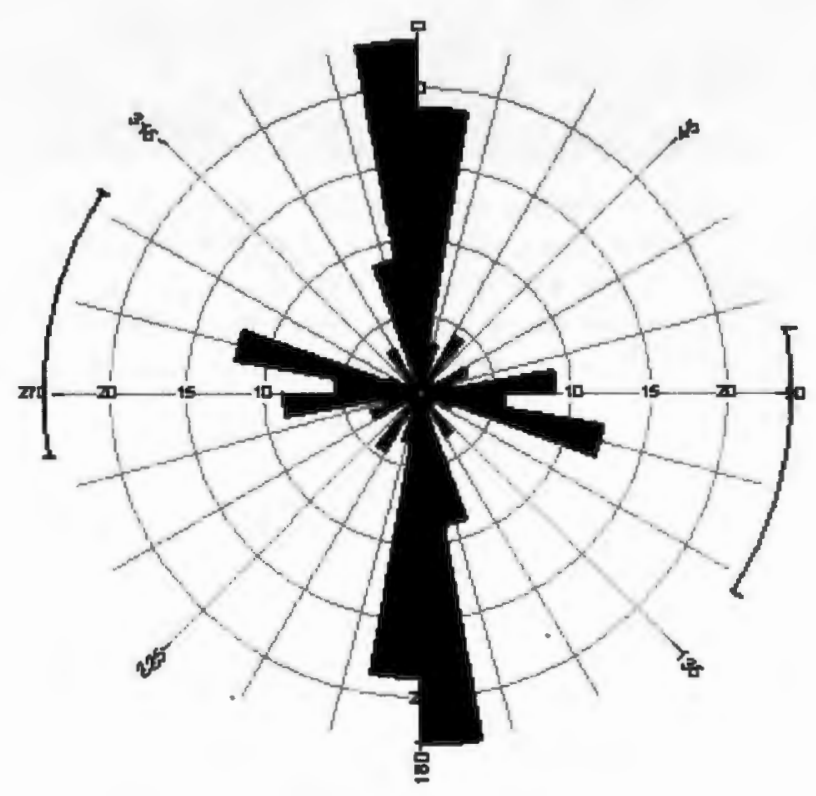

Figure 21. Rose diagram of bedrock fracture trends collected from outcrops in and around Pascoag (Allen and Boving 2006).

\subsection{Historical Photographs}

Photographs of the textile factory that was located at the study site from the 1800 s through around 1960 (Figure 22 and Figure 23). 


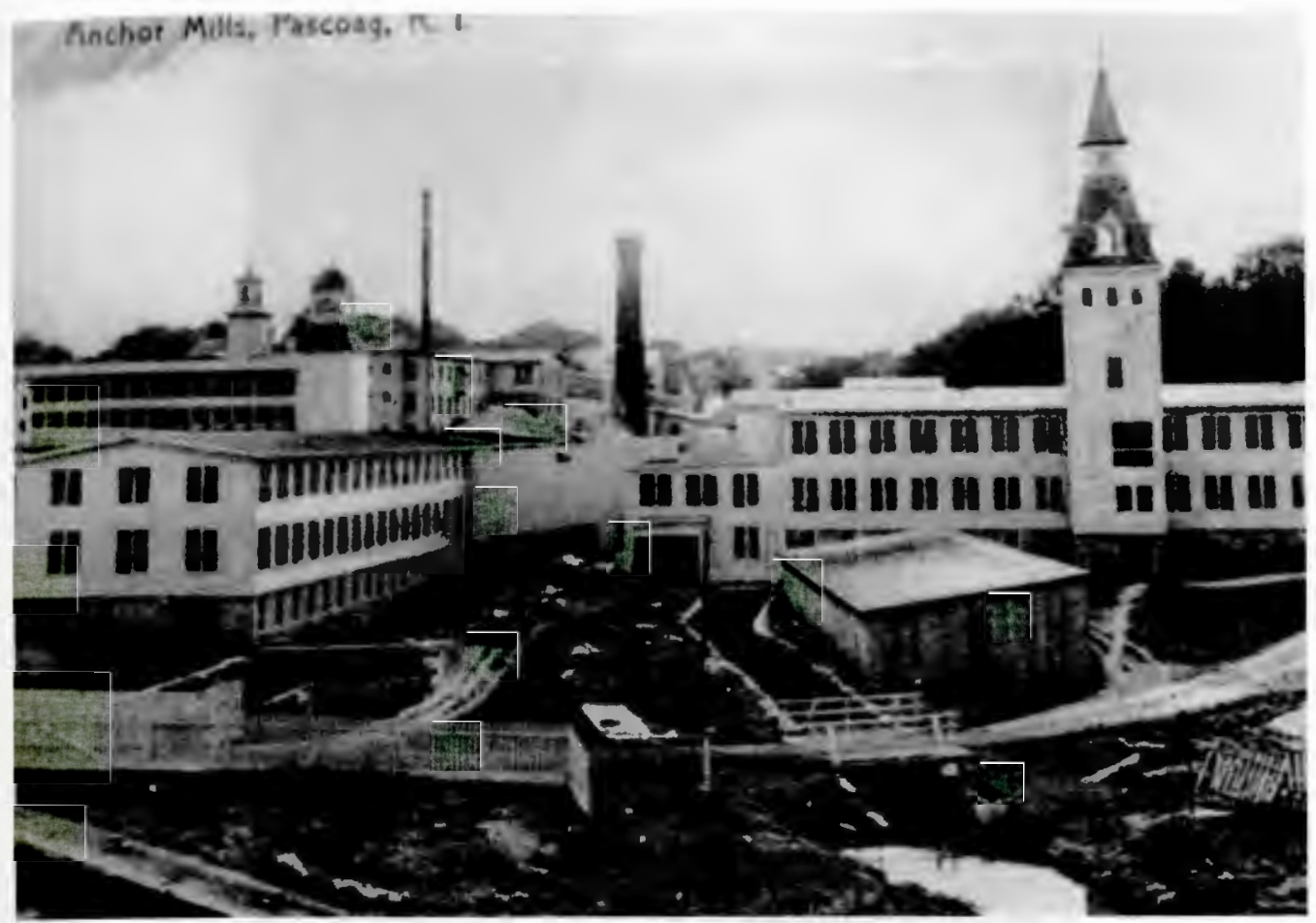

Figure 22. Former textile factory at the site. Photograph taken looking south from a train bridge that spanned the river. The Pascoag River currently flows through the channel in the center of the photograph. Notice the channel on the left in front of the building. This channel has since been filled. The wells for this thesis were located in the foreground just past the bridge over channel before the bend. (Burrillville Preservation and Historical Society 2005). 


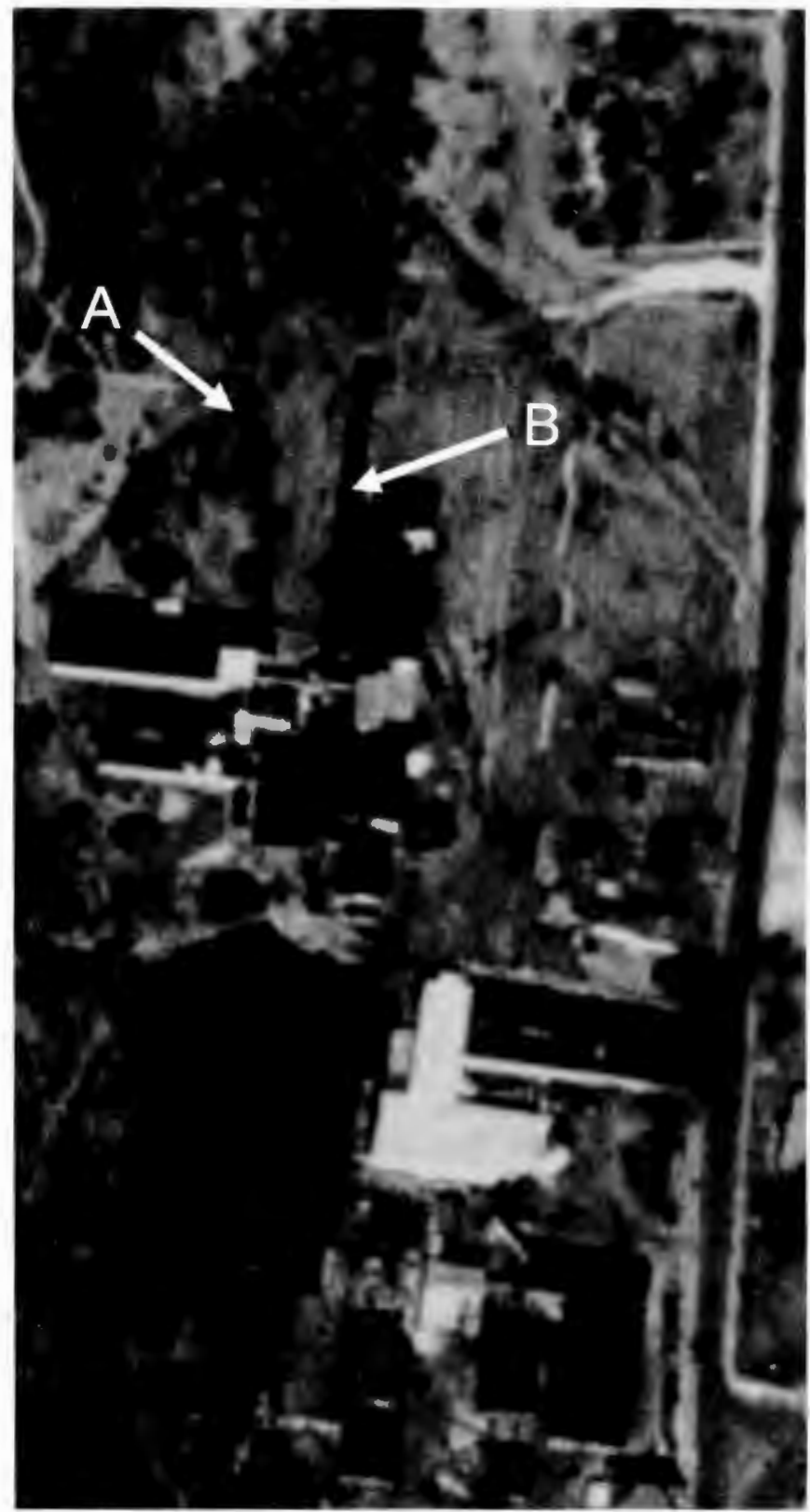

Figure 23. 1939 Aerial photograph of the textile factory (Rhode Island Geographic Information Systems 2006). $A$ points to the current channel of the Pascoag River. $B$ shows the location of the channel that has since been filled in. (North is up). 


\section{APPENDIX II: METHODS}

\section{Field Methods}

\subsection{Well Installation and Surveying}

The four wells already present in this area prior to this study, MW 18, MW 18D, MW 44, and MW 56 all have longer screens than the wells installed for this study. All

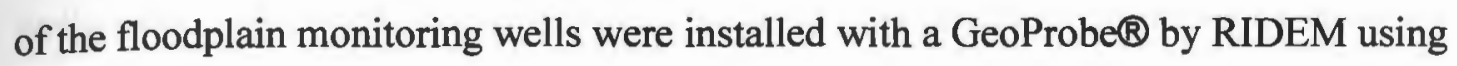
the following method. First, depth to refusal was determined by pushing sections of $3.81 \mathrm{~cm}$ steel rod into the ground until refusal was reached. It is unclear if refusal is bedrock, dense till, or boulders; dense till is suspected. These rods were removed and a hollow $7.62 \mathrm{~cm}$ rod fitted with a disposable point was pushed to the desired depth in a new hole. A $2.54 \mathrm{~cm}$ PVC monitoring well was inserted into the rod and coarse sand annular fill was poured into the bottom of the well around the screen. The disposable point was then detached and the rod carefully removed while adding sand pack around the well. At approximately $1.5 \mathrm{~m}$, bentonite was added to seal the well followed by sand on top. Short sections of larger diameter PVC pipe were fitted around the monitoring well to allow for datalogger cables and PVC pump tubing to remain in the well. This also allowed the wells to be locked for security. Wells were developed by surging with a check valve to remove sediment.

The wells in the river, JA 1 R and JA $1 \mathrm{RB}$, had to be installed securely to prevent destruction during high river stage. The well consisted of a $1.5 \mathrm{~m}$ long by $10 \mathrm{~cm}$ steel casing fitted with two interior wells and was sealed at the bottom. The riverbed well was inserted through a sealed fitting and a $0.3 \mathrm{~m}$ screen extended into the riverbed. The purpose of the river well was to house the pressure transducer monitoring river 
stage and was only screened through the river. The steel casing was perforated with approximately fifty $1 \mathrm{~cm}$ holes to allow interaction with the river. The well unit was installed in the river by digging a hole in the riverbed and was attached to the river channel wall with steel rods. Due to the extremely high river stage, well extensions were installed to bring the height of the wells above the river surface. Other riverbed wells were installed by pushing the PVC well into the riverbed and hitting with a rubber mallet until refusal.

The four wells already present in the study area were previously surveyed for top of casing elevation by RIDEM. The additional wells installed for this study were surveyed using the known elevation from MW 44. All wells, including the already existing wells, were surveyed with a Topcon AT-G6 Auto Level using a leveling rod. Instrument error is $\pm 2 \mathrm{~mm}$ at $1 \mathrm{~km}$, and total error is probably less than $1 \mathrm{~cm}$ (Laserbeams.com 2006).

\subsection{Slug Testing}

Bouwer-Rice falling head slug tests were performed on all wells to determine hydraulic conductivity. The test was performed by placing a pressure transducer at the bottom of the well and then inserting a solid slug. Manual depth to water measurements were also taken before and after the test. The test measured the response of the slug insertion and the slug removal after waiting for the water table to respond. Generally, the slug removal data provided a better response curve. Data was transferred to AQTESOLV software to calculate hydraulic conductivity using the slug testing wizard and the appropriate input parameters. 


\subsection{Equipment and Specifications}

Table 12 lists the equipment brand and specifications for field instruments and data collections devices.

Table 12. List of equipment and specifications used for field work and data collection.

\begin{tabular}{|c|c|c|c|c|}
\hline Instrument & Model & Calibration Type & Accuracy & Other \\
\hline $\begin{array}{l}\text { Dissolved } \\
\text { Oxygen }\end{array}$ & YSI $550 \mathrm{~A}$ & $\begin{array}{l}\text { Internal calibration } \\
\text { with moist sponge }\end{array}$ & NA & \\
\hline $\mathrm{pH}$ & $\begin{array}{l}\text { Thermo Orion } 210 \\
\mathrm{~A}+\end{array}$ & $\begin{array}{l}2 \text { point external } \\
\text { calibration with pH } \\
4 \text { and } 7 \text { buffer } \\
\text { solutions (Wilkem } \\
\text { Scientific) }\end{array}$ & NA & \\
\hline $\begin{array}{l}\text { Electrical } \\
\text { Conductivity }\end{array}$ & YSI EC 300 & $\begin{array}{l}1 \text { point external } \\
\text { calibration with } \\
1413 \mu \mathrm{S} \mathrm{KCl} \\
\text { solution made from } \\
\text { Certified ACS grade } \\
\text { salts }\end{array}$ & $\begin{array}{l}\text { Temperature verified } \\
\text { with NIST thermometer } \\
\text { to } 1^{\circ} \mathrm{C}\end{array}$ & $\begin{array}{l}\text { Temperature } \\
\text { compensated, used } \\
\text { for manual well } \\
\text { temperature }\end{array}$ \\
\hline $\begin{array}{l}\text { Temperature } \\
\text { Sensors }\end{array}$ & $\begin{array}{l}\text { Dallas } \\
\text { Semiconductor } \\
\text { Thermochron } \\
\text { iButton® } \\
\text { DS1921Z }\end{array}$ & Factory calibrated & $\begin{array}{l}\text { Manufacturer specifies } \\
\text { to } \pm 1^{\circ} \mathrm{C} \text {, Precison for } \\
\text { all verified to } 0.7^{\circ} \mathrm{C} \text { at } \\
\text { high range, and } 0.2^{\circ} \mathrm{C} \text { at } \\
\text { low range }\end{array}$ & $\begin{array}{l}\text { Range: }-5 \text { to } 26^{\circ} \mathrm{C} \text {, } \\
\text { Resolution: } 0.125^{\circ} \mathrm{C}\end{array}$ \\
\hline $\begin{array}{l}\text { Pressure } \\
\text { Transducer/ } \\
\text { Datalogger }\end{array}$ & $\begin{array}{l}\text { In-Situ } \\
\text { MiniTROLL } \\
\text { Standard and } \\
\text { Professional }\end{array}$ & Factory calibrated & $\begin{array}{l}\text { At } 21 \mathrm{~m} \text { range ( } 30 \\
\mathrm{psi}) / 0.1 \% \text { full scale, } \\
0.05 \% \text { at } 15^{\circ} \mathrm{C}\end{array}$ & $\begin{array}{l}\text { Resolution: } 1 \mathrm{~mm} \text {, } \\
\text { Operated in surface } \\
\text { mode, vented and } \\
\text { temperature } \\
\text { compensated }\end{array}$ \\
\hline $\begin{array}{l}\text { Temperature/ } \\
\text { Datalogger }\end{array}$ & $\begin{array}{l}\text { In-Situ } \\
\text { MiniTROLL } \\
\text { Professional }\end{array}$ & Factory calibrated & $\begin{array}{l}\text { Manufacturer specifies } \\
\text { to } \pm 0.25^{\circ} \mathrm{C} \text {, verified to } \\
1^{\circ} \mathrm{C} \text { with NIST } \\
\text { thermometer }\end{array}$ & Range: -5 to $50^{\circ} \mathrm{C}$, \\
\hline Interface Probe & $\begin{array}{l}\text { Oil recovery } \\
\text { Systems (ORS) }\end{array}$ & Factory calibrated & In water to $3 \mathrm{~mm}$ & \\
\hline
\end{tabular}




\subsection{River Discharge}

River discharge was measured during the study by the float method due to the simple dimensions of the river channel and regular flow (Hudson 1993). Also, only an approximate measurement of discharge was required. The method consisted of first measuring a straight $10 \mathrm{~m}$ section of the river at the study site. Average channel width and depth were measured at $0 \mathrm{~m}, 5 \mathrm{~m}$, and $10 \mathrm{~m}$ by taking six depth measurements across a river channel transect. Average velocity was determined by measuring ten replicates of travel time of a $10 \mathrm{~cm} \mathrm{x} 9 \mathrm{~cm} \times 5 \mathrm{~cm}$ block of wood over the $10 \mathrm{~m}$ section. From this, discharge was calculated by (Oklahoma Water Resources Board 2004):

$$
Q_{\text {riv }}=A \times V_{\text {avg }}
$$

$$
\text { Where: } \begin{aligned}
Q_{\text {riv }} & =\text { River Discharge }\left(\mathrm{m}^{3} / \mathrm{sec}\right), \\
A & =\text { Cross Sectional Area }\left(\mathrm{m}^{2}\right), \\
V_{\text {avg }} & =0.85 \times \text { Measured Surface Velocity }(\mathrm{m} / \mathrm{sec})
\end{aligned}
$$

This procedure was repeated at various river stages in order to construct a river discharge ratings curve.

\section{Laboratory Methods}

\subsection{Volatile Organics Analysis}


Table 13. GC/MS and purge and trap operating parameters.

\begin{tabular}{|c|c|c|c|c|}
\hline & Equipment & Method & & Parameters \\
\hline GC & $\begin{array}{l}\text { Shimadzu GC 17A } \\
\text { Split/Splitless injector } \\
\text {-> Straight liner w/wool } \\
\text { Rtx-VMS } 30 \mathrm{~m} \times 0.25 \mathrm{~mm} \\
\times 0.25 \mu \mathrm{m}\end{array}$ & \multirow[b]{2}{*}{$\begin{array}{c}\text { Purgeable } \\
\text { volatiles method } \\
\text { modified after } \\
\text { EPA Method } 624\end{array}$} & $\begin{array}{l}\text { Injector Temp: } \\
\text { SplitRatio: } \\
\text { Total flow: } \\
\text { Oven Program: } \\
\\
\\
\text { Pressure Program: } \\
\text { (constant velocity) }\end{array}$ & $\begin{array}{l}250^{\circ} \mathrm{C} \\
20: 1 \\
28.5 \mathrm{~mL} / \mathrm{min} \\
\text { Initial Temp } 40^{\circ} \mathrm{C} \text { (hold } 2 \mathrm{~min} \text { ) } \\
\text { to } 130^{\circ} \mathrm{C} @ 6^{\circ} \mathrm{C} / \mathrm{min} \\
\text { to } 210^{\circ} \mathrm{C} @ 35^{\circ} \mathrm{C} / \mathrm{min} \text { (hold } 1 \\
\text { min) } \\
\text { Initial Pressure } 70 \mathrm{kPa} \text { (hold } 2 \\
\text { min) } \\
\text { to } 109.8 \mathrm{kPa} @ 2.7 \mathrm{kPa} / \mathrm{min} \\
\text { to } 144.4 \mathrm{kPa} @ 14.6 \mathrm{kPa} / \mathrm{min}\end{array}$ \\
\hline MS & Shimadzu QP5000 & & $\begin{array}{l}\text { Interface Temp: } \\
\text { Detector Voltage: } \\
\text { Scan Parameters } \\
\text { Solvent Cut: } \\
\text { Acquisition Time: } \\
\text { Mass Range: } \\
\text { Interval: } \\
\text { Threshold: } \\
\text { Integration Parameters } \\
\text { Width: } \\
\text { Slope: } \\
\text { Drift: } \\
\text { T.DBL: }\end{array}$ & $\begin{array}{l}280^{\circ} \mathrm{C} \\
1.00 \mathrm{kV} \\
2.5 \mathrm{~min} \\
2.6-20.29 \mathrm{~min} \\
45-260 \mathrm{M} / \mathrm{Z} \\
0.22 \mathrm{sec} \\
1000 \\
\mathrm{~s} \\
2.00 \mathrm{sec} \\
500 * 1000 / \mathrm{min} \\
0 * 1000 / \mathrm{min} \\
1000 \mathrm{~min}\end{array}$ \\
\hline $\begin{array}{l}\text { Purge } \\
\text { and } \\
\text { Trap }\end{array}$ & $\begin{array}{l}\text { OI Analytical } 4660 \\
\text { Tenax \#10 Trap } \\
5 \text { mL Sparge Vessel }\end{array}$ & $\begin{array}{l}\text { Modified after } \\
\text { EPA Method } \\
\text { 5030B }\end{array}$ & $\begin{array}{l}\text { Sparge Mount Temp: } \\
\text { Purge Time: } \\
\text { Purge Trap Temp: } \\
\text { Water Management: } 1 \\
\text { Desorb Preheat: } \\
\text { Desorb Time: } \\
\text { Trap Desorb Temp: } \\
\text { Bake Time: } \\
\text { Trap Bake Temp: }\end{array}$ & $\begin{array}{l}\text { ambient } \\
11 \mathrm{~min} \\
\text { ambient } \\
100^{\circ} \mathrm{C} \\
180^{\circ} \mathrm{C} \\
1.5 \mathrm{~min} \\
190^{\circ} \mathrm{C} \\
6 \mathrm{~min} \\
210^{\circ} \mathrm{C}\end{array}$ \\
\hline
\end{tabular}

All GC/MS and purge and trap operating parameters are listed in Table 13. The overall method was similar to EPA Method 624 which is a purgeable volatiles method capable of low $\mu \mathrm{g} / \mathrm{L}$ MTBE detection. The GC/MS was internally tuned daily with PFTBA tuning standard prior to running samples to verify mass resolution. The tune was then checked by injecting a BFB external tuning standard to check relative peak 
intensities. Instrument calibration was performed with six external standards at the following concentrations $2,10,20,40,80$, and $160 \mu \mathrm{g} / \mathrm{L}$. Each standard and all samples were prepared and introduced in the same manner through the purge and trap device. Deionized water or the sample was carefully transferred from the VOA vial into a clean $5 \mathrm{~mL}$ purge and trap luer-lock syringe and adjusted to $5 \mathrm{~mL}$. For each standard, an appropriate amount of $10 \mathrm{mg} / \mathrm{L}$ volatiles working standard and BFB surrogate standard (for samples only surrogate was added) was added to the syringe through the luer-lock opening (Table 14). The standard or sample was then transferred though the injection port on the purge and trap into the $5 \mathrm{~mL}$ sparge vessel. After helium purging and purge and trap method completion, the extracted volatiles were transferred from the trap to the GC column for the start of the analytical method. The sparge vessel and the purge and trap syringe were rinsed thoroughly between samples.

Table 14. Stock standard vendor and concentrations.

\begin{tabular}{|l|l|l|l|}
\hline Standard/Reagent & \multicolumn{1}{|c|}{ Manufacturer } & Stock Concentration & Working Concentration \\
\hline Volatiles & SPEX CertiPrep P-GAS & $2,000 \mathrm{mg} / \mathrm{L}$ & $10 \mathrm{mg} / \mathrm{L}$ \\
BFB & Ultra Scientific STS-110N-1 & $2,000 \mathrm{mg} / \mathrm{L}$ & $10 \mathrm{mg} / \mathrm{L}$ \\
Methanol & $\begin{array}{l}\text { Fisher Scientific Purge \& Trap } \\
\text { Grade Methanol }\end{array}$ & NA & NA \\
\hline
\end{tabular}

Standards were prepared from purchased certified standards in Purge and Trap Grade Methanol. Working standards were stored in the freezer and replaced when quality control indicated standard degradation. Calibration was performed by linear regression and was accepted if $R^{2}$ was $>0.995$. Calibration verifications were analyzed after calibration, after every ten samples, and at the end of a run. Acceptance criteria range was $\pm 15 \%$ in general, but a daily precision of $\pm 5 \%$ was preferred in 
order to minimize relative error associated with response variability. Method blanks spiked with surrogate standard were analyzed at the start of each run. Many dilutions were required and were prepared in $10 \mathrm{~mL}$ volumetric flasks.

A minimum detection limit (MDL) study was completed to determine the analytical capabilities of the instrument. The study was completed by analyzing 7 replicates of deionzed water spiked with $5 \mathrm{ug} / \mathrm{L}$ of the volatiles standard. The MDL was calculated by multiplying the standard deviation of the replicates by the corresponding student's t-statistic. The MDL is the concentration at which there is $95 \%$ confidence that the concentration is not zero. If quantified, values below this must be reported as "not detected". Values between the MDL and the lowest standard (the reporting limit) must be reported as tentative values but can be considered reliable if a blank passes.

\subsection{Ion Analysis}

Cations and anions were analyzed by ion chromatography on a DX 120 (Dionex Corporation). All calibration standards were prepared from $250 \mathrm{~mL}$ intermediate standards which were prepared from $1000 \mathrm{mg} / \mathrm{L}$ stock standards. Stock standards were made from certified granular salts containing the analyte of interest. All samples were filtered with a $0.45 \mu \mathrm{m}$ filter prior to analysis. Anion eluent was made by dissolving $0.19 \mathrm{~g}$ of sodium carbonate and $0.142 \mathrm{~g}$ of sodium bicarbonate to $1 \mathrm{~L}$. Cation eluent was made by diluting $28 \mathrm{~mL}$ of $1 \mathrm{~N}$ sulfuric acid to $1 \mathrm{~L}$.

Calibration standard levels for anions and cations are listed in Table 15. Anion calibration was four-point while cation calibration was three-point. Both calibrations were accepted if the $\mathrm{R}^{2}$ was $>0.992$ or better and an initial calibration control standard 
Table 15. Anion and cation calibration levels.

\begin{tabular}{|c|c|c|c|c|c|c|c|c|c|}
\hline & \multirow{2}{*}{$\begin{array}{c}\text { Calibration } \\
\text { Level }\end{array}$} & \multicolumn{4}{|c|}{ Anions (mg/L) } & \multicolumn{4}{|c|}{ Cations (mg/L) } \\
\hline & & Chloride & Nitrate & Phosphate & Sulfate & Sodium & Potassium & Magnesium & Calcium \\
\hline \multirow{4}{*}{ 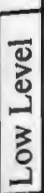 } & LL1 & 1 & 0.5 & 0.25 & 1 & 1 & 0.25 & 0.25 & 1 \\
\hline & LL2 & 4 & 2 & 1 & 4 & 10 & 2.5 & 2.5 & 10 \\
\hline & LL3 & 10 & 5 & 2.5 & 10 & 20 & 5 & 5 & 20 \\
\hline & LL4 & 20 & 10 & 5 & 20 & NA & NA & NA & NA \\
\hline \multirow{4}{*}{ 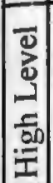 } & HL1 & 20 & NA & NA & NA & 20 & 5 & 5 & 20 \\
\hline & HL2 & 50 & NA & NA & NA & 50 & 10 & 10 & 50 \\
\hline & HL3 & 80 & NA & NA & NA & 120 & 15 & 15 & 120 \\
\hline & HL4 & 120 & NA & NA & NA & NA & $\mathrm{NA}$ & NA & NA \\
\hline
\end{tabular}

passed $( \pm 15 \%)$. Addition calibration verification standards were analyzed after ten samples and as the last sample of every run. Periodic method blanks and duplicates were analyzed to determine reproducibility and system performance.

Table 16. Anion and cation calculated MDLs.

\begin{tabular}{|l|c|}
\hline \multicolumn{1}{|c|}{ Target Ion } & $\begin{array}{c}\text { Minimum } \\
\text { Detection Limit } \\
\text { (mg/L) }\end{array}$ \\
\hline Chloride & 0.09 \\
Nitrate (as nitrate) & 0.11 \\
Phosphate (as phosphate) & 0.17 \\
Sulfate (as sulfate) & 0.22 \\
Sodium & 0.41 \\
Potassium & 0.29 \\
Magnesium & 0.07 \\
Calcium & 0.19 \\
\hline
\end{tabular}

Blanks determined any background system contamination and the method reporting limit. An MDL study was also completed for both anions and cations (Table 16). The calculated MDLs for chloride, nitrate, and magnesium may be lower than instrument analytical capabilities and can only be used as rough guidelines.

\section{Precipitation and Temperature}

A combination of weather stations was required to accurately determine the average daily precipitation and temperature. This was because of inconsistencies in 
individual datasets and because the Pascoag Weather Underground station $(0.5 \mathrm{~km}$ from study site) came online April 5, 2006 (Weather Underground 2006). Once online, there were times when the station was offline for short periods and no data was collected. When service returned, any precipitation that had accumulated was registered as a single event. This also skewed the average daily temperature. Accompanying datasets were obtained from the National Oceanic \& Atmospheric Administration (NOAA) website (NCDC 2006) for Woonsocket, RI, North Foster, RI, and Worcester Regional Airport, MA, at respective distances of $17 \mathrm{~km}, 13 \mathrm{~km}$, and 42 $\mathrm{km}$ from the central study site in Pascoag. Values obtained from these stations were averaged to obtain an approximate value for Pascoag. River hydrographs were checked for single events and where inconsistencies occurred, the Pascoag Weather Underground data was typically used. 


\section{APPENDIX III: RESULTS AND DISCUSSION}

\section{Slug Tests}

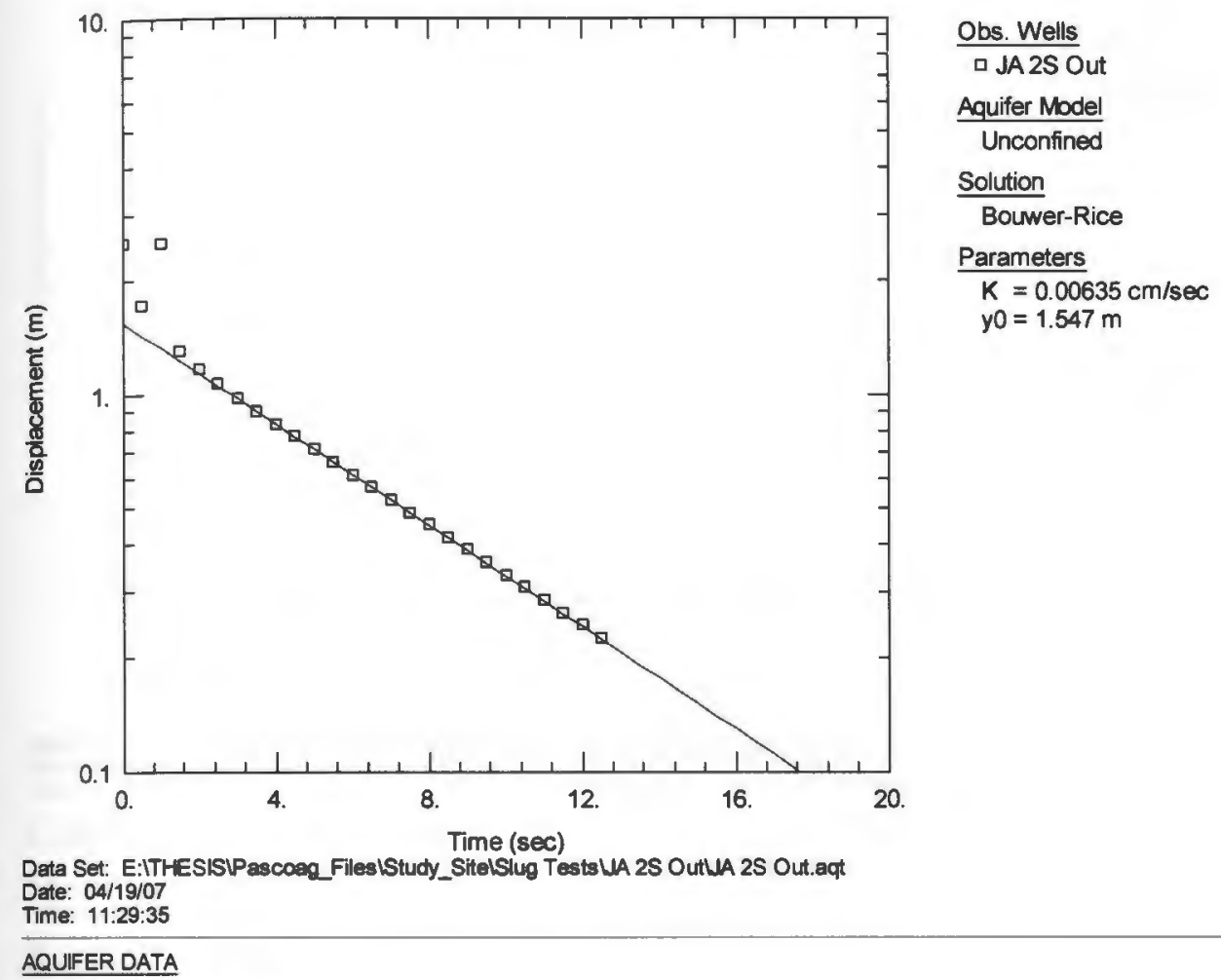

Saturated Thickness: $6.634 \mathrm{~m}$

Anisotropy Ratio $(\mathrm{K} / \mathrm{Kr})$ : 1.

\section{SLUG TEST WELL DATA}

Initial Displacement: $2.528 \mathrm{~m}$

Casing Radius: $0.0127 \mathrm{~m}$

Wellbore Radius: $0.0381 \mathrm{~m}$

Well Skin Radius: $0.0381 \mathrm{~m}$

Screen Length: $0.3048 \mathrm{~m}$

Total Well Penetration Depth: $2.36 \mathrm{~m}$

No. of observations: 25

Observation Data

Time (sec) Displacement (m) Time (sec) Displacement (m) Time (sec) Displacement (m)

$\begin{array}{ccccc}0.5 & 1.734 & 5 . & 0.715 \\ 1 . & 2.528 & 5.5 & 0.662 \\ 1.5 & 1.299 & 6 . & 0.612 \\ 2 . & 1.164 & 6.5 & 0.567 \\ 2.5 & 1.065 & 7 . & 0.525 \\ 3 . & 0.978 & 7.5 & 0.486 \\ 3.5 & 0.903 & 8 . & 0.45 \\ 4 . & 0.834 & 8.5 & 0.417 \\ 4.5 & 0.773 & 9 . & 0.387\end{array}$

SOLUTION

Aquifer Model: Unconfined

Solution Method: Bouwer-Rice

VSUAL ESTIMATIONRESULTS

Estimated Parameters

\begin{tabular}{ccl} 
Parameter & Estimate & \\
\hline K & $0.00635^{\circ}$ & $\mathrm{cm} / \mathrm{sec}$ \\
yo & 1.547 & $\mathrm{~m}$
\end{tabular}




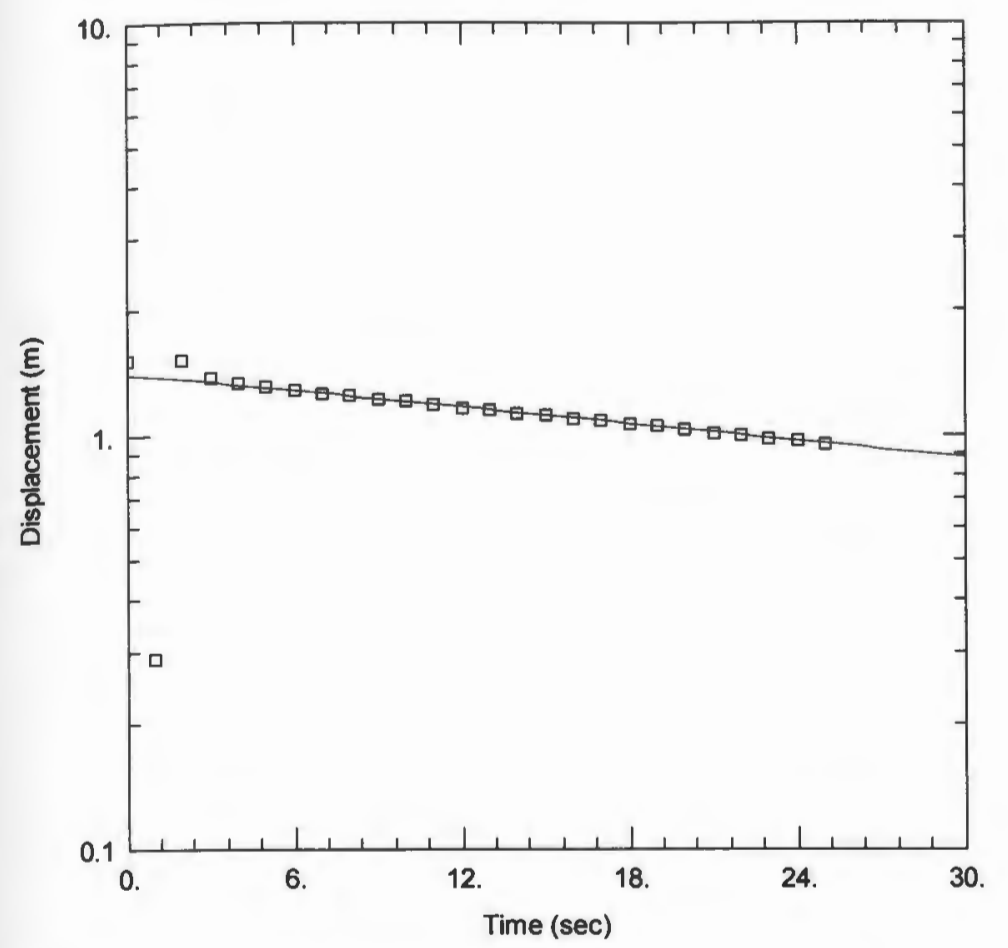

Obs. Wells

口 JA 2D Out

Aquifer Model

Unconfined

Solution

Bouwer-Rice

Parameters

$K=0.0007316 \mathrm{~cm} / \mathrm{sec}$

$\mathrm{y} 0=1.402 \mathrm{~m}$

Data Set: E:ITHESISWascoag_FilesiStudy_SitelSlug TestsUA 2D OutLA 2D Out.aqt

Date: $04 / 19 / 07$

Time: 11:26:05

AQUIFER DATA

Saturated Thickness: $6.57 \mathrm{~m}$

Anisotropy Ratio $\left(\mathrm{K}_{\mathrm{z}} / \mathrm{K} \mathrm{r}\right)$ : 1.

\section{SLUG TEST WELDATA}

Initial Displacement: $1.52 \mathrm{~m}$

Casing Radius: $0.0127 \mathrm{~m}$

Wellbore Radius: $0.0381 \mathrm{~m}$

Well Skin Radius: $0.0381 \mathrm{~m}$

Screen Length: $0.3048 \mathrm{~m}$

Total Well Penetration Depth: $5.35 \mathrm{~m}$

№. of observations: 25

Observation Data

Time (sec) Displacement (m) Time (sec) Displecement (m) Time (sec) Displacement (m)

$\begin{array}{cccccc}1 . & 0.288 & 10 . & 1.198 & 19 . & 1.041 \\ 2 . & 1.52 & 11 . & 1.178 & 20 . & 1.025 \\ 3 . & 1.367 & 12 . & 1.16 & 21 . & 1.01 \\ 4 . & 1.328 & 13 . & 1.142 & 22 . & 0.994 \\ 5 . & 1.301 & 14 . & 1.125 & 23 . & 0.979 \\ 6 . & 1.278 & 15 . & 1.107 & 24 . & 0.964 \\ 7 . & 1.257 & 16 . & 1.091 & 25 . & 0.95 \\ 8 . & 1.237 & 17 . & 1.074 & & \end{array}$

SOLUTION

Aquifer Model: Unconfined

Solution Mathod: Bouwer-Rice

VSUAL ESTIMATIONRESULTS

Estimated Parameters

\begin{tabular}{ccc} 
Parameter & Estimate & \\
\hline $\mathrm{K}$ & 0.0007316 & $\mathrm{~cm} / \mathrm{sec}$ \\
yo & 1.402 & $\mathrm{~m}$
\end{tabular}




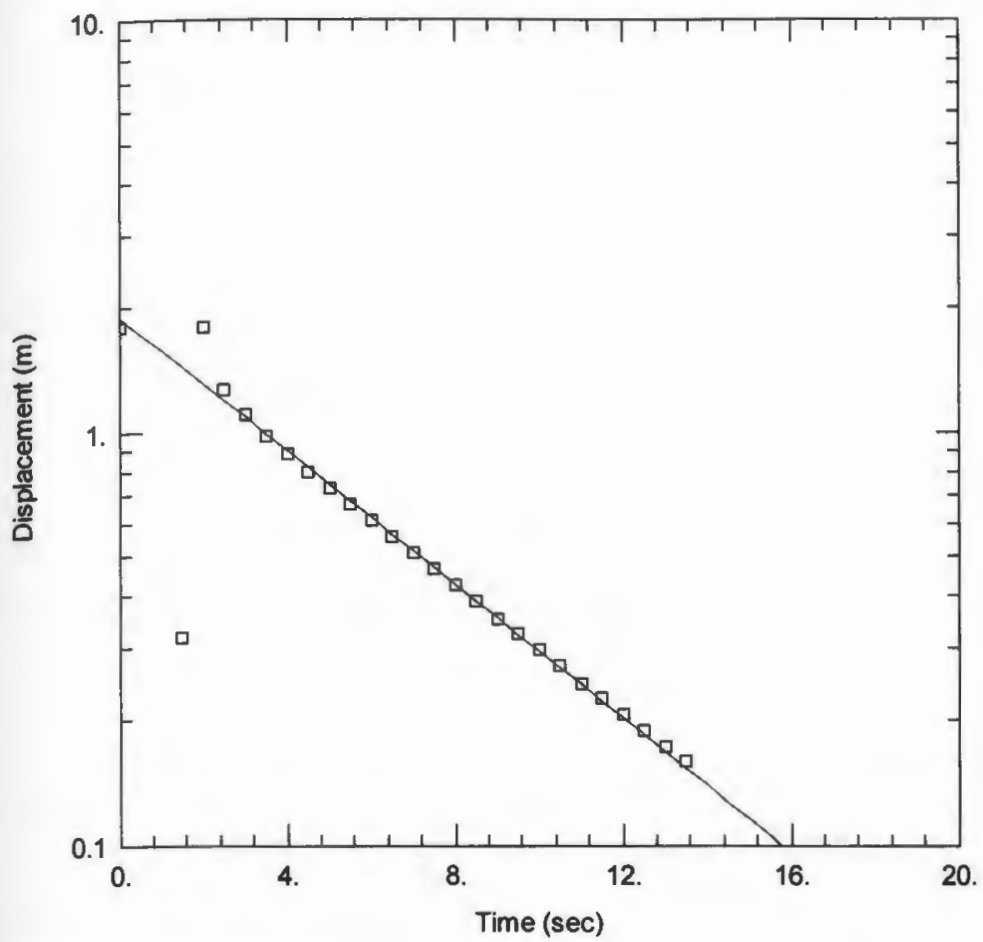

Obs. Wells

口 JA 3S Out

Aquifer Model

Unconfined

Solution

Bouwer-Rice

Parameters

$\mathrm{K}=0.007691 \mathrm{~cm} / \mathrm{sec}$

$\mathrm{y} 0=1.897 \mathrm{~m}$

Data Set: E:ITHESISPascoag_Files IStudy_SitelSlug TestsWA 3S OutVA 3S Out.aqt

Date: 04/19/07

Time: 11:36:00

AQUIFER DATA

Saturated Thickness: $5.95 \mathrm{~m}$

Anisotropy Ratio (Kz/Kr): 1.

\section{SLUG TEST WEL DATA}

Initial Displacement: $1.796 \mathrm{~m}$

Casing Radius: $0.0127 \mathrm{~m}$

Wellbore Radius: $0.0381 \mathrm{~m}$

Well Skin Radius: $0.0381 \mathrm{~m}$

Screen Length: $0.3048 \mathrm{~m}$

Total Well Penetration Depth: $2.303 \mathrm{~m}$

No. of observations: 25

Observation Data

Time (sec) Displacement (m) Time (sec) Displacement (m) Time (sec) Displacement (m)

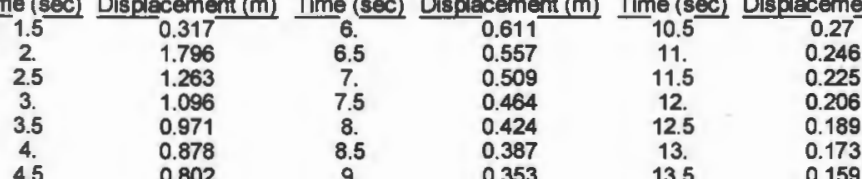

SOLUTION

Aquifer Model: Unconfined

Solution Method: Bouwer-Rice

MSUAL ESTIMATIONRESULTS

Estimated Parameters

$\begin{array}{ccc}\text { Parameter } & \text { Estimate } & \\ \mathrm{K} & 0.007691 & \mathrm{~cm} / \mathrm{sec} \\ \text { yo } & 1.897 & \mathrm{~m}\end{array}$




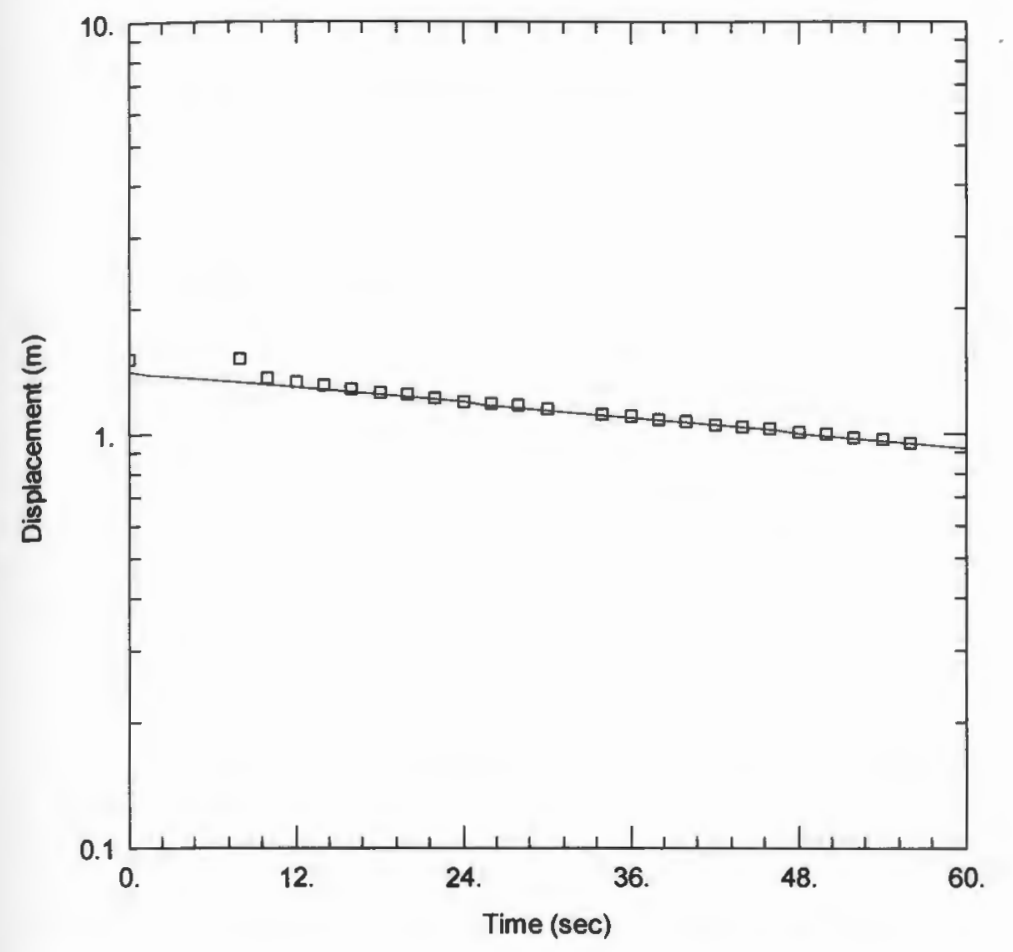

Obs. Wells 口 JA 3D Out

Aquifer Model Unconfined

Solution

Bouwer-Rice

Parameters

$K=0.0003484 \mathrm{~cm} / \mathrm{sec}$ $\mathrm{y} 0=1.406 \mathrm{~m}$

Data Set: E:ITHESISIPascoag_FilesIStudy_SitelSlug TestsLA 3D OutJA 3D Out.aqt

Date: $04 / 19 / 07$

Time: 11:40:37

\section{AQUIFER DATA}

Saturated Thickness: $5.96 \mathrm{~m}$

Anisotropy Ratio (Kz/Kr): 1.

\section{SLUG TEST WELL DATA}

Initial Displacement: $1.521 \mathrm{~m}$

Casing Radius: $0.0127 \mathrm{~m}$

Wellbore Radius: $0.0381 \mathrm{~m}$

Well Skin Radius: $0.0381 \mathrm{~m}$

Screen Length: $0.3048 \mathrm{~m}$

Total Well Penetration Depth: $5.36 \mathrm{~m}$

No. of observations: 24

Observation Data

Time (sec) Displacement (m) Time (sec) Displacement (m) Time (sec) Displacement (m)

$\begin{array}{ccccccc}8 . & 1.521 & 24 & 1.197 & & 42 . & 1.05 \\ 10 . & 1.361 & 26 . & 1.179 & 44 . & 1.036 \\ 12 . & 1.325 & 28 . & 1.163 & 46 . & 1.021 \\ 14 . & 1.3 & 30 . & 1.145 & 48 . & 1.006 \\ 16 . & 1.276 & 34 . & 1.113 & 50 . & 0.991 \\ 18 . & 1.255 & 36 . & 1.097 & 52 . & 0.978 \\ 20 . & 1.235 & 38 . & 1.081 & 54 . & 0.964 \\ 22 . & 1.216 & 40 . & 1.065 & 56 . & 0.95\end{array}$

\section{SOLUTON}

Aquifer Model: Unconfined

Solution Method: Bouwer-Rice

\section{USUAL ESTIMATION RESULTS}

\section{Estimated Parameters}

$\begin{array}{ccl}\text { Parameter } & \begin{array}{c}\text { Estimate } \\ K \\ \text { yo }\end{array} & \begin{array}{c}0.0003484 \\ \mathrm{~cm} / \mathrm{sec}\end{array} \\ 1.406 & \mathrm{~m}\end{array}$




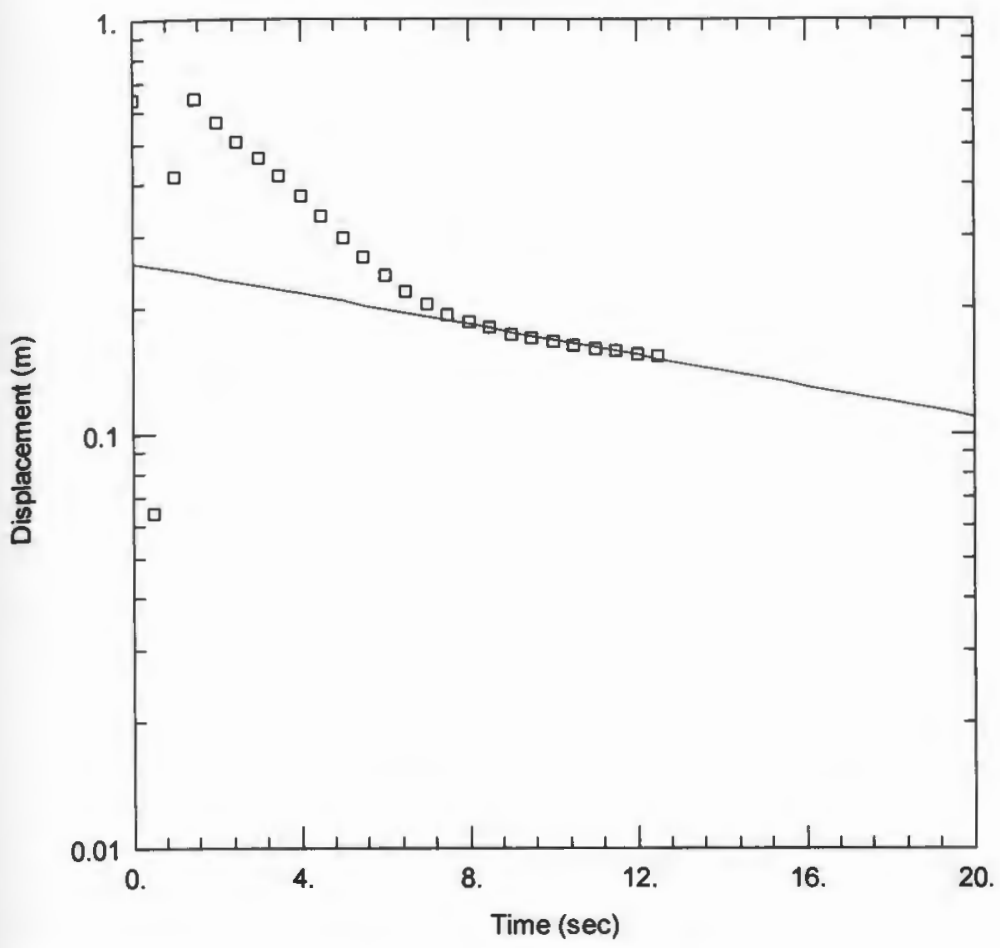

Obs. Wells $\square$ MW 56 Out

Aquifer Model Unconfined

Solution Bouwer-Rice

Parameters

$\mathrm{K}=0.0008262 \mathrm{~cm} / \mathrm{sec}$ yo $=0.2574 \mathrm{~m}$

Data Set: E:ITHESISPascoag_Files LStudy_SitelSlug Tests WW 56WW 56 Out.aqt

Date: $04 / 19 / 07$

Time: $11: 42: 34$

AQUIFER DATA

Saturated Thickness: $1.15 \mathrm{~m}$

Anisotropy Ratio (Kz/Kr): 1.

SLUG TEST WELL DATA

Initial Displacement: $0.639 \mathrm{~m}$

Casing Radius: $0.0127 \mathrm{~m}$

Wellbore Radius: $0.0381 \mathrm{~m}$

Well Skin Radius: $0.0381 \mathrm{~m}$

Screen Length: $0.9 \mathrm{~m}$

Total Well Penetration Depth: $0.94 \mathrm{~m}$

No. of observations: 25

Observation Date

Time (sec) Displacement (m) Time (sec) Displacement (m) Time (sec) Displacement (m)

$\begin{array}{ccccc}0.5 & 0.064 & 5 . & 0.297 \\ 1 . & 0.415 & 5.5 & 0.265 \\ 1.5 & 0.639 & 6 . & 0.24 \\ 2 . & 0.562 & 6.5 & 0.22 \\ 2.5 & 0.505 & 7 . & 0.205 \\ 3 . & 0.46 & 7.5 & 0.193 \\ 3.5 & 0.415 & 8 . & 0.185 \\ 4 . & 0.374 & 8.5 & 0.179 \\ 4.5 & 0.334 & 9 . & 0.173\end{array}$

SOLUTION

Aquifer Model: Unconfined

Solution Method: Bouwer-Rice

USUAL ESTIMATIONRESULTS

Estimated Parameters

Parameter Estimate

K $0.0008262 \mathrm{~cm} / \mathrm{sec}$

vo $0.2574 \mathrm{~m}$ 


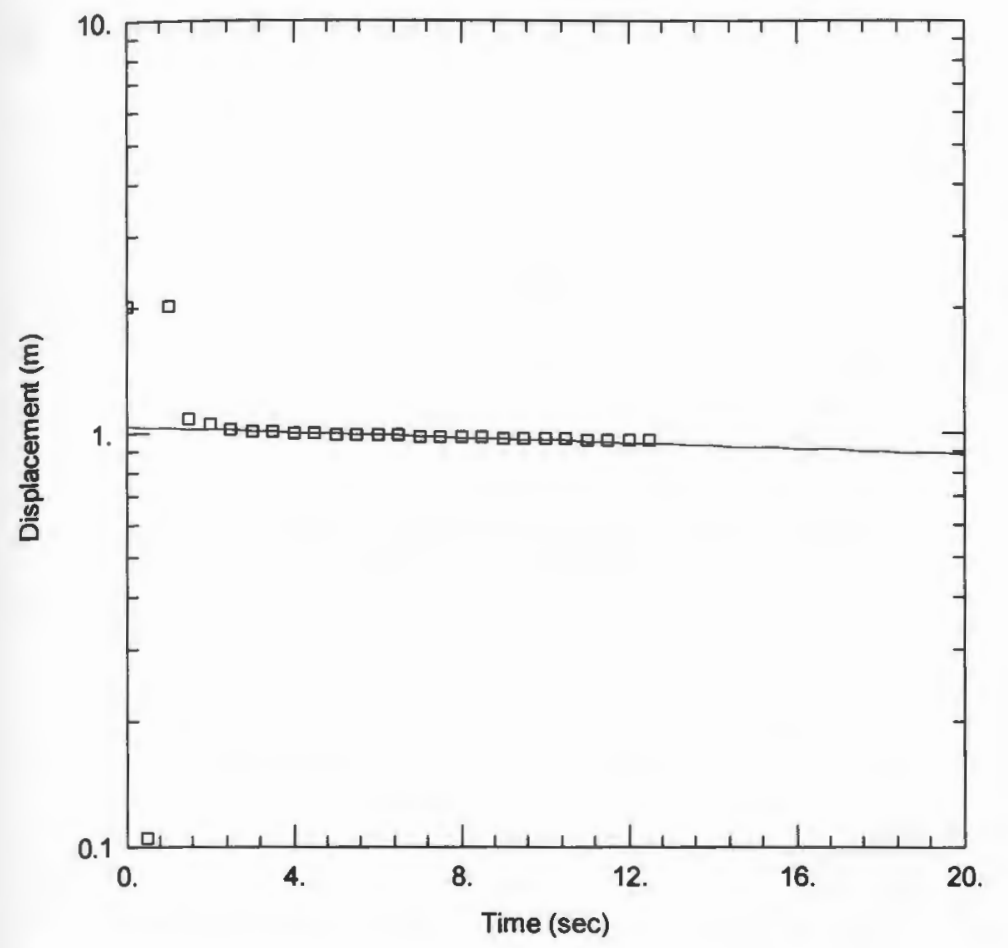

Obs. Wells

口 5D Out

Aquifer Model

Unconfined

Solution

Bouwer-Rice

Parameters

$\mathrm{K}=0.0005556 \mathrm{~cm} / \mathrm{sec}$

yo $=1.031 \mathrm{~m}$

Data Set: E:ITHESISIPascoeg_FilesIStudy_SitelSug Tests I5DI5D out.aqt

Date: $04 / 19 / 07$

Time: 11:44:33

\section{AQUIFER DATA}

Saturated Thickness: $1.8 \mathrm{~m}$

Anisotropy Ratio (Kz/Kr): 1.

SLUG TEST WELL DATA

Initial Displacement: $2.017 \mathrm{~m}$

Casing Radius: $0.0127 \mathrm{~m}$

Wellbore Radius: $0.0127 \mathrm{~m}$

Wen Skin Radius: $0.0127 \mathrm{~m}$

Screen Length: $0.3048 \mathrm{~m}$

Total Well Penetration Depth: $1.6 \mathrm{~m}$

No. of observations: 25

Observation Data

Time (sec) Displecement (m) Time (sec) Displacement (m) Time (sec) Displacement (m)

$0.5-0.105$

1. $\quad 2.017$

$1.5 \quad 1.08$

2. $\quad 1.049$

1.014

3. $\quad 1.007$

$3.5 \quad 1.001$

$\begin{array}{ll}4.5 & 0.997 \\ 4.5 & 0.993\end{array}$

$5 . \quad 0.989$

$\begin{array}{cc}5.5 & 0.986 \\ 6 . & 0.983\end{array}$

0.983
0.981

$\begin{array}{ll}7.5 & 0.978 \\ 7.5 & 0.976\end{array}$

$\begin{array}{ll}7.5 & 0.973\end{array}$

$\begin{array}{cc}8 . & 0.973 \\ 8.5 & 0.971\end{array}$

SOLUTION

0.969

$\begin{array}{cc}\text { Tine (sec) } & \text { Displacement (m) } \\ 9.5 & 0.967 \\ 10 . & 0.965 \\ 10.5 & 0.963 \\ 11 . & 0.96 \\ 11.5 & 0.959 \\ 12 . & 0.956 \\ 12.5 & 0.954\end{array}$

Aquifer Model: Unconfined

Solution Method: Boumer-Rice

VSUAL ESTIMATIONRESULTS

Estimated Parameters

$\begin{array}{ccc}\text { Parameter } & \begin{array}{c}\text { Estimate } \\ \mathrm{K}\end{array} & \begin{array}{c}0.0005556 \\ \mathrm{~cm} / \mathrm{sec}\end{array} \\ \text { yo } & 1.031 & \mathrm{~m}\end{array}$




\section{Hydraulic Gradient}

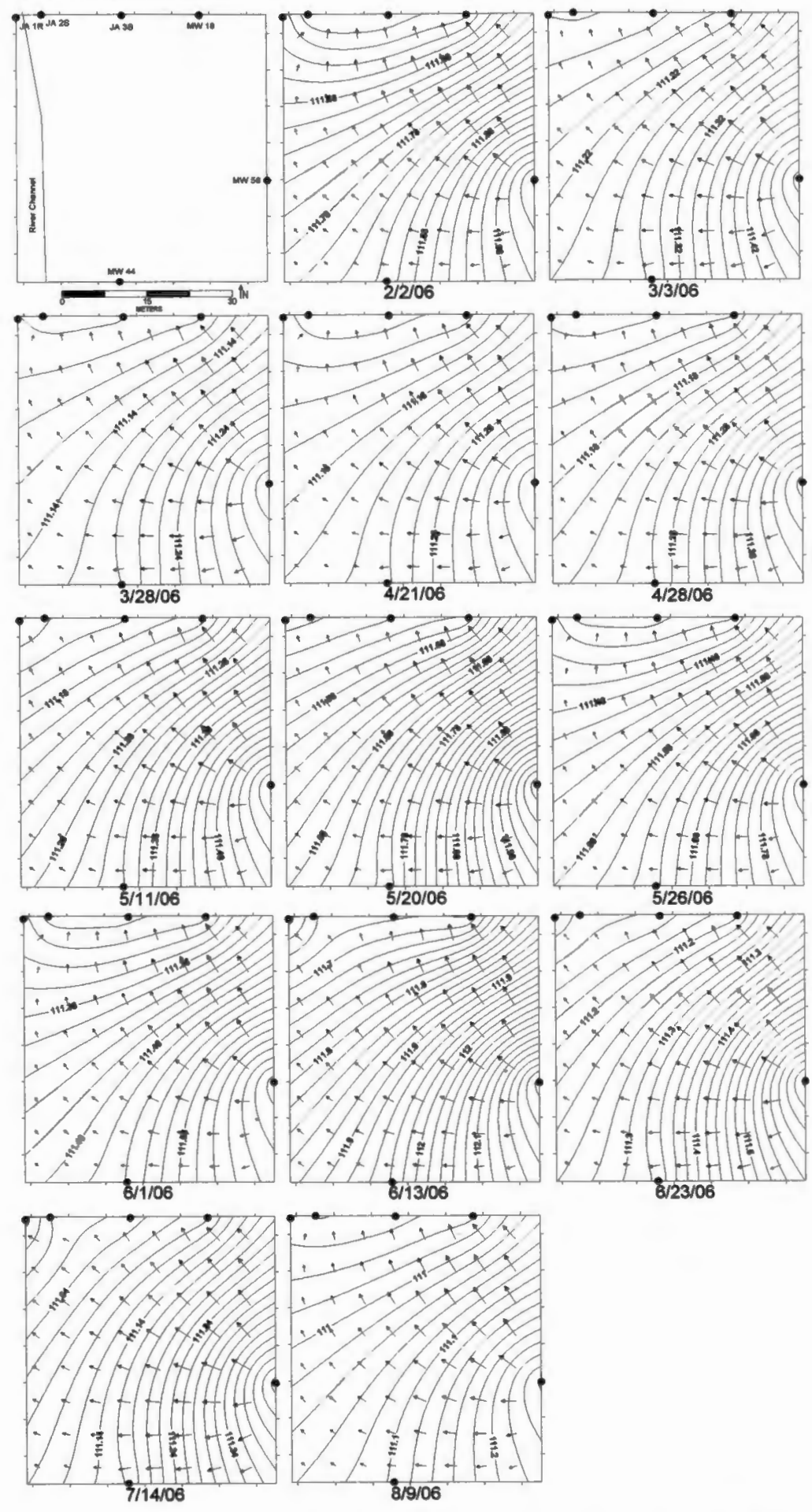

Figure 24. Supplemental floodplain ground-water flow regimes. 


\section{Hydraulic Gradient}

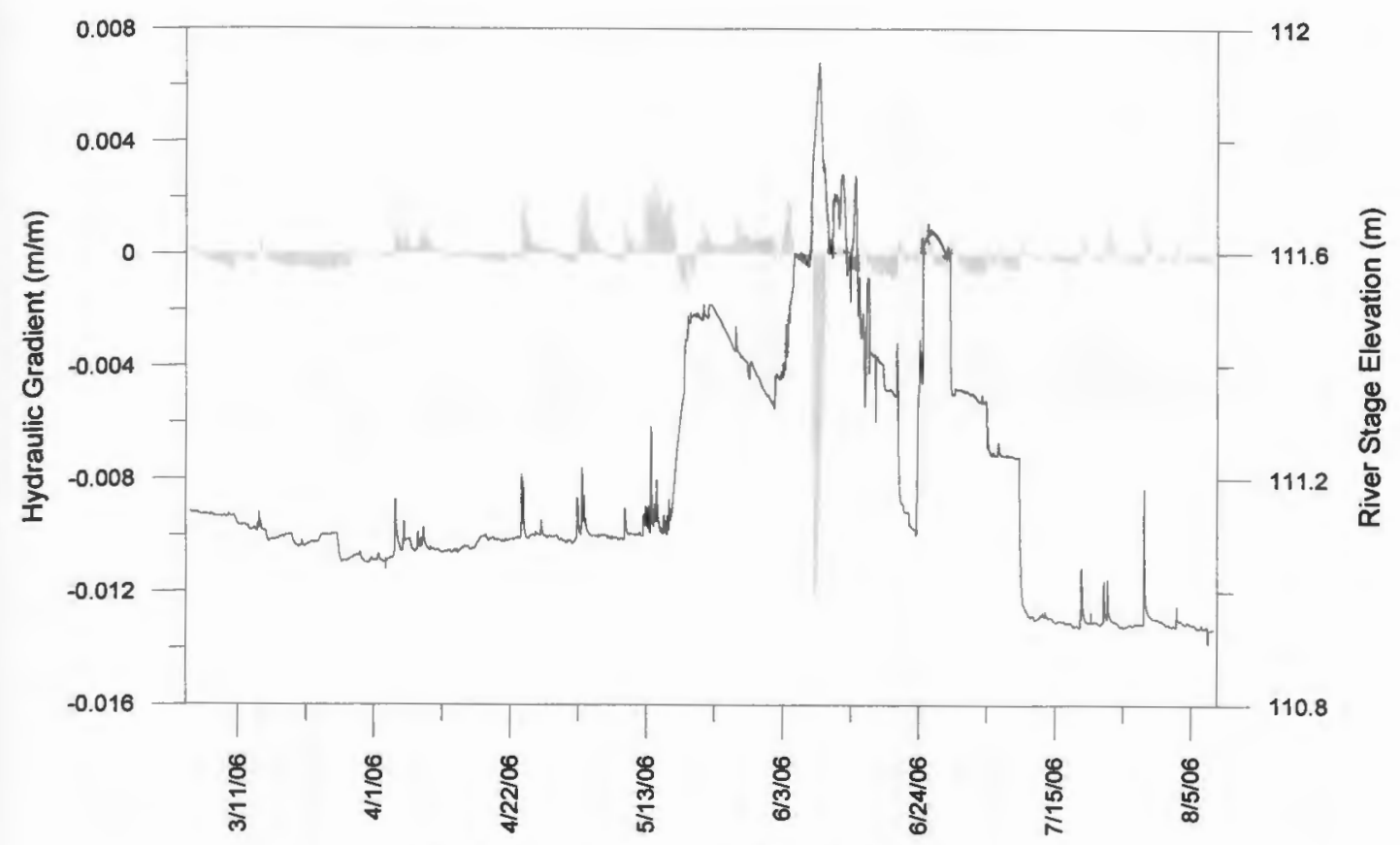

Figure 25. Hydraulic gradient from JA 3D to JA 2D. 


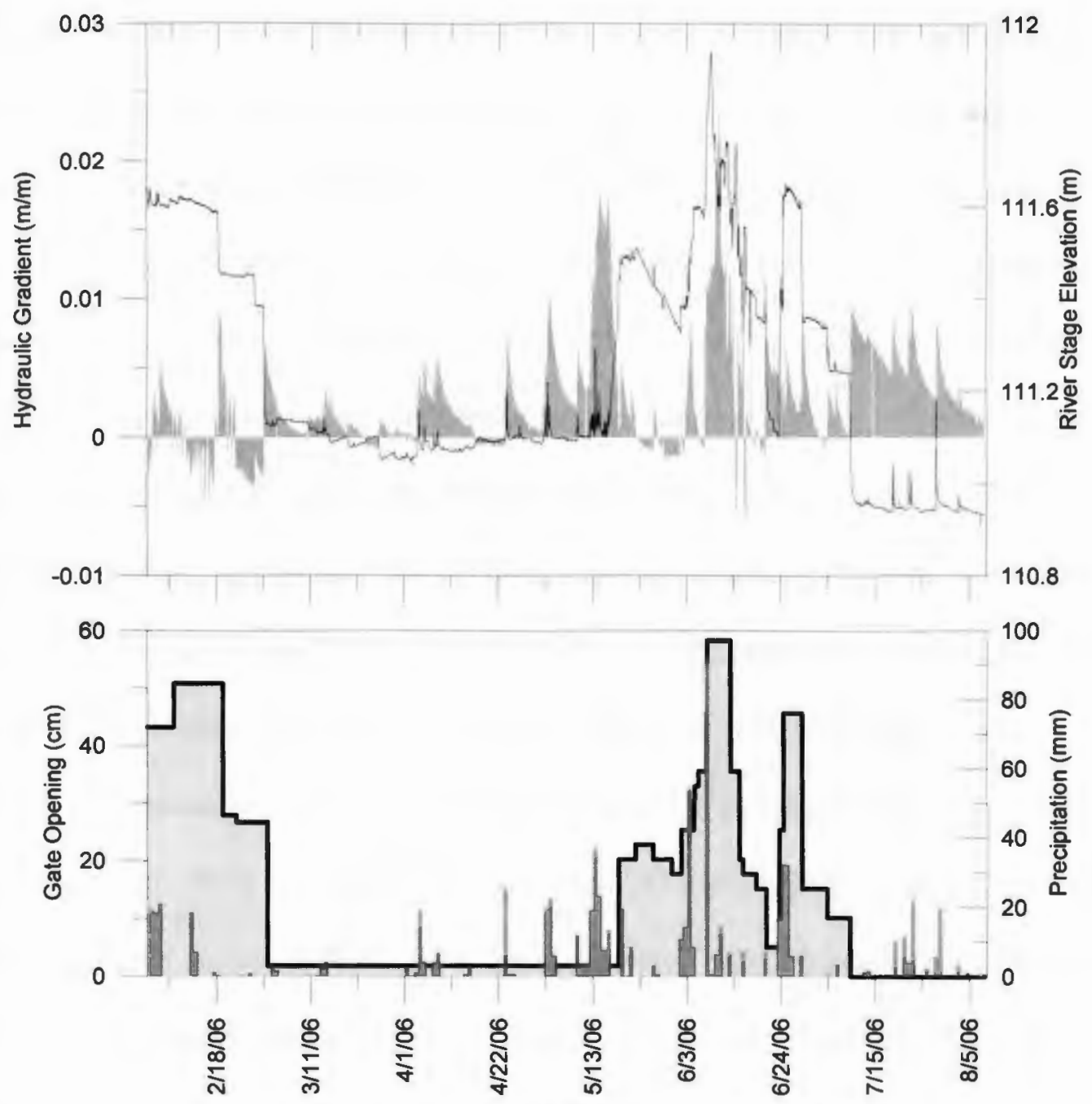

Figure 26. Hydraulic gradient between JA 3D and the river.

\section{Field Parameters}

Field parameters (electrical conductivity, dissolved oxygen, and $\mathrm{pH}$ ) can be a useful tool in determining shifting trends and changes in ground-water source or chemistry (Figure 27). Electrical conductivity (EC) is a measure of the amount of dissolved ions in solution. In general during this study, ion concentrations correlated well to EC. Please refer to the proceeding section for a complete description of ion concentrations. 
Dissolved oxygen (DO) is presented as the percent saturation because relative saturation concentration changes significantly with temperature. DO fluctuated primarily in response to precipitation but also in response to changes in the oxic state of the inflowing ground water. Most of the wells indicate that the ground water is typically anoxic with DO levels of less that $10 \%$. In the shallow wells (and wells with shallow screens), there was an increase as oxygen saturated precipitation infiltrated and mixed with shallow oxygen-depleted ground water. Periods with no rainfall coupled with biodegradation of contaminants and other natural DO removal resulted in depleted DO levels in the shallow ground water. DO fluctuations may indicate a shift in ground-water flow direction and source, and near the river indicate hyporheic exchange. Ground water in most wells was depleted in oxygen due to contaminant biodegradation. Well JA 2D had relatively high DO and suggests an oxic river water or ground-water source different from the other wells. MW 56 had high DO and EC levels which suggests that storm runoff may be a significant source for this shallow well.

DO levels in the riverbed wells provides insight into well depth relative to the hyporheic zone and indicates the depth of GW/SW exchange. Higher DO levels suggest that river water is present beneath the channel at the well screen, whereas a lower DO level indicates that ground water is discharging. In the river, lower DO levels show that ground water contributions have increased relative to surface water.

The $\mathrm{pH}$ results were limited in their use as an indicator of GW/SW interaction. Results from June 13 may be too low due to a loose wire on the $\mathrm{pH}$ meter. Overall, 
$\mathrm{pH}$ was relatively consistent at most locations and may have been most sensitive to rainfall resulting in a decrease in $\mathrm{pH}$.

\section{Ions}

Ion concentrations were related to dilution, concentration, DO abundance, and ground-water source (Figure 28). The conservative ions (sodium, potassium, magnesium, calcium, and chloride) behaved similarly at all wells except for slight differences between shallow and deep wells. In the shallow wells (and wells with shallow screens), there was a marked increase in concentrations during the dry period in March and April, presumably due to concentration of the shallow ground water. This continues until the onset of heavy precipitation which diluted the ground water and most ion concentrations decreased. There was then an increase in both the shallow and deep wells as the gradient steepened in mid-May. This may indicate a slight shift in the ground-water source and correlates with the increase in MTBE and BTEX concentrations. Typically high dissolved ion concentrations in MW 18 and $18 \mathrm{D}$, along with high MTBE and BTEX concentrations, suggests that the ground water in the contaminant plume is characterized by high dissolved ions. Therefore, increasing ion concentrations in a given well may indicate a shift of the hydraulic gradient and movement of the plume toward that well.

Nitrate and sulfate concentrations were mostly dependent on DO which controlled oxidation-reduction state (Hem 1985). Because the contaminant plume is typically anoxic, conditions are suitable for nitrate and sulfate reduction. This resulted in low concentrations during anoxic conditions in March and April and higher concentrations when dissolved oxygen was plentiful and reduction was prevented. This is especially 
important for sulfate which is present at relatively high concentrations upgradient near MW 56 but is reduced rapidly in the floodplain before reaching the river. Phosphate levels were generally low throughout the study due to removal through plant uptake (Hem 1985).

Riverbed and the river water samples also show trends in ion concentrations correlating well with hydraulic gradient steepening and increases in MTBE. In the river upstream of the study area, all ions decreased throughout the study period perhaps in response to dilution or decreasing contribution following winter road salt application. Regardless, the ion concentrations in the river at JA $1 \mathrm{R}$ responded independently of the upstream location. The river at the site responded with higher ion concentrations immediately following the gate closure in February, probably due to an increased proportion of ground-water from return-flow. During all other periods, no significant trends were observed.

\section{Water Temperature}

Water temperature data can be separated into several groups based upon general trends and relationships. Because of instrument difficulty, accidental removal, and a late monitoring start date in some wells there was some variability in the period of data collection (Table 8). The shallow wells JA 2S and JA 3S had larger temperature ranges, more extreme minimum and maximum temperatures, and a faster response than their corresponding deep wells (Figure 29). JA 2D and JA 3D both experienced their respective seasonal low temperatures in May and were otherwise smooth temperature curves. The iButton in JA 2D failed in June and was replaced with a less precise substitute resulting in less resolution throughout July. 
MW 18 and MW 18D temperature curves (Figure 29) were punctuated by many increases and decreases in temperature that appear to correspond to precipitation events or changes in river stage related to both precipitation events and reservoir gate adjustments. Like the shallow wells above, MW 18 had a steeper slope, and a larger temperature range, while MW 18D also had its seasonal low in May.

The four riverbed wells were monitored for various time periods but all show the same short-term and long-term trends (Figure 30). Specifically, temperatures remained low until the middle of May and then increased until stabilization June 1 through mid-June. Temperatures increased again and then rapidly decreased in early July when river stage declined before gradually increasing again in August. River temperature covaried with air temperature and appears to experience smaller diurnal variability when flow is greater, presumably in response to greater heat capacity (Constantz 1994). There were several periods when river temperature and air temperature trends diverged and may indicate a different water source and GW/SW exchange.

\section{Table 8 references}

Barlow et al. 2000; Becker et al. 2004; Burt et al. 2002; Burt et al. 2002; Castro and Hornberger 1991; Fryar et al. 2000; Girard et al. 2003; Hinzman et al. 2000; Hunt et al. 2006; Hussein and Schwartz 2003; Kasahara and Wondzell 2003; Kim and Hemond 1998; Lambs 2004; Lautz and Siegel 2006; Schilling et al. 2006; Schilling et al. 2006; Schubert 2002; Serrano and Workman 1998; Sheets et al. 2002; Triska et al. 1989; Vidon and Hill 2004; and Wroblicky et al. 1998. 


\section{APPENDIX IV: SUPPLEMENTARY GRAPHS}

Figure 27. Graphs of electrical conductivity (EC), dissolved oxygen (DO), and pH.
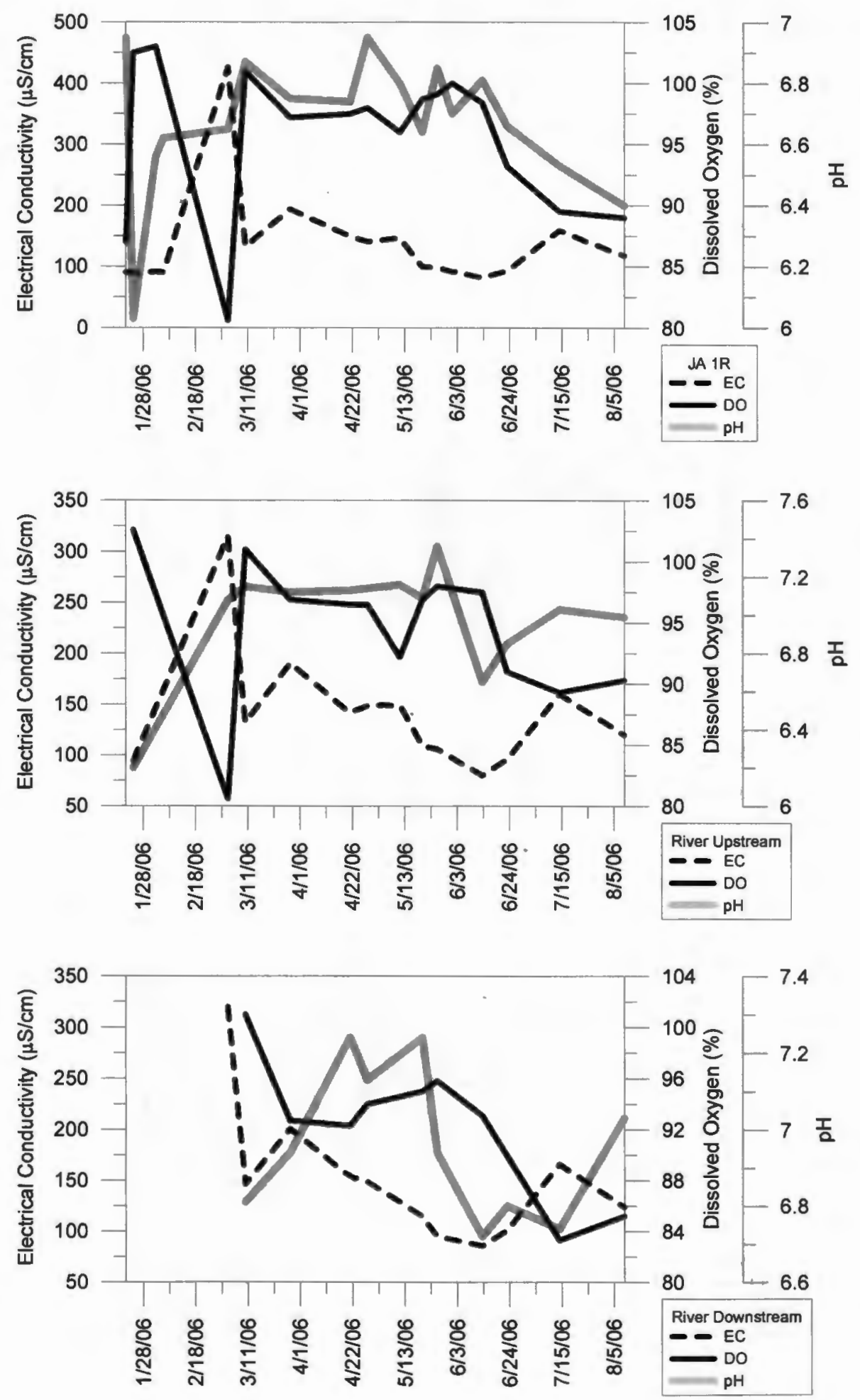
Electrical Conductivity $(\mu \mathrm{S} / \mathrm{cm})$

용

๖ำ

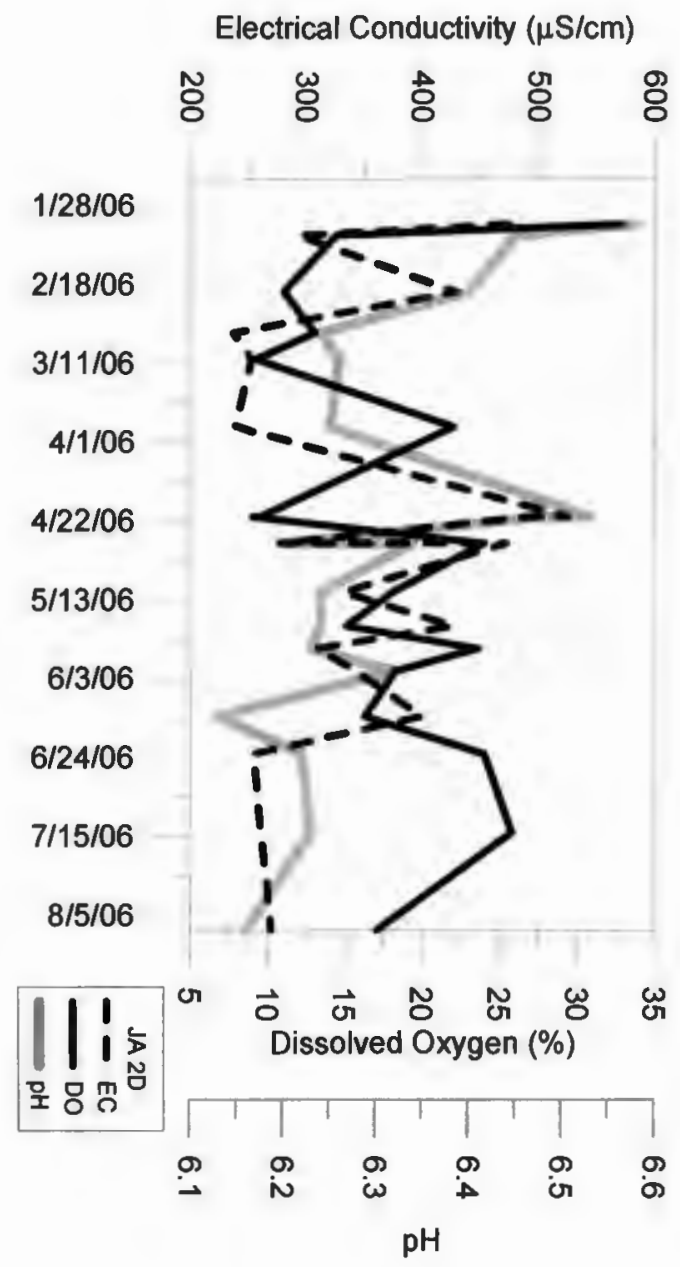

Electrical Conductivity $(\mu \mathrm{S} / \mathrm{cm})$

용 \&े

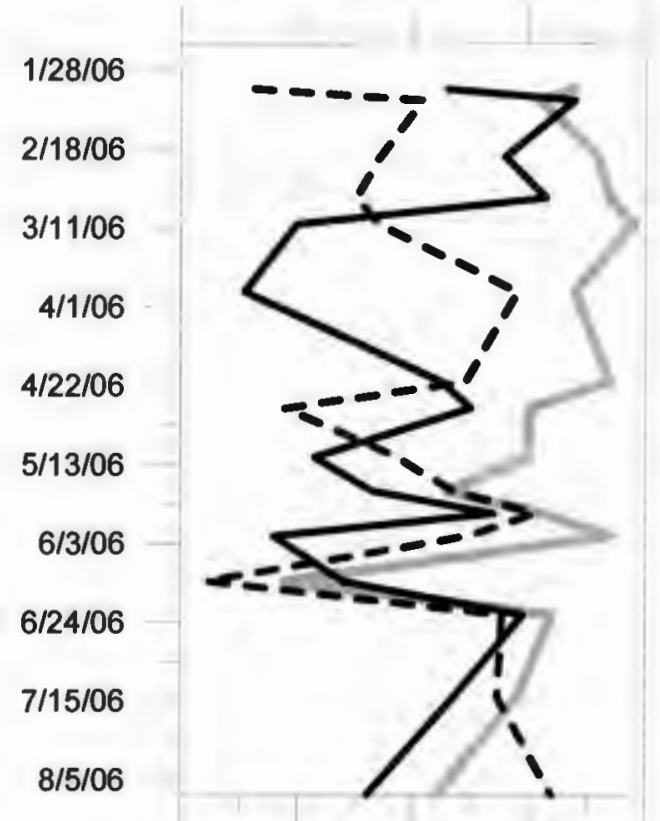

$11]^{N} \rightarrow \infty \quad \infty \quad \overrightarrow{0}$ 호 응 땡

Dissolved Oxygen (\%)

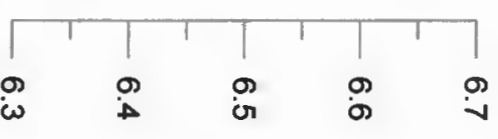

Electrical Conductivity $(\mu \mathrm{S} / \mathrm{cm})$

$\begin{array}{lll}\overrightarrow{0} & \overrightarrow{0} & \text { N }\end{array}$

$1 / 28 / 06$

2/18/06

$3 / 11 / 06$

4/1/06

4/22/06

$5 / 13 / 06$

$6 / 3 / 06$

$6 / 24 / 06$

7/15/06

$8 / 5 / 06$

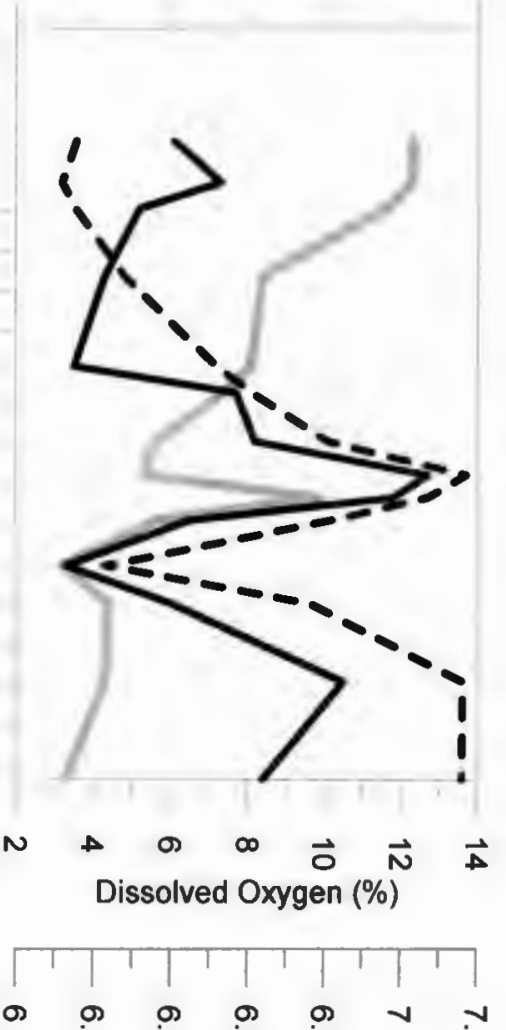

$|1|^{N} \rightarrow \infty \overrightarrow{0}^{N} \vec{A}$ Dissolved Oxygen (\%)

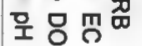

苂

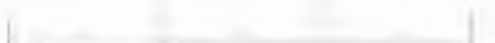


Electrical Conductivity $(\mu \mathrm{S} / \mathrm{cm})$

$\begin{array}{llll}8 & 0 & 0\end{array}$

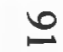

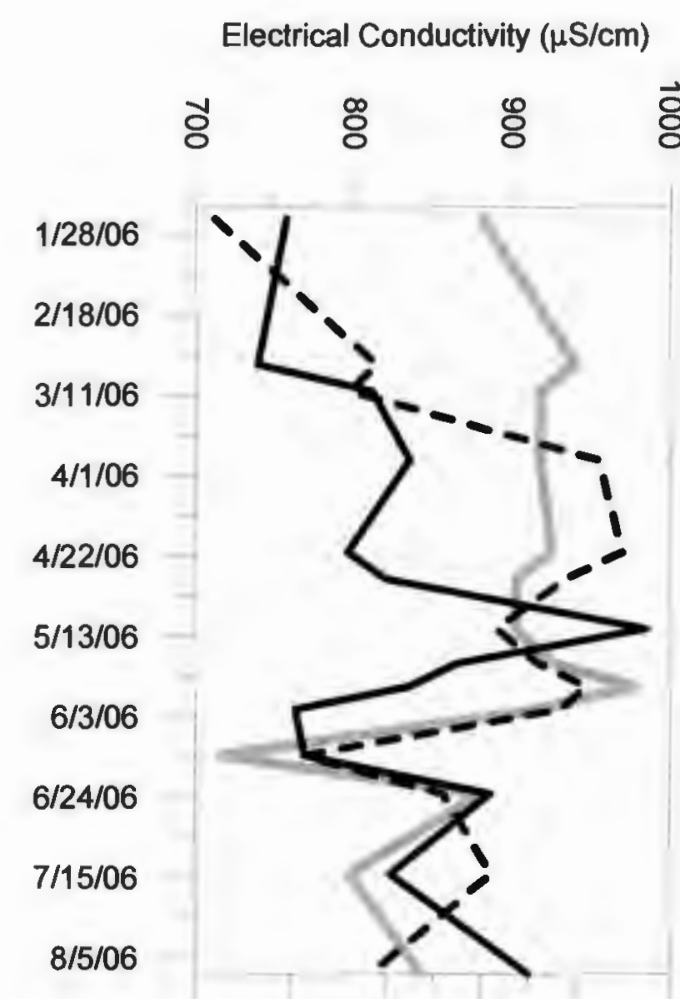

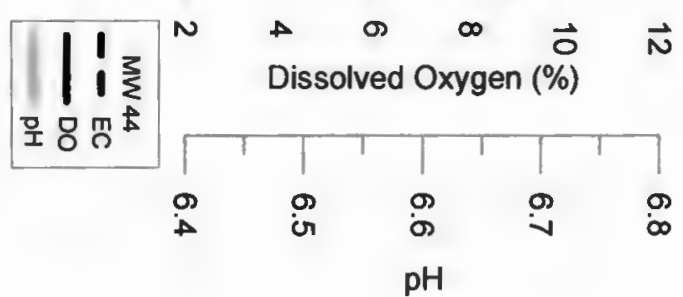

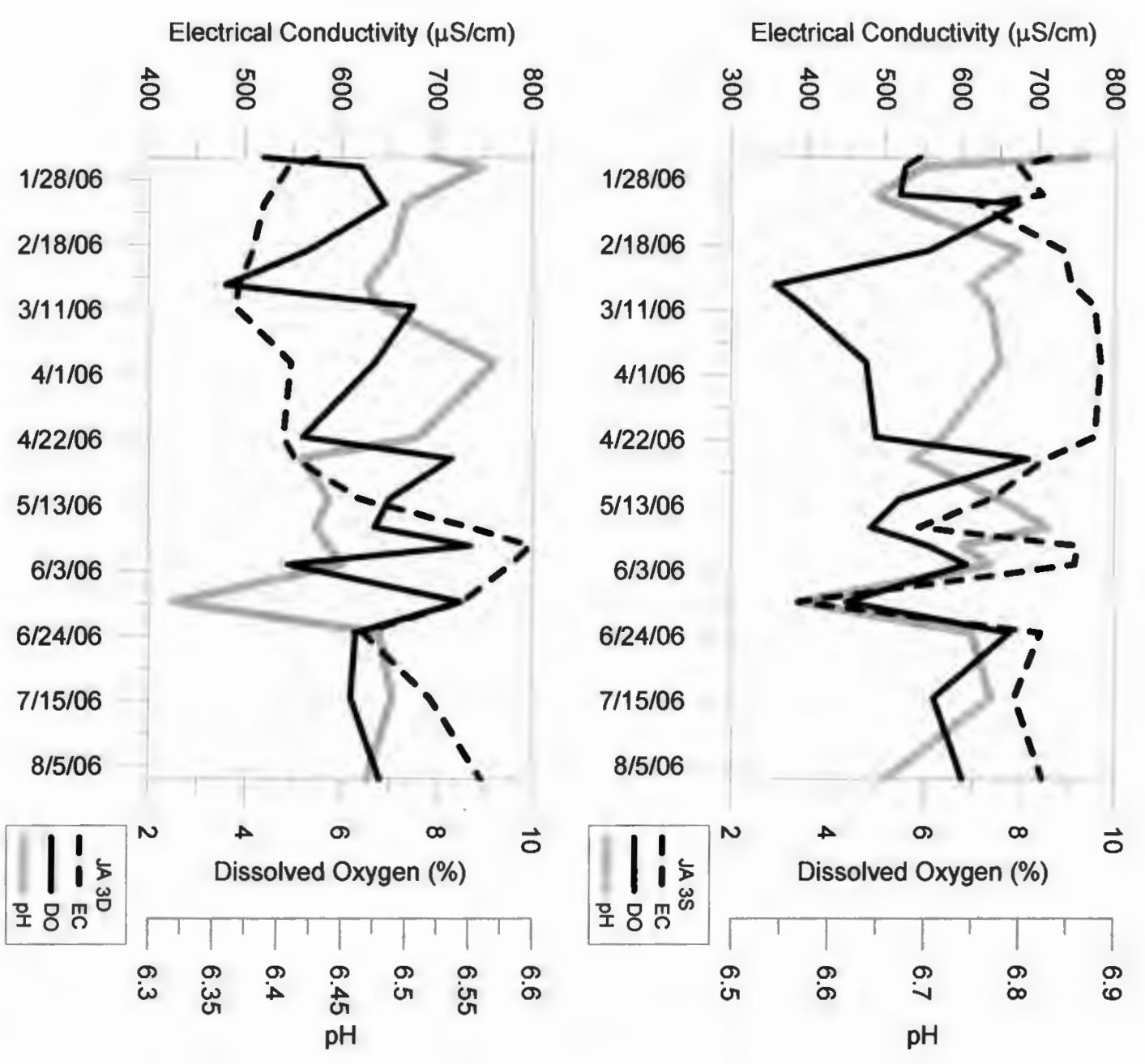


Electrical Conductivity $(\mu \mathrm{S} / \mathrm{cm})$

$\begin{array}{lllll} & 8 & \vec{N} & \overrightarrow{8} & \text { ㅇ }\end{array}$

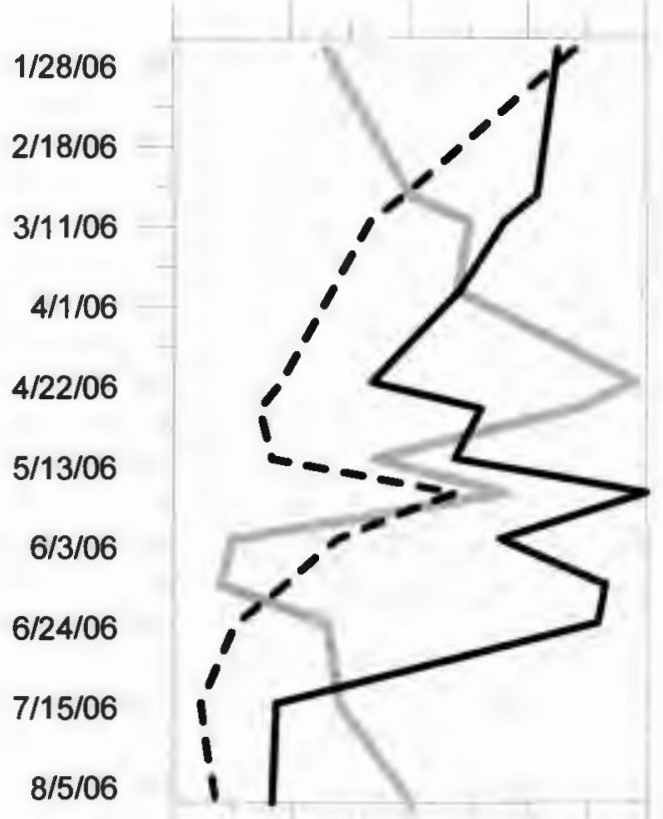

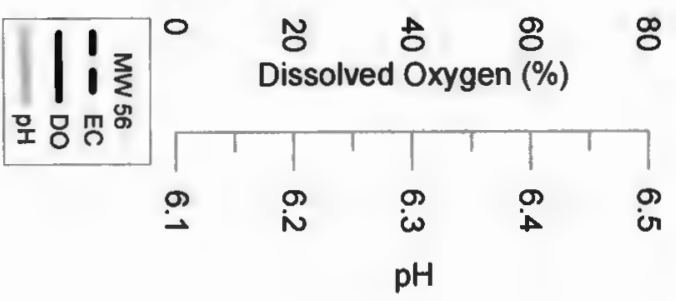

Electrical Conductivity $(\mu \mathrm{S} / \mathrm{cm})$

\begin{tabular}{lllll}
$\infty$ & $\infty$ & $\infty$ & $\mathscr{0}$ & $\mathscr{0}$ \\
\hdashline & $\stackrel{0}{0}$ & $\mathscr{0}$ & 0
\end{tabular}

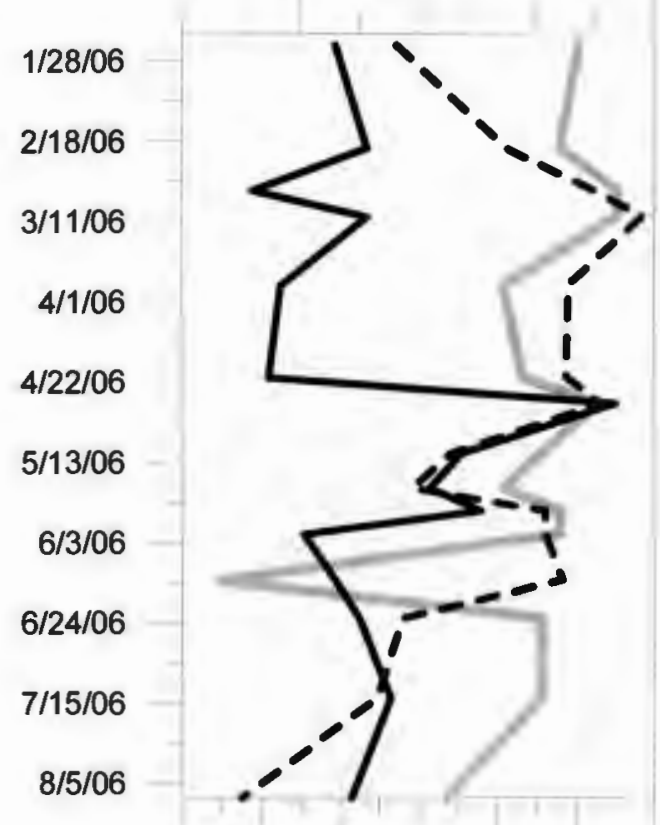

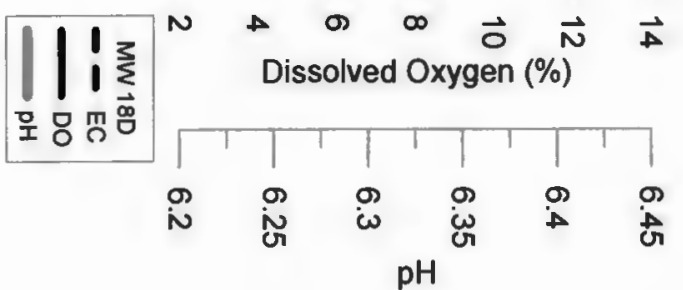

Electrical Conductivity $(\mu \mathrm{S} / \mathrm{cm})$

ڤั
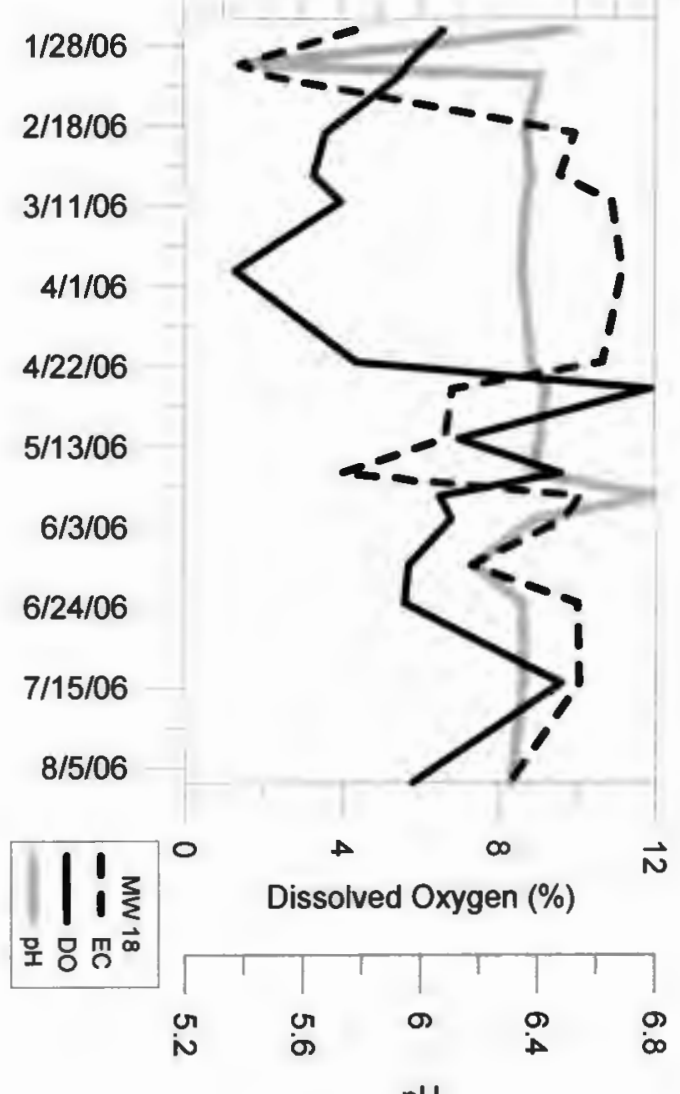
$\mathrm{pH}$ 
Electrical Conductivity ( $\mu S / \mathrm{cm})$

$\begin{array}{lllll}\vec{g} & \overrightarrow{0} & \stackrel{0}{0} & \text { N } & \text { 号 }\end{array}$

๘
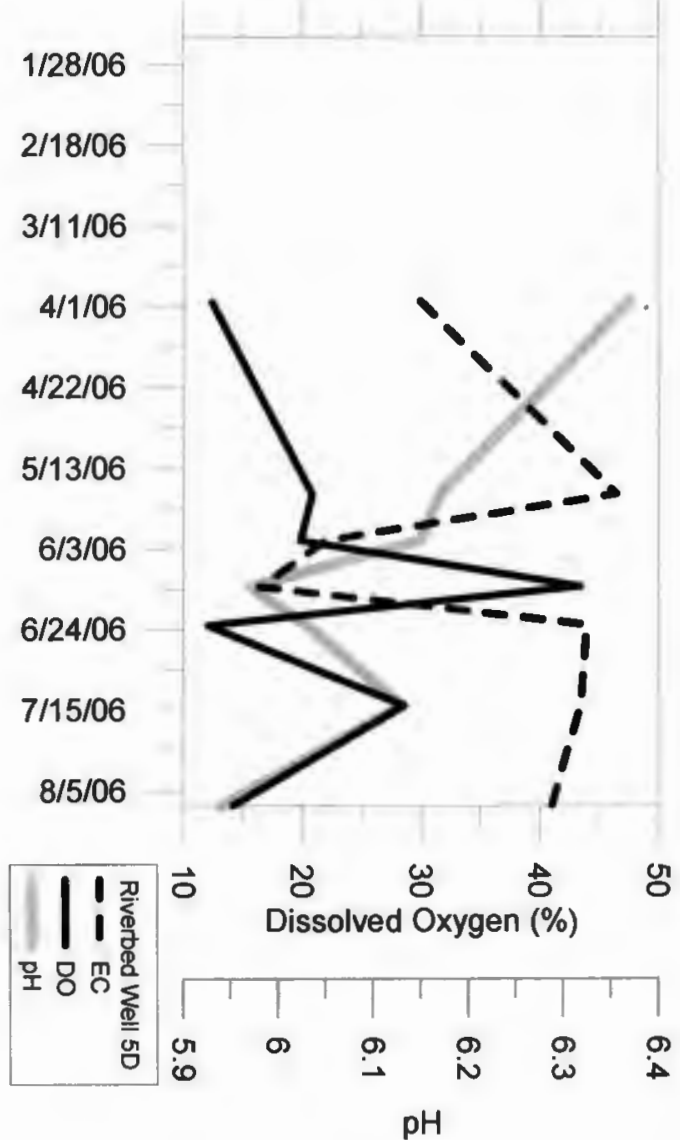

Electrical Conductivity $(\mu \mathrm{S} / \mathrm{cm})$

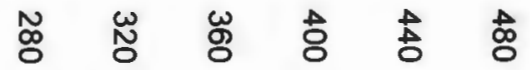

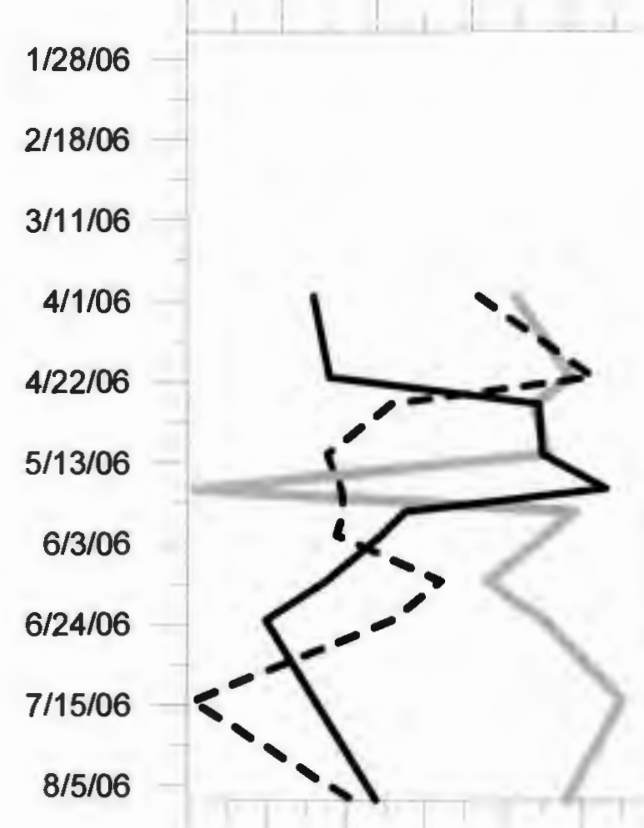

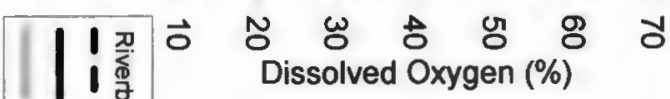
운 응 용 $\stackrel{\substack{\Phi \\ \hline}}{0}$

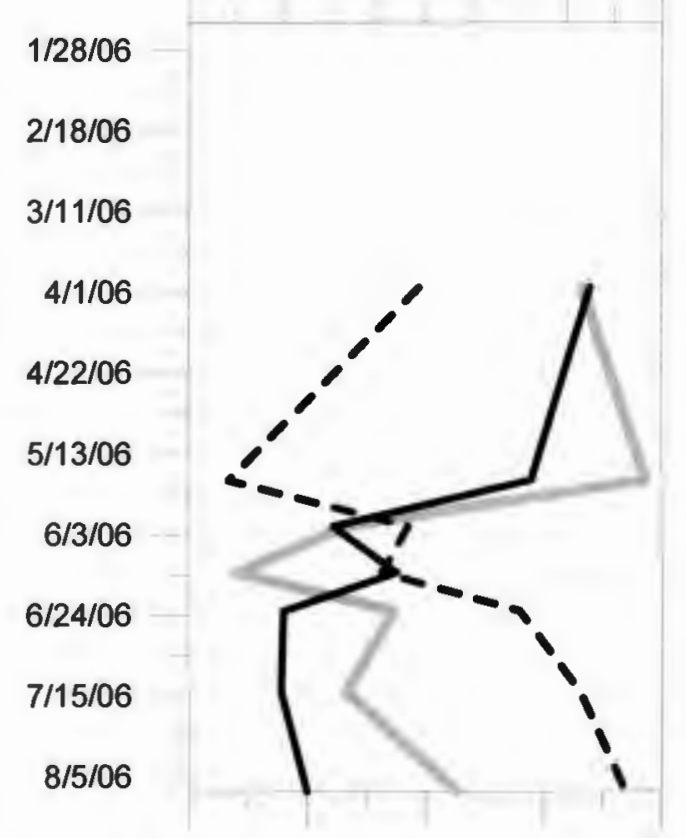

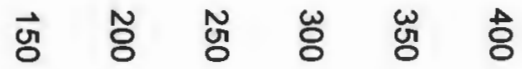

Electrical Conductivity ( $\mu \mathrm{S} / \mathrm{cm}$ )

s



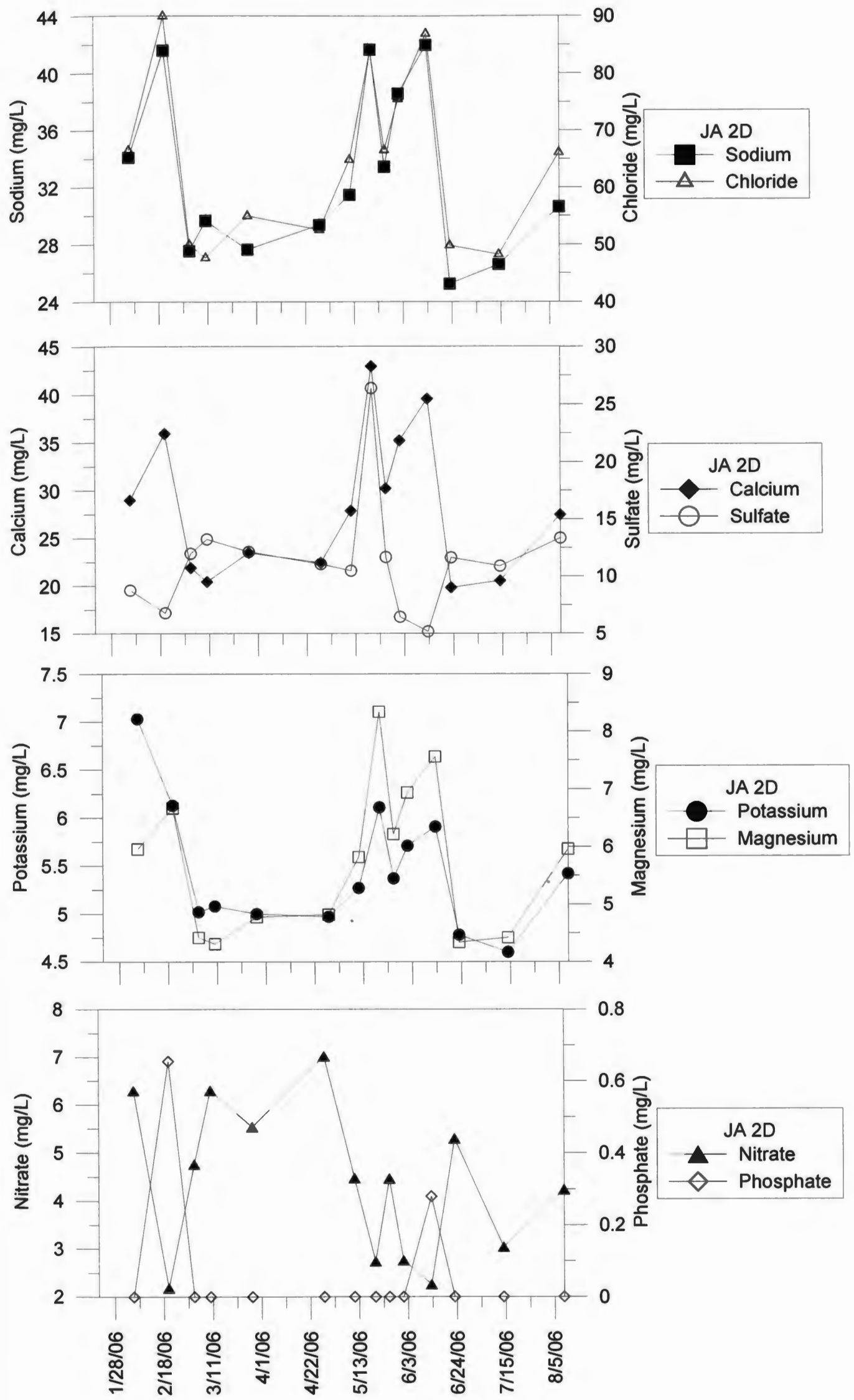

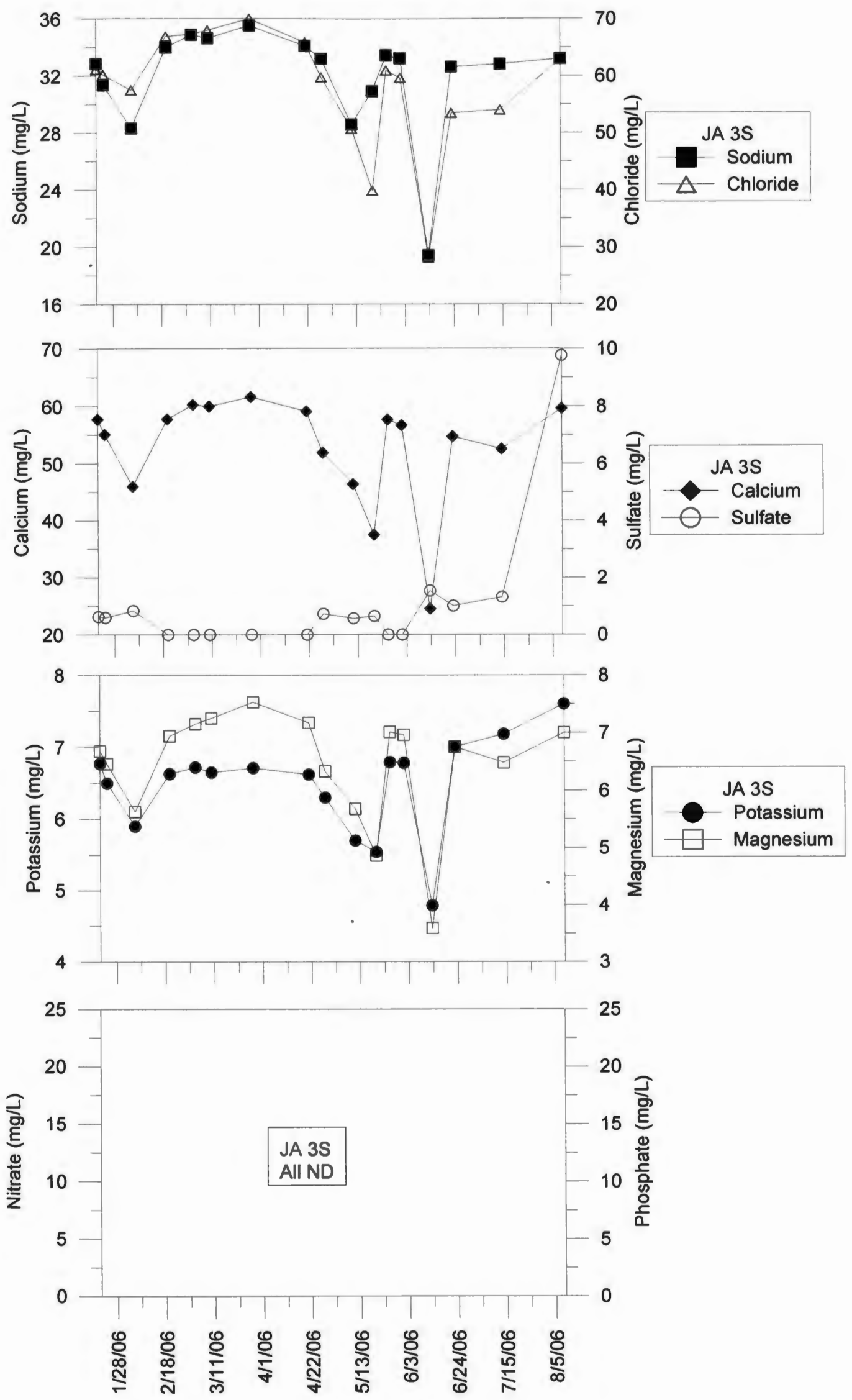

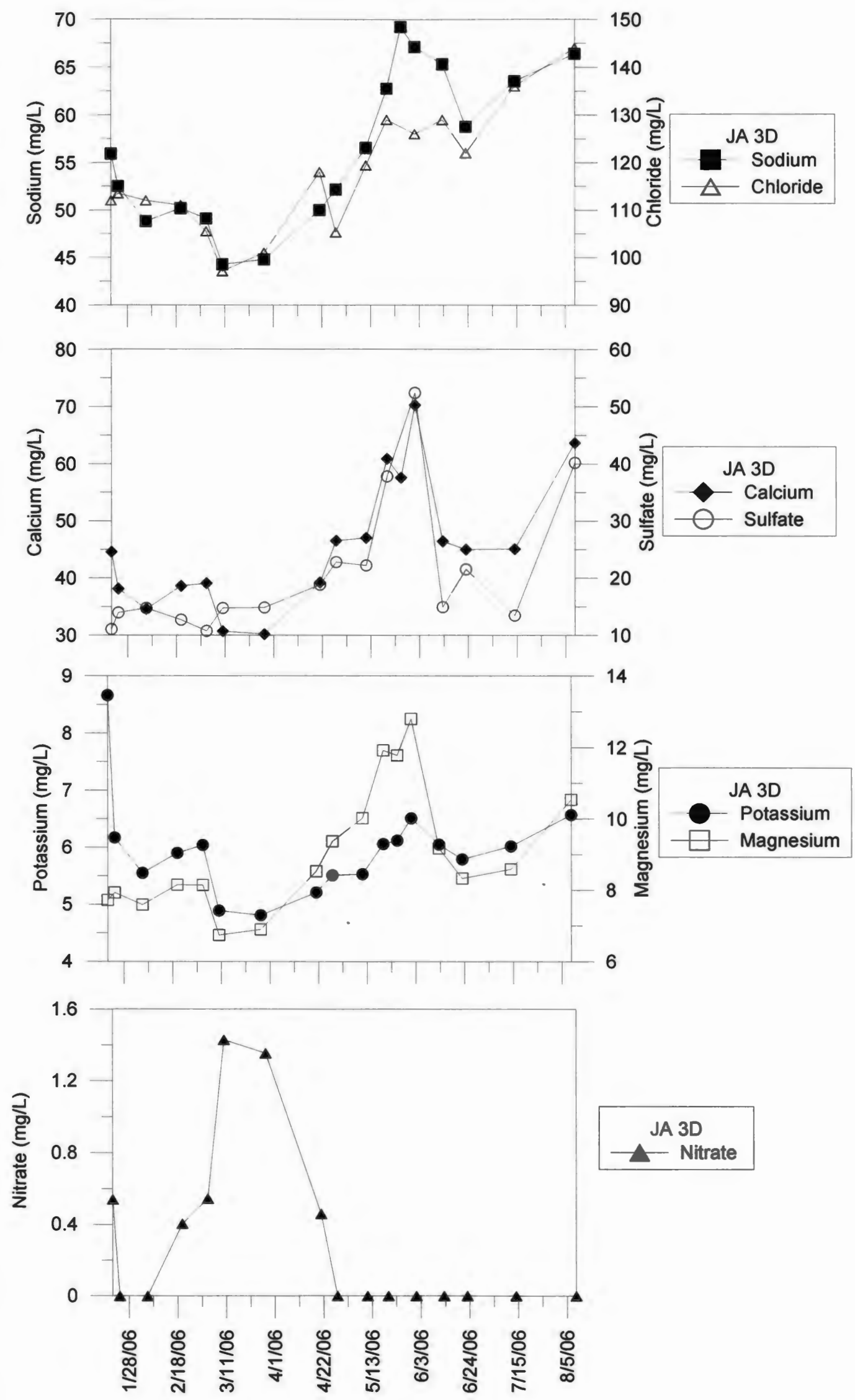

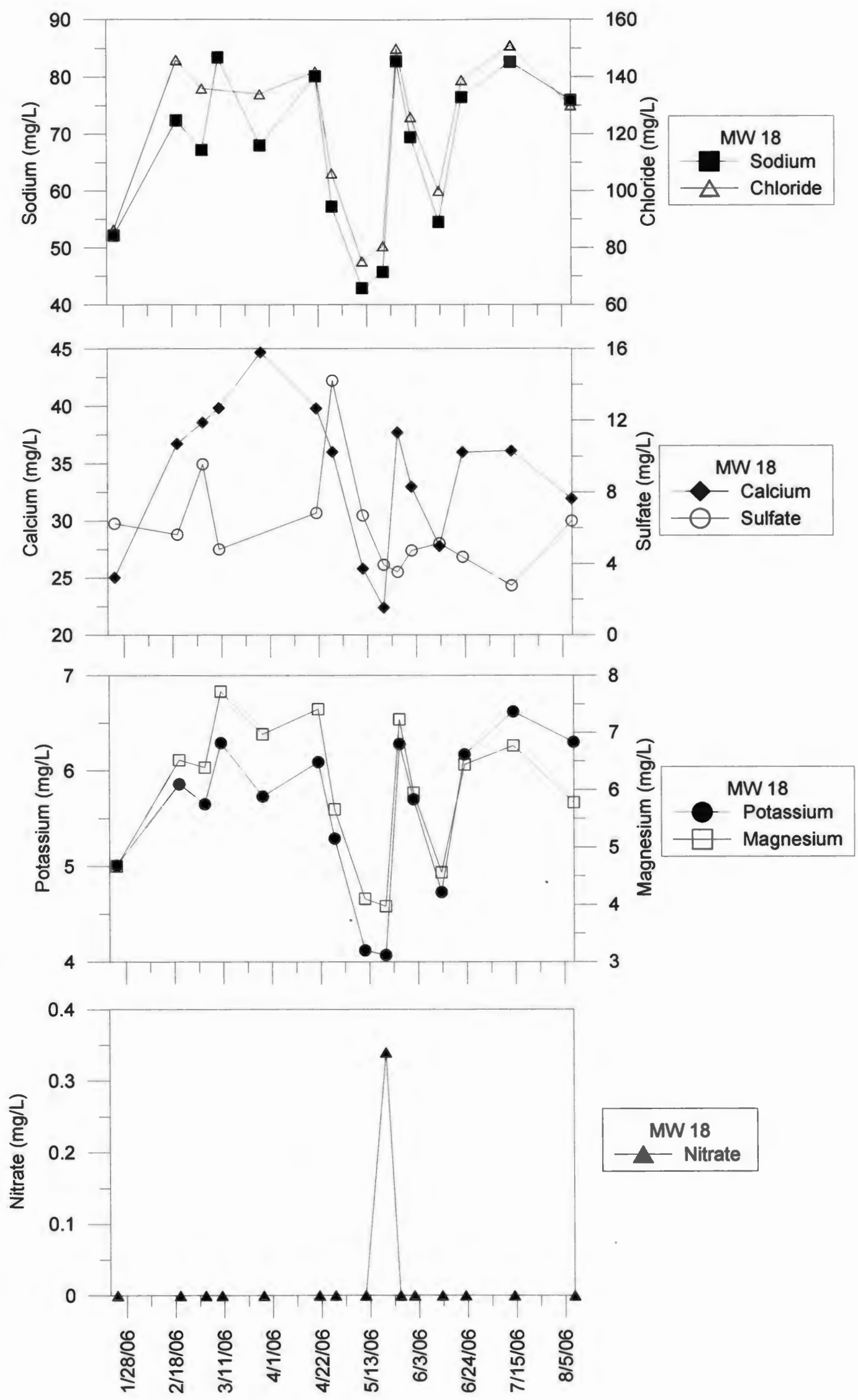

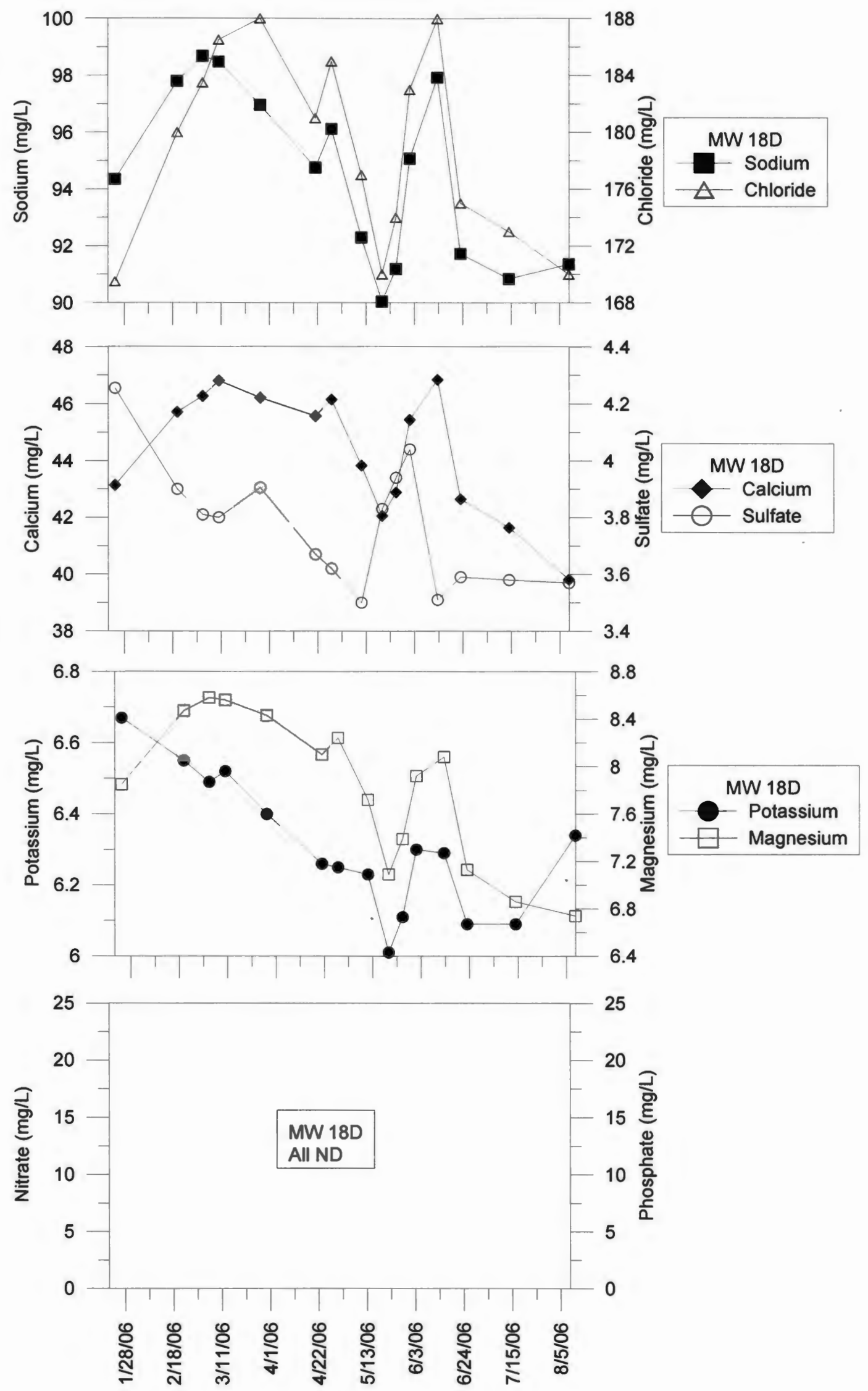

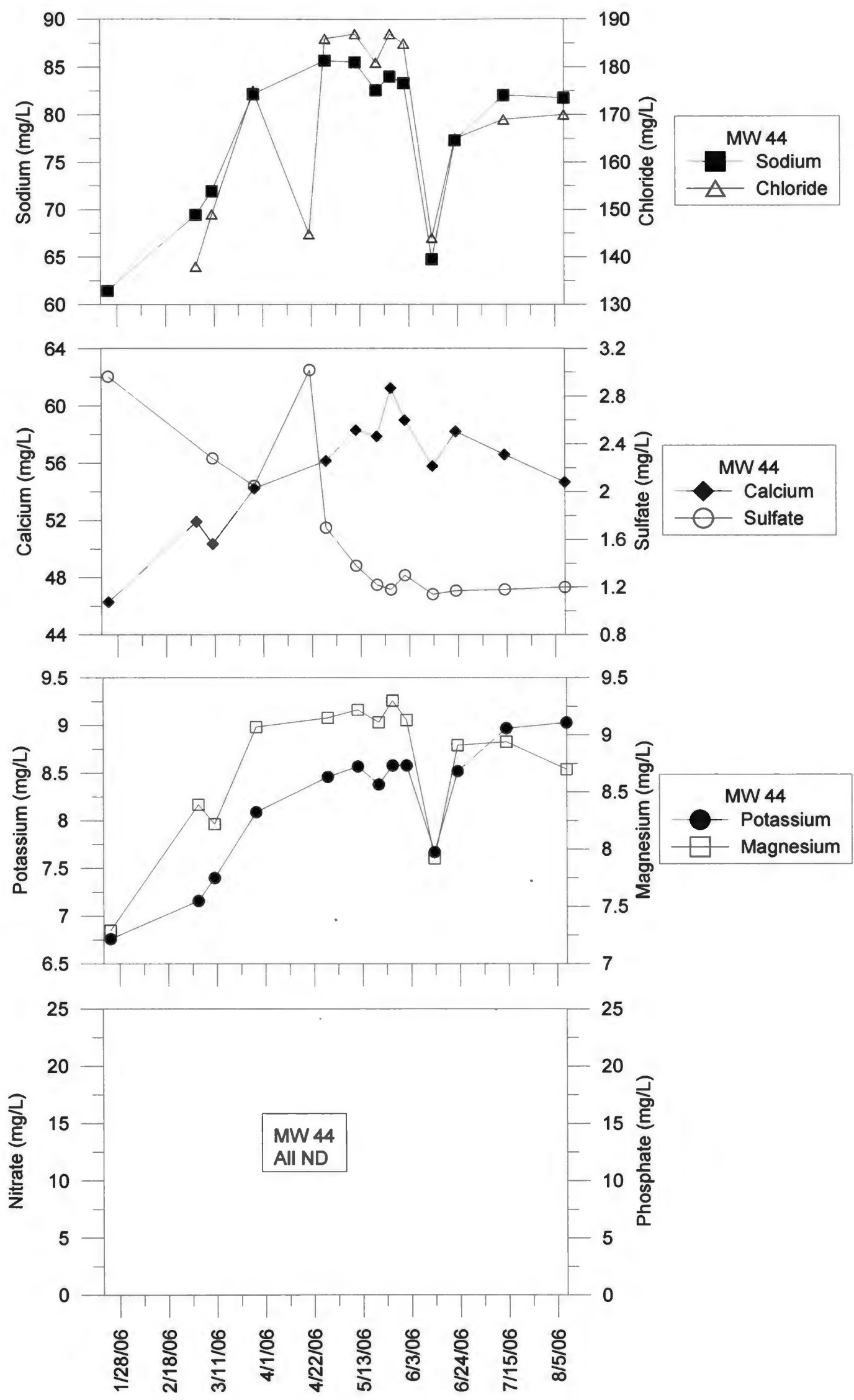

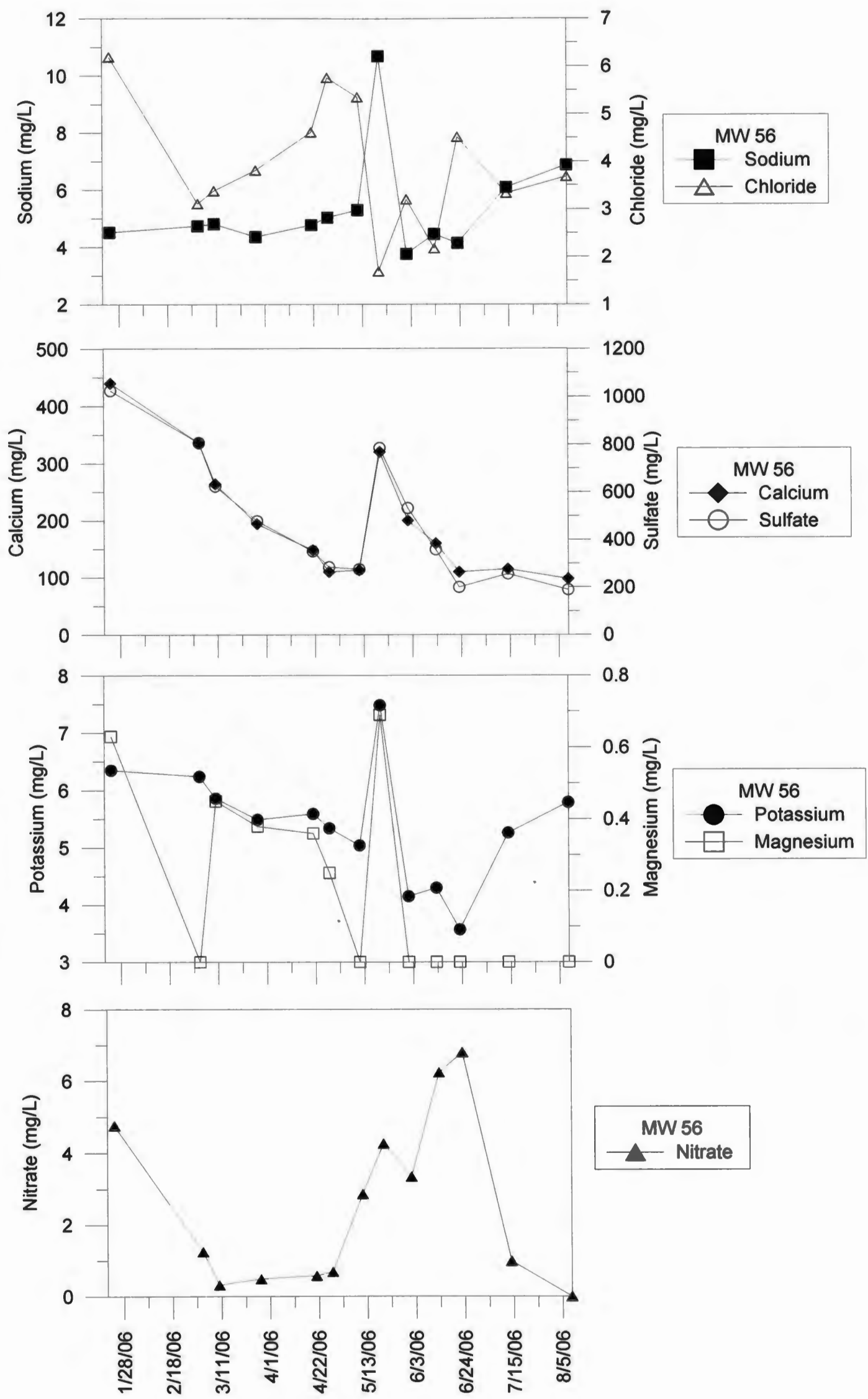
Figure 29. Graphs of floodplain well temperatures.

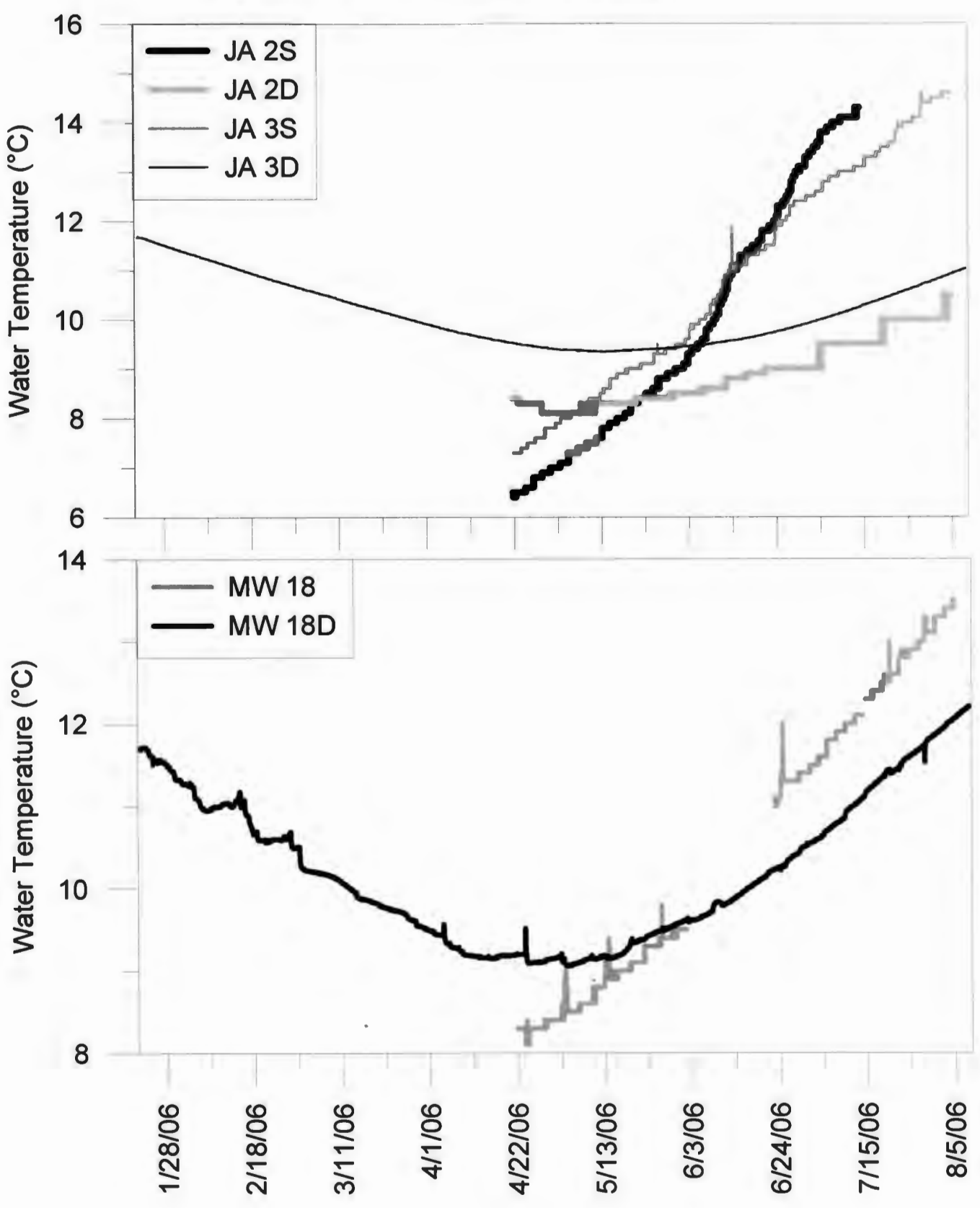




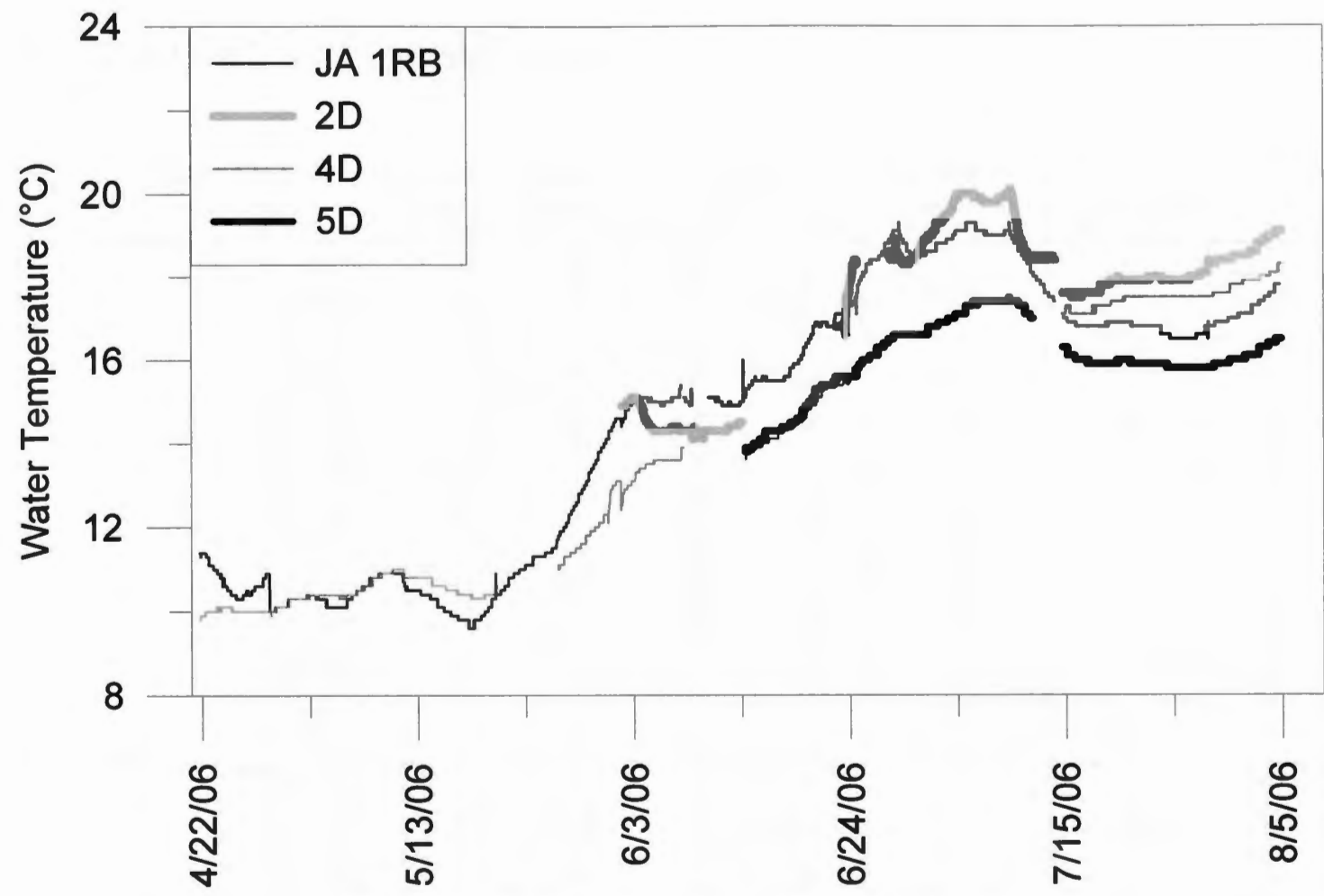

Figure 30. Graphs of riverbed well temperatures. 
APPENDIX V: SUPPLEMENTARY TABLES

Table 17. VOC individual results (Concentrations in $\mu \mathrm{g} / \mathrm{L}, \mathrm{ND}=$ Not detected).

\begin{tabular}{|c|c|c|c|c|c|c|c|c|}
\hline Well & Sample Date & Dilution & MTBE & Benzene & Toluene & Ethylbenzene & m-,p-xylene & o-xylene \\
\hline \multirow{16}{*}{ River at JA 1 R } & $1 / 21 / 2006$ & str & ND & ND & $\mathrm{ND}$ & $\mathrm{ND}$ & ND & ND \\
\hline & $2 / 20 / 2006$ & str & ND & ND & ND & ND & ND & $\mathrm{ND}$ \\
\hline & $3 / 3 / 2006$ & str & 1.0 & ND & ND & ND & ND & ND \\
\hline & $3 / 10 / 2006$ & str & 1.7 & ND & ND & ND & ND & ND \\
\hline & $3 / 28 / 2006$ & str & 1.4 & ND & ND & ND & ND & ND \\
\hline & $4 / 21 / 2006$ & str & ND & ND & ND & ND & ND & ND \\
\hline & $4 / 28 / 2006$ & str & ND & ND & ND & ND & ND & ND \\
\hline & $5 / 11 / 2006$ & str & 0.8 & ND & ND & ND & ND & ND \\
\hline & $5 / 18 / 2006$ & str & ND & ND & ND & ND & ND & ND \\
\hline & $5 / 20 / 2006$ & str & ND & ND & ND & ND & ND & ND \\
\hline & $5 / 26 / 2006$ & str & ND & ND & ND & ND & ND & ND \\
\hline & $6 / 13 / 2006$ & str & ND & ND & ND & ND & ND & ND \\
\hline & $6 / 22 / 2006$ & str & ND & ND & ND & ND & ND & ND \\
\hline & $6 / 23 / 2006$ & str & 0.7 & ND & ND & ND & ND & ND \\
\hline & $7 / 14 / 2006$ & str & 2.5 & $\mathrm{ND}$ & ND & ND & ND & ND \\
\hline & $8 / 9 / 2006$ & str & ND & $\mathrm{ND}$ & ND & ND & ND & ND \\
\hline \multirow{8}{*}{ River Upstream } & $3 / 3 / 2006$ & str & ND & ND & $\overline{\mathrm{ND}}$ & ND & ND & $\overline{\mathrm{ND}}$ \\
\hline & $3 / 28 / 2006$ & str & ND & ND & ND & ND & ND & ND \\
\hline & $4 / 21 / 2006$ & str & ND & ND & ND & ND & ND & ND \\
\hline & $5 / 20 / 2006$ & str & ND & ND & ND & ND & ND & ND \\
\hline & $6 / 13 / 2006$ & str & ND & ND & ND & ND & ND & ND \\
\hline & $6 / 23 / 2006$ & str & ND & ND & ND & ND & ND & ND \\
\hline & $7 / 14 / 2006$ & str & ND & ND & ND & ND & ND & ND \\
\hline & $8 / 9 / 2006$ & str & ND & ND & ND & ND & ND & ND \\
\hline \multirow{12}{*}{$\begin{array}{c}\text { River } \\
\text { Downstream }\end{array}$} & $3 / 3 / 2006$ & str & 32.2 & 1.9 & 1.2 & 2.0 & 1.9 & 1.7 \\
\hline & $3 / 10 / 2006$ & str & 14.2 & 2.7 & ND & ND & 3.4 & ND \\
\hline & $3 / 28 / 2006$ & str & 26.5 & 2.7 & 1.5 & 2.5 & 2.1 & 2.0 \\
\hline & $4 / 21 / 2006$ & str & 7.5 & 1.4 & 1.9 & 1.7 & 1.5 & ND \\
\hline & $4 / 28 / 2006$ & str & 11.7 & 2.1 & 2.2 & 2.1 & 1.8 & 1.9 \\
\hline & $5 / 20 / 2006$ & str & 7.9 & 1.6 & ND & ND & ND & ND \\
\hline & $5 / 26 / 2006$ & str & 0.9 & ND & ND & ND & ND & ND \\
\hline & $6 / 13 / 2006$ & str & 2.1 & ND & ND & ND & ND & ND \\
\hline & $6 / 22 / 2006$ & str & 14.9 & 2.2 & ND & ND & ND & ND \\
\hline & $6 / 23 / 2006$ & str & 11.8 & 2.2 & ND & 2.1 & ND & ND \\
\hline & $7 / 14 / 2006$ & str & 12.8 & 3.4 & 3.2 & 4.0 & 3.9 & 2.4 \\
\hline & $8 / 9 / 2006$ & str & 1.0 & 0.8 & $\mathrm{ND}$ & ND & ND & ND \\
\hline \multirow{14}{*}{ JA 1RB } & $2 / 20 / 2006$ & str & 21.7 & 1.3 & $\mathrm{ND}$ & $\mathrm{ND}$ & ND & ND \\
\hline & $3 / 3 / 2006$ & str & 13.9 & 0.3 & ND & ND & ND & ND \\
\hline & $3 / 10 / 2006$ & str & 18.6 & ND & ND & ND & ND & ND \\
\hline & $3 / 28 / 2006$ & str & 30.6 & ND & ND & ND & ND & ND \\
\hline & $4 / 21 / 2006$ & str & 28.4 & ND & ND & ND & ND & ND \\
\hline & $4 / 28 / 2006$ & str & 27.6 & ND & ND & ND & ND & ND \\
\hline & $5 / 11 / 2006$ & str & 16.0 & ND & ND & ND & ND & ND \\
\hline & $5 / 20 / 2006$ & str & 150 & 2.2 & ND & ND & ND & ND \\
\hline & $5 / 26 / 2006$ & str & 179 & 1.6 & ND & ND & ND & ND \\
\hline & $6 / 1 / 2006$ & str & 134 & 1.3 & ND & ND & ND & ND \\
\hline & $6 / 13 / 2006$ & str & 22.7 & ND & ND & ND & ND & ND \\
\hline & $6 / 23 / 2006$ & str & 19.8 & ND & ND & ND & ND & ND \\
\hline & $7 / 14 / 2006$ & str & 9.6 & ND & ND & ND & ND & ND \\
\hline & $8 / 9 / 2006$ & str & 65.0 & ND & ND & ND & ND & ND \\
\hline
\end{tabular}




\begin{tabular}{|c|c|c|c|c|c|c|c|c|}
\hline Well & Sample Date & Dilution & $\overline{\mathrm{MTBE}}$ & Benzene & Toluene & Ethylbenzene & m-,p-xylene & o-xylene \\
\hline \multirow{14}{*}{ MW 44} & $1 / 24 / 2006$ & str, 1:50 & 1970 & 25.1 & 15.2 & 60.9 & 13.3 & 20.3 \\
\hline & $3 / 3 / 2006$ & str, $1: 25$ & 2030 & 34.0 & 2.9 & 55.2 & 2.5 & 3.9 \\
\hline & $3 / 10 / 2006$ & str, $1: 20$ & 1808 & 35.0 & 5.1 & 55.9 & 4.2 & 6.2 \\
\hline & $3 / 28 / 2006$ & $1: 25,1: 5$ & 2310 & 26.5 & ND & 52.3 & $\mathrm{ND}$ & ND \\
\hline & $4 / 21 / 2006$ & $1: 20,1: 5$ & 2263 & 33.4 & ND & 43.8 & ND & ND \\
\hline & $4 / 28 / 2006$ & $1: 20,1: 5$ & 2155 & 31.7 & ND & 38.5 & ND & ND \\
\hline & $5 / 11 / 2006$ & $1: 20,1: 5$ & 1949 & 30.5 & 9.6 & 32.1 & ND & ND \\
\hline & $5 / 20 / 2006$ & 1:20, & 1820 & NA & NA & NA & NA & NA \\
\hline & $5 / 26 / 2006$ & $1: 20,1: 5$ & 1668 & 25.0 & 14.6 & 40.5 & 19.4 & ND \\
\hline & $6 / 1 / 2006$ & $1: 20,1: 5$ & 1646 & 21.2 & 12.9 & 33.0 & ND & ND \\
\hline & $6 / 13 / 2006$ & $1: 20,1: 2$ & 889 & 8.9 & ND & 5.1 & 4.5 & ND \\
\hline & $6 / 23 / 2006$ & $1: 20,1: 4$ & 1409 & 15.8 & 10.8 & 14.1 & 10.1 & ND \\
\hline & $7 / 14 / 2006$ & $1: 20,1: 4$ & 1454 & 18.9 & 13.2 & 23.8 & 17.4 & ND \\
\hline & $8 / 9 / 2006$ & $1: 20,1: 4$ & 1387 & 12.3 & ND & ND & ND & ND \\
\hline \multirow{12}{*}{ MW 56} & $3 / 3 / 2006$ & str & 1.6 & ND & ND & 1.4 & ND & ND \\
\hline & $3 / 10 / 2006$ & str & 4.2 & 1.7 & 2.1 & 2.7 & 2.6 & ND \\
\hline & $3 / 28 / 2006$ & str & 2.0 & ND & 0.0 & 2.3 & 0.5 & ND \\
\hline & $4 / 21 / 2006$ & str & 9.0 & 2.6 & ND & 11.8 & 3.3 & 2.2 \\
\hline & $4 / 28 / 2006$ & str & 11.9 & 3.9 & 2.9 & 28.5 & 8.4 & 2.7 \\
\hline & $5 / 11 / 2006$ & str & 4.4 & 2.7 & 2.1 & 20.0 & 7.1 & 2.2 \\
\hline & $5 / 20 / 2006$ & str & ND & ND & ND & 2.5 & ND & ND \\
\hline & $6 / 1 / 2006$ & str & ND & 1.6 & ND & 4.0 & ND & ND \\
\hline & $6 / 13 / 2006$ & str & ND & ND & ND & ND & ND & ND \\
\hline & $6 / 23 / 2006$ & str & ND & $\mathrm{ND}$ & ND & ND & ND & ND \\
\hline & $7 / 14 / 2006$ & str & 2.5 & 2.5 & ND & 4.0 & 3.6 & ND \\
\hline & $8 / 9 / 2006$ & str & 7.3 & 2.9 & ND & 6.8 & ND & 3.1 \\
\hline $\begin{array}{l}\text { Pascoag } \\
\text { Reservoir }\end{array}$ & $3 / 3 / 2006$ & str & ND & ND & ND & ND & ND & ND \\
\hline $1 \mathrm{~S}$ & $3 / 31 / 2006$ & str & 37.3 & ND & $\mathrm{ND}$ & ND & ND & ND \\
\hline ID & $3 / 31 / 2006$ & str & 52.8 & ND & ND & ND & ND & ND \\
\hline $2 \mathrm{~S}$ & $3 / 31 / 2006$ & str, $1: 2$ & 219 & 3 & ND & ND & ND & ND \\
\hline \multirow{6}{*}{$2 \mathrm{D}$} & $3 / 31 / 2006$ & str & 25.8 & ND & ND & ND & ND & ND \\
\hline & $6 / 1 / 2006$ & str & 18.6 & ND & ND & ND & ND & ND \\
\hline & $6 / 13 / 2006$ & str & 23.0 & 1.4 & ND & ND & ND & ND \\
\hline & $6 / 23 / 2006$ & str & 24.6 & 1.6 & ND & ND & ND & ND \\
\hline & $7 / 14 / 2006$ & str & 28.4 & ND & ND & ND & ND & ND \\
\hline & $8 / 9 / 2006$ & str & 22.5 & ND & ND & ND & ND & ND \\
\hline $3 \mathrm{~S}$ & $3 / 31 / 2006$ & str, $1: 100$ & 1518 & 0.5 & ND & ND & ND & ND \\
\hline \multirow{2}{*}{$3 \mathrm{D}$} & $3 / 31 / 2006$ & str, $1: 100$ & 2166 & 6.3 & $\mathrm{ND}$ & ND & ND & ND \\
\hline & $8 / 9 / 2006$ & $1: 20,1: 4$ & 1243 & 27.6 & ND & ND & 13.7 & ND \\
\hline $4 S$ & $3 / 31 / 2006$ & str & 54.7 & 0.75 & ND & ND & ND & ND \\
\hline \multirow{11}{*}{$4 \mathrm{D}$} & $3 / 31 / 2006$ & str & 228 & 15.9 & ND & ND & 3.0 & ND \\
\hline & $4 / 21 / 2006$ & str & 188 & 21.7 & 2.2 & ND & 6.0 & ND \\
\hline & $4 / 28 / 2006$ & str & 153 & 18.7 & 4.4 & ND & 5.7 & 1.8 \\
\hline & $5 / 11 / 2006$ & str & 122 & 15.6 & 4.1 & ND & 5.5 & ND \\
\hline & $5 / 20 / 2006$ & str & 106 & 16.1 & 2.7 & ND & 6.2 & ND \\
\hline & $5 / 26 / 2006$ & str & 102 & 13.5 & 2.7 & ND & 5.6 & ND \\
\hline & $6 / 1 / 2006$ & str & 97.0 & 13.3 & 2.5 & ND & 6.0 & ND \\
\hline & $6 / 13 / 2006$ & str & 79.0 & 12.9 & ND & ND & 5.1 & ND \\
\hline & $6 / 23 / 2006$ & str & 66.7 & 10.6 & ND & ND & 3.9 & ND \\
\hline & $7 / 14 / 2006$ & str & 63.1 & 14.4 & 3.3 & ND & 5.5 & ND \\
\hline & $8 / 9 / 2006$ & str & 50.8 & 14.6 & 3.5 & 6.2 & 6.5 & ND \\
\hline $5 \mathrm{~S}$ & $3 / 31 / 2006$ & str & 6.84 & 0.5 & ND & ND & ND & ND \\
\hline \multirow{8}{*}{$5 \mathrm{D}$} & $3 / 31 / 2006$ & str & 50.4 & ND & ND & ND & ND & ND \\
\hline & $5 / 20 / 2006$ & str & 102 & 2.1 & ND & ND & ND & ND \\
\hline & $5 / 26 / 2006$ & str & 33.8 & ND & ND & ND & ND & ND \\
\hline & $6 / 1 / 2006$ & str & 68.4 & ND & ND & ND & ND & ND \\
\hline & $6 / 13 / 2006$ & str & 9.5 & ND & ND & ND & ND & ND \\
\hline & $6 / 23 / 2006$ & str & 6.5 & ND & ND & ND & ND & ND \\
\hline & $7 / 14 / 2006$ & str & 4.0 & ND & ND & ND & ND & ND \\
\hline & $8 / 9 / 2006$ & str & 110 & ND & ND & ND & ND & ND \\
\hline
\end{tabular}




\begin{tabular}{|c|c|c|c|c|c|c|c|c|}
\hline Well & Sample Date & Dilution & MTBE & Benzene & Toluene & Ethylbenzene & m-,p-xylene & 0 -xylene \\
\hline 6S & $3 / 31 / 2006$ & str & 2.9 & ND & ND & ND & ND & ND \\
\hline 6D & $3 / 31 / 2006$ & str & 2.2 & ND & ND & ND & ND & ND \\
\hline
\end{tabular}


Table 18. Ion individual concentrations ( $\mathrm{ND}=$ Not detected).

\begin{tabular}{|c|c|c|c|c|c|c|c|c|c|}
\hline & & & $\overline{\mathrm{TIC}}$ & $(\mathrm{mg} / \mathrm{l}$ & & & $\overline{\mathrm{ANIOI}}$ & $(\mathrm{mg} / \mathrm{L}$ & \\
\hline Well & Date & $\mathrm{Na}^{+}$ & $\mathrm{K}^{+}$ & $\mathrm{Mg}^{2+}$ & $\mathrm{Ca}^{2+}$ & $\mathrm{Cl}^{-}$ & $\mathrm{NO}_{3}^{-}$ & $\mathrm{PO}_{4}{ }^{3-}$ & $\mathrm{SO}_{4}{ }^{2-}$ \\
\hline \multirow{17}{*}{ River at JA IR } & $1 / 21 / 2006$ & $\overline{12.3}$ & 1.1 & 0.6 & 2.5 & 20.0 & 0.7 & $\mathrm{ND}$ & 5.9 \\
\hline & $2 / 5 / 2006$ & 12.4 & 1.0 & 0.6 & 2.3 & 20.4 & 0.7 & $\mathrm{ND}$ & 5.8 \\
\hline & $2 / 20 / 2006$ & 12.0 & 1.0 & 0.6 & 2.3 & 19.4 & 0.6 & $\mathrm{ND}$ & 6.1 \\
\hline & $3 / 3 / 2006$ & 62 & 2.2 & 1.0 & 4.4 & 98 & 0.7 & ND & 7.2 \\
\hline & $3 / 10 / 2006$ & 17.5 & 1.4 & 0.8 & 3.5 & 29.1 & 0.7 & ND & 6.6 \\
\hline & $3 / 28 / 2006$ & 26.0 & 2.0 & 1.3 & 5.5 & 42.8 & 0.8 & 0.4 & 7.8 \\
\hline & $3 / 31 / 2006$ & 27.9 & 2.2 & 1.4 & 5.8 & $\overline{47.2}$ & 0.7 & 0.2 & 7.7 \\
\hline & $4 / 21 / 2006$ & 19.9 & 1.6 & 1.0 & 4.1 & 32.9 & 0.4 & ND & 7.0 \\
\hline & $4 / 28 / 2006$ & 18.7 & 1.5 & 1.0 & 4.0 & 31.1 & 0.5 & ND & 6.8 \\
\hline & $5 / 11 / 2006$ & 25.6 & 1.7 & 1.1 & 4.5 & 32.9 & 0.6 & ND & 6.9 \\
\hline & $5 / 20 / 2006$ & 13.3 & 1.1 & 0.7 & 2.7 & 22.0 & 0.4 & 0.3 & 6.4 \\
\hline & $5 / 26 / 2006$ & 12.8 & 1.0 & 0.6 & 2.6 & 21.0 & 0.3 & ND & 6.2 \\
\hline & $6 / 1 / 2006$ & 12.5 & 1.1 & 0.6 & 2.6 & 20.4 & ND & 0.6 & 6.1 \\
\hline & $6 / 13 / 2006$ & 11.0 & 1.0 & 0.6 & 2.2 & 16.9 & 0.3 & ND & 5.4 \\
\hline & $6 / 23 / 2006$ & 12.8 & 1.1 & 0.7 & 2.7 & 21.0 & 0.4 & ND & 5.4 \\
\hline & $7 / 14 / 2006$ & 12.9 & 1.1 & 0.6 & 2.4 & 35.5 & 0.9 & 0.9 & 5.8 \\
\hline & $8 / 9 / 2006$ & 17.4 & 1.7 & 0.8 & 4.1 & 27.2 & 0.7 & 0.3 & 4.6 \\
\hline \multirow{5}{*}{ River Upstream } & $3 / 3 / 2006$ & 45.4 & 2.1 & 0.9 & 4.5 & $\overline{72}$ & $\overline{0.8}$ & $\mathrm{ND}$ & 6.7 \\
\hline & $3 / 28 / 2006$ & 26.4 & 2.0 & 1.3 & 5.3 & 44.3 & 0.7 & ND & 7.3 \\
\hline & $4 / 21 / 2006$ & 19.8 & 1.6 & 1.0 & 3.8 & 32.4 & ND & $\mathrm{ND}$ & 6.7 \\
\hline & $5 / 20 / 2006$ & 13.6 & 1.2 & 0.6 & 2.4 & 20.9 & 0.3 & $\mathrm{ND}$ & 6.0 \\
\hline & $6 / 13 / 2006$ & 10.9 & 1.0 & 0.5 & 2.1 & 15.7 & 0.3 & $\mathrm{ND}$ & 5.1 \\
\hline \multirow{14}{*}{ JA IRB } & $2 / 20 / 2006$ & 13.0 & 1.5 & 1.0 & 6.0 & 20.8 & 0.3 & ND & 9.4 \\
\hline & $3 / 3 / 2006$ & 12.1 & 1.3 & 1.0 & 5.2 & 19.6 & 0.4 & ND & 7.7 \\
\hline & $3 / 10 / 2006$ & 12.6 & 1.3 & 1.0 & 5.6 & 19.9 & ND & ND & 7.4 \\
\hline & $3 / 28 / 2006$ & 13.9 & 1.5 & 1.2 & 6.6 & 22.1 & 0.3 & ND & 8.3 \\
\hline & $4 / 21 / 2006$ & 22.2 & 2.1 & 1.5 & 8.7 & 26.3 & ND & 1.2 & 6.7 \\
\hline & $4 / 28 / 2006$ & 16.2 & 1.9 & 1.6 & 9.3 & 26.4 & ND & ND & 6.9 \\
\hline & $5 / 11 / 2006$ & 18.1 & 2.2 & 1.9 & 10.5 & 30.8 & 0.7 & $\mathrm{ND}$ & 8.4 \\
\hline & $5 / 20 / 2006$ & 21.4 & 2.9 & 2.4 & 13.0 & 37.5 & 0.3 & ND & 7.8 \\
\hline & $5 / 26 / 2006$ & 19.3 & 2.6 & 2.2 & 11.8 & 34.7 & $\overline{N D}$ & ND & 5.4 \\
\hline & $6 / 1 / 2006$ & 18.0 & 2.6 & 2.0 & 10.5 & 32.0 & $\mathrm{ND}$ & ND & 4.0 \\
\hline & $6 / 13 / 2006$ & 14.8 & 1.8 & 1.4 & 7.4 & 23.3 & 0.3 & ND & 8.3 \\
\hline & $6 / 23 / 2006$ & 18.8 & 2.4 & 1.9 & 10.3 & 32.3 & 1.2 & $\mathrm{ND}$ & 12.4 \\
\hline & $7 / 14 / 2006$ & 22.2 & 3.3 & 2.3 & 12.5 & 39.5 & 2.9 & ND & 13.6 \\
\hline & $8 / 9 / 2006$ & 22.4 & 3.8 & 2.6 & 14.2 & 40.1 & $\mathrm{ND}$ & ND & 11.8 \\
\hline \multirow{15}{*}{ JA $2 S$} & $2 / 5 / 2006$ & 19.3 & 3.4 & 3.3 & 27.6 & 36.9 & ND & ND & 1.7 \\
\hline & $2 / 20 / 2006$ & 18.7 & 3.2 & 3.1 & 25.3 & 35.3 & ND & ND & 2.4 \\
\hline & $3 / 3 / 2006$ & 19.1 & 3.4 & 3.1 & 25.5 & 31.1 & $\mathrm{ND}$ & ND & 2.3 \\
\hline & $3 / 10 / 2006$ & 19.3 & 3.2 & 3.3 & 26.1 & 34.5 & ND & ND & 2.1 \\
\hline & $3 / 28 / 2006$ & 21.7 & 3.4 & 4.0 & 31.0 & 42.9 & ND & ND & 1.6 \\
\hline & $4 / 21 / 2006$ & 22.4 & 3.6 & 4.1 & 31.9 & 40.8 & ND & ND & 1.8 \\
\hline & $4 / 28 / 2006$ & 16.2 & 3.0 & 2.6 & 20.3 & 26.9 & ND & ND & 3.2 \\
\hline & $5 / 11 / 2006$ & 19.5 & 3.1 & 3.2 & 25.6 & 34.7 & $\overline{N D}$ & ND & 2.6 \\
\hline & $5 / 20 / 2006$ & 23.4 & 3.5 & 4.0 & 31.9 & 48.2 & 1.5 & ND & 1.0 \\
\hline & $5 / 26 / 2006$ & 26.7 & 4.3 & 4.9 & 37.5 & 53 & $\mathrm{ND}$ & ND & 0.6 \\
\hline & $6 / 1 / 2006$ & 27.1 & 4.4 & 4.3 & 32.9 & 45.7 & ND & ND & 1.1 \\
\hline & $6 / 13 / 2006$ & 22.0 & 2.8 & 1.9 & 14.5 & 19.8 & $\mathrm{ND}$ & ND & 4.0 \\
\hline & $6 / 23 / 2006$ & 25.8 & 4.3 & 4.7 & 36.6 & 50 & $\mathrm{ND}$ & ND & 0.9 \\
\hline & $7 / 14 / 2006$ & 26.1 & 4.5 & 4.5 & 35.5 & 50 & $\mathrm{ND}$ & ND & 1.0 \\
\hline & $8 / 9 / 2006$ & 29.7 & 5.0 & 5.5 & 43.4 & 64 & ND & ND & 0.5 \\
\hline
\end{tabular}




\begin{tabular}{|c|c|c|c|c|c|c|c|c|c|}
\hline \multirow[b]{2}{*}{ Well } & \multirow[b]{2}{*}{ Date } & \multicolumn{4}{|c|}{ CATIONS (mg/L) } & \multicolumn{4}{|c|}{ ANIONS $(\mathrm{mg} / \mathrm{L})$} \\
\hline & & $\mathrm{Na}^{+}$ & $\mathrm{K}^{+}$ & $\mathrm{Mg}^{2+}$ & $\mathrm{Ca}^{2+}$ & $\mathrm{Cl}^{-}$ & $\mathrm{NO}_{3}^{-}$ & $\mathrm{PO}_{4}{ }^{3-}$ & $\mathrm{SO}_{4}{ }^{2-}$ \\
\hline \multirow{14}{*}{ JA 2D } & $2 / 5 / 2006$ & 34.1 & 7.0 & 6.0 & 29.0 & 67 & 6.3 & $\mathrm{ND}$ & 8.8 \\
\hline & $2 / 20 / 2006$ & 41.6 & 6.1 & 6.7 & 36.0 & 90 & 2.2 & 0.7 & 6.8 \\
\hline & $3 / 3 / 2006$ & 27.5 & 5.0 & 4.4 & 21.9 & 50.0 & 4.8 & ND & 12.0 \\
\hline & $3 / 10 / 2006$ & 29.7 & 5.1 & 4.3 & 20.5 & 47.7 & 6.3 & ND & 13.3 \\
\hline & $3 / 28 / 2006$ & 27.6 & 5.0 & 4.8 & 23.5 & 55 & 5.5 & ND & 12.2 \\
\hline & $4 / 28 / 2006$ & 29.4 & 5.0 & 4.8 & 22.4 & 53 & 7.0 & ND & 11.1 \\
\hline & $5 / 11 / 2006$ & 31.5 & 5.3 & 5.8 & 27.9 & 65 & 4.5 & ND & 10.5 \\
\hline & $5 / 20 / 2006$ & 41.7 & 6.1 & 8.3 & 43.0 & 84 & 2.7 & ND & 26.4 \\
\hline & $5 / 26 / 2006$ & 33.4 & 5.4 & 6.2 & 30.2 & 67 & 4.5 & ND & 11.7 \\
\hline & $6 / 1 / 2006$ & 38.6 & 5.7 & 6.9 & 35.2 & 76 & 2.8 & ND & 6.5 \\
\hline & $6 / 13 / 2006$ & 42.0 & 5.9 & 7.6 & 39.6 & 87 & 2.3 & 0.3 & 5.2 \\
\hline & $6 / 23 / 2006$ & 25.3 & 4.8 & 4.3 & 19.8 & 49.8 & 5.3 & ND & 11.6 \\
\hline & $7 / 14 / 2006$ & 26.6 & 4.6 & 4.4 & 20.6 & 48.2 & 3.0 & ND & 10.9 \\
\hline & $8 / 9 / 2006$ & 30.6 & 5.4 & 6.0 & 27.5 & 66 & 4.2 & ND & 13.3 \\
\hline \multirow{17}{*}{ JA 3S } & $1 / 21 / 2006$ & 32.9 & 6.8 & 6.7 & 58 & 61 & ND & ND & 0.6 \\
\hline & $1 / 24 / 2006$ & 31.4 & 6.5 & 6.5 & 55 & 60 & ND & ND & 0.6 \\
\hline & $2 / 5 / 2006$ & 28.3 & 5.9 & 5.6 & 46.0 & 58 & ND & ND & 0.8 \\
\hline & $2 / 20 / 2006$ & 34.0 & 6.6 & 6.9 & 58 & 67 & ND & ND & $\mathrm{ND}$ \\
\hline & $3 / 3 / 2006$ & 34.9 & 6.7 & 7.2 & 60 & 67 & ND & ND & ND \\
\hline & $3 / 10 / 2006$ & 34.6 & 6.7 & 7.3 & 60 & 68 & ND & $\mathrm{ND}$ & ND \\
\hline & $3 / 28 / 2006$ & 35.5 & 6.7 & 7.5 & 62 & 70 & ND & ND & ND \\
\hline & $4 / 21 / 2006$ & 34.1 & 6.6 & 7.2 & 59 & 66 & ND & ND & ND \\
\hline & $4 / 28 / 2006$ & 33.2 & 6.3 & 6.3 & 52 & 60 & $\overline{N D}$ & ND & 0.7 \\
\hline & $5 / 11 / 2006$ & 28.6 & 5.7 & 5.7 & 46.4 & 51 & ND & ND & 0.6 \\
\hline & $5 / 20 / 2006$ & 30.9 & 5.5 & 4.9 & 37.5 & 39.8 & ND & ND & 0.7 \\
\hline & $5 / 26 / 2006$ & 33.5 & 6.8 & 7.0 & 58 & 61 & ND & ND & ND \\
\hline & $6 / 1 / 2006$ & 33.2 & 6.8 & 7.0 & 57 & 60 & ND & ND & ND \\
\hline & $6 / 13 / 2006$ & 19.4 & 4.8 & 3.6 & 24.5 & 28.1 & $\overline{N D}$ & ND & 1.5 \\
\hline & $6 / 23 / 2006$ & 32.6 & 7.0 & 6.8 & 55 & 53 & ND & ND & 1.0 \\
\hline & $7 / 14 / 2006$ & 32.8 & 7.2 & 6.5 & 53 & 54 & ND & ND & 1.3 \\
\hline & $8 / 9 / 2006$ & 33.2 & 7.6 & 7.0 & 60 & 63 & ND & ND & 9.8 \\
\hline \multirow{17}{*}{ JA 3D } & $1 / 21 / 2006$ & 56 & 8.7 & 7.7 & 44.6 & 112 & 0.5 & ND & 11.1 \\
\hline & $1 / 24 / 2006$ & 53 & 6.2 & 7.9 & 38.1 & 114 & ND & ND & 14.0 \\
\hline & $2 / 5 / 2006$ & 48.8 & 5.6 & 7.6 & 34.6 & 112 & ND & ND & 14.8 \\
\hline & $2 / 20 / 2006$ & 50 & 5.9 & 8.2 & 38.6 & 111 & 0.4 & ND & 12.7 \\
\hline & $3 / 3 / 2006$ & 49.1 & 6.0 & 8.1 & 39.1 & 106 & 0.5 & ND & 10.8 \\
\hline & $3 / 10 / 2006$ & 44.3 & 4.9 & 6.7 & 30.7 & 97 & 1.4 & ND & 14.8 \\
\hline & $3 / 28 / 2006$ & 44.8 & 4.8 & 6.9 & 30.2 & 101 & 1.4 & ND & 14.9 \\
\hline & $4 / 21 / 2006$ & 50 & 5.2 & 8.5 & 39.2 & 118 & 0.5 & ND & 18.9 \\
\hline & $4 / 28 / 2006$ & 52 & 5.5 & 9.4 & 46.5 & 105 & ND & ND & 22.8 \\
\hline & $5 / 11 / 2006$ & 57 & 5.5 & 10.0 & 47.0 & 119 & ND & ND & 22.2 \\
\hline & $5 / 20 / 2006$ & 63 & 6.1 & 11.9 & 61 & 129 & ND & ND & 37.8 \\
\hline & $5 / 26 / 2006$ & 69 & 6.1 & 11.8 & 58 & & & & \\
\hline & $6 / 1 / 2006$ & 67 & 6.5 & 12.8 & 70 & 126 & ND & ND & 52 \\
\hline & $6 / 13 / 2006$ & 65 & 6.1 & 9.2 & 46.4 & 129 & ND & ND & 14.9 \\
\hline & $6 / 23 / 2006$ & 59 & 5.8 & 8.3 & 45.0 & 122 & ND & ND & 21.5 \\
\hline & $7 / 14 / 2006$ & 64 & 6.0 & 8.6 & 45.1 & 136 & ND & ND & 13.5 \\
\hline & $8 / 9 / 2006$ & 66 & 6.6 & 10.5 & 64 & 144 & ND & ND & 40.2 \\
\hline
\end{tabular}




\begin{tabular}{|c|c|c|c|c|c|c|c|c|c|}
\hline & & & $\overline{\mathrm{ATIO}}$ & $(\mathrm{mg} / \mathrm{l}$ & & & $\overline{\mathrm{ANIOI}}$ & $\overline{(\mathrm{mg} / \mathrm{L})}$ & \\
\hline Well & Date & $\mathrm{Na}^{+}$ & $\mathrm{K}^{+}$ & $\mathrm{Mg}^{2+}$ & $\mathrm{Ca}^{2+}$ & $\mathrm{Cl}^{-}$ & $\mathrm{NO}_{3}{ }^{-}$ & $\mathrm{PO}_{4}{ }^{3-}$ & $\mathrm{SO}_{4}{ }^{2}$ \\
\hline \multirow{15}{*}{ MW 18} & $1 / 24 / 2006$ & 52 & 5.0 & 4.7 & 25.1 & 86 & ND & ND & 6.3 \\
\hline & $2 / 20 / 2006$ & 72 & 5.9 & 6.5 & 36.7 & 146 & ND & ND & 5.6 \\
\hline & $3 / 3 / 2006$ & 67 & 5.7 & 6.4 & 38.6 & 136 & ND & ND & 9.6 \\
\hline & $3 / 10 / 2006$ & 83 & 6.3 & 7.7 & 39.8 & & ND & ND & 4.8 \\
\hline & $3 / 28 / 2006$ & 68 & 5.7 & 7.0 & 44.7 & 134 & ND & ND & \\
\hline & $4 / 21 / 2006$ & 80 & 6.1 & 7.4 & 39.8 & 142 & ND & ND & 6.8 \\
\hline & $4 / 28 / 2006$ & 57 & 5.3 & 5.7 & 36.0 & 106 & ND & ND & 14.2 \\
\hline & $5 / 11 / 2006$ & 42.9 & 4.1 & 4.1 & 25.8 & 75 & ND & ND & 6.7 \\
\hline & $5 / 20 / 2006$ & 45.7 & 4.1 & 4.0 & 22.4 & 81 & 0.3 & ND & 3.9 \\
\hline & $5 / 26 / 2006$ & 83 & 6.3 & 7.2 & 37.7 & 150 & ND & ND & 3.5 \\
\hline & $6 / 1 / 2006$ & 69 & 5.7 & 6.0 & 33.0 & 126 & ND & ND & 4.7 \\
\hline & $6 / 13 / 2006$ & 54 & 4.7 & 4.6 & 27.8 & 100 & ND & ND & 5.1 \\
\hline & $6 / 23 / 2006$ & 76 & 6.2 & 6.4 & 36.0 & 139 & ND & ND & 4.4 \\
\hline & $7 / 14 / 2006$ & 83 & 6.6 & 6.8 & 36.1 & 151 & ND & ND & 2.8 \\
\hline & $8 / 9 / 2006$ & 76 & 6.3 & 5.8 & 31.9 & 130 & ND & ND & $\overline{6.4}$ \\
\hline \multirow{15}{*}{ MW 18D } & $1 / 24 / 2006$ & 94 & 6.7 & 7.9 & 43.1 & 170 & ND & ND & 4.3 \\
\hline & $2 / 20 / 2006$ & 98 & 6.6 & 8.5 & 45.7 & 180 & ND & ND & 3.9 \\
\hline & $3 / 3 / 2006$ & 99 & 6.5 & 8.6 & 46.3 & 184 & ND & $\mathrm{ND}$ & 3.8 \\
\hline & $3 / 10 / 2006$ & 98 & 6.5 & 8.6 & 46.8 & 187 & ND & ND & 3.8 \\
\hline & $3 / 28 / 2006$ & 97 & 6.4 & 8.4 & 46.2 & 188 & ND & ND & 3.9 \\
\hline & $4 / 21 / 2006$ & 95 & 6.3 & 8.1 & 45.6 & 181 & ND & ND & 3.7 \\
\hline & $4 / 28 / 2006$ & 96 & 6.3 & 8.2 & 46.2 & 185 & ND & ND & 3.6 \\
\hline & $5 / 11 / 2006$ & 92 & 6.2 & 7.7 & 43.8 & 177 & ND & ND & 3.5 \\
\hline & $5 / 20 / 2006$ & 90 & 6.0 & 7.1 & 42.1 & 170 & ND & ND & 3.8 \\
\hline & $5 / 26 / 2006$ & 91 & 6.1 & 7.4 & 42.9 & 174 & ND & ND & 3.9 \\
\hline & $6 / 1 / 2006$ & 95 & 6.3 & 7.9 & 45.4 & 183 & ND & ND & 4.0 \\
\hline & $6 / 13 / 2006$ & 98 & 6.3 & 8.1 & 46.8 & 188 & ND & ND & 3.5 \\
\hline & $6 / 23 / 2006$ & 92 & 6.1 & 7.1 & 42.6 & 175 & ND & ND & 3.6 \\
\hline & $7 / 14 / 2006$ & 91 & 6.1 & 6.9 & 41.6 & 173 & ND & ND & 3.6 \\
\hline & $8 / 9 / 2006$ & 91 & 6.3 & 6.7 & 39.8 & 170 & ND & ND & 3.6 \\
\hline \multirow{14}{*}{ MW 44} & $1 / 24 / 2006$ & 61 & 6.8 & 7.3 & 46.3 & & ND & ND & 3.0 \\
\hline & $3 / 3 / 2006$ & 69 & 7.2 & 8.4 & 52 & 138 & ND & ND & $\overline{N D}$ \\
\hline & $3 / 10 / 2006$ & 72 & 7.4 & 8.2 & .50 & 149 & ND & ND & 2.3 \\
\hline & $3 / 28 / 2006$ & 82 & 8.1 & 9.1 & 54 & 175 & ND & ND & 2.1 \\
\hline & $4 / 21 / 2006$ & & & & & 145 & ND & ND & 3.0 \\
\hline & $4 / 28 / 2006$ & 86 & 8.5 & 9.2 & 56 & 186 & ND & ND & 1.7 \\
\hline & $5 / 11 / 2006$ & 86 & 8.6 & 9.2 & 58 & 187 & ND & ND & 1.4 \\
\hline & $5 / 20 / 2006$ & 83 & 8.4 & 9.1 & 58 & 181 & ND & $\mathrm{ND}$ & 1.2 \\
\hline & $5 / 26 / 2006$ & 84 & 8.6 & 9.3 & 61 & 187 & ND & ND & 1.2 \\
\hline & $6 / 1 / 2006$ & 83 & 8.6 & 9.1 & 59 & 185 & ND & ND & 1.3 \\
\hline & $6 / 13 / 2006$ & 65 & 7.7 & 7.9 & 56 & 144 & ND & ND & 1.1 \\
\hline & $6 / 23 / 2006$ & 77 & 8.5 & 8.9 & 58 & 165 & ND & ND & 1.2 \\
\hline & $7 / 14 / 2006$ & 82 & 9.0 & 8.9 & 57 & 169 & ND & ND & 1.2 \\
\hline & $8 / 9 / 2006$ & 82 & 9.0 & 8.7 & 55 & 170 & ND & ND & 1.2 \\
\hline
\end{tabular}




\begin{tabular}{|c|c|c|c|c|c|c|c|c|c|}
\hline & & & $\overline{\mathrm{ATIO}}$ & (mg/l & & & $\overline{\mathrm{ANIOI}}$ & $(\mathrm{mg} / \mathrm{L}$ & \\
\hline Well & Date & $\mathrm{Na}^{+}$ & $\mathrm{K}^{+}$ & $\mathrm{Mg}^{2+}$ & $\mathrm{Ca}^{2+}$ & $\mathrm{Cl}^{-}$ & $\mathrm{NO}_{3}^{-}$ & $\mathrm{PO}_{4}{ }^{3-}$ & $\mathrm{SO}_{4}{ }^{2-}$ \\
\hline \multirow{13}{*}{ MW 56} & $1 / 24 / 2006$ & 4.5 & 6.4 & 0.6 & 440 & 6.2 & 4.8 & ND & 1025 \\
\hline & $3 / 3 / 2006$ & 4.7 & 6.2 & ND & 336 & 3.1 & 1.3 & ND & 807 \\
\hline & $3 / 10 / 2006$ & 4.8 & 5.9 & 0.5 & 264 & 3.4 & 0.3 & ND & 624 \\
\hline & $3 / 28 / 2006$ & 4.4 & 5.5 & 0.4 & 194 & 3.8 & 0.5 & ND & 478 \\
\hline & $4 / 21 / 2006$ & 4.8 & 5.6 & 0.4 & 148 & 4.6 & 0.6 & ND & 351 \\
\hline & $4 / 28 / 2006$ & 5.0 & 5.3 & 0.3 & 110 & 5.8 & 0.7 & ND & 284 \\
\hline & $5 / 11 / 2006$ & 5.3 & 5.0 & ND & 113 & 5.4 & 2.9 & ND & 275 \\
\hline & $5 / 20 / 2006$ & 10.7 & 7.5 & 0.7 & 320 & 1.7 & 4.3 & 0.1 & 785 \\
\hline & $6 / 1 / 2006$ & 3.8 & 4.2 & ND & 200 & 3.2 & 3.4 & ND & 532 \\
\hline & $6 / 13 / 2006$ & 4.5 & 4.3 & ND & 160 & 2.2 & 6.2 & ND & 358 \\
\hline & $6 / 23 / 2006$ & 4.1 & 3.6 & ND & 110 & 4.5 & 6.8 & ND & 200 \\
\hline & $7 / 14 / 2006$ & 6.1 & 5.3 & ND & 115 & 3.3 & 1.0 & ND & 256 \\
\hline & $8 / 9 / 2006$ & 6.9 & 5.8 & ND & 98 & 3.7 & ND & ND & 189 \\
\hline \multirow{2}{*}{ Pascoag Reservoir } & $1 / 24 / 2006$ & 11.0 & 0.9 & 0.5 & 1.9 & 17.0 & 0.6 & ND & 5.6 \\
\hline & $3 / 3 / 2006$ & 11.5 & 1.0 & 0.5 & 2.1 & 18.0 & 0.4 & ND & 5.8 \\
\hline
\end{tabular}




\section{BIBLIOGRAPHY}

Allen, J.L. 2005. Quaternary Geologic Map of the Chepachet Quadrangle, Rhode Island Unpublished report.

Allen, J.L., and T.B. Boving. 2006. Summary of 2005 aquifer test and groundwater flow dynamics, Pascoag, Rhode Island. Technical Report submitted to the RI Department of Environmental Management.

Ayotte, J.D., D.M. Argue, and F.J. McGarry. 2005. Methyl tert-butyl ether occurrence and related factors in public and private wells in southeast New Hampshire. Environmental Science \& Technology 39, no. 1: 9-16.

Barlow, L.K. 2003. Estimated water use and availability in the Lower Blackstone River Basin, northern Rhode Island and south-central Massachusetts, 1995-99. USGS Water-Resources Investigations Report 03-4190.

Barlow, P.M., L.A. DeSimone, and A.F. Moench. 2000. Aquifer response to streamstage and recharge variations II. Convolution method and applications. Journal of Hydrology 230: 211-229.

Becker, M.W., T. Georgian, H. Ambrose, J. Siniscalchi, and K. Fredrick. 2004. Estimating flow and flux of ground water discharge using water temperature and velocity. Journal of Hydrology 296: 221-233.

Boano, F., R. Revelli, and L. Ridolfi. 2007. Bedform-induced hyporheic exchange with unsteady flows. Advances in Water Resources 30, no. 1: 148-156.

Bouarfa, S., and D. Zimmer. 2000. Water-table shapes and drain flow rates in shallow drainage systems. Journal of Hydrology 235: 264-275.

Burrillville Preservation and Historical Society. 2005. http://www.onfrozenpond.com/ people-bhps.htm. Accessed 11/21/05.

Burt, T.P., P.D. Bates, M.D. Stewart, A.J. Claxton, M.G. Anderson, and D.A. Price. 2002. Water table fluctuations within the floodplain of the River Severn, England. Journal of Hydrology 262: 1-20.

Burt, T.P., G. Pinay, F.E. Matheson, N.E. Haycock, A. Butturini, J.C. Clement, S. Danielescu, D.J. Dowrick, M.M. Hefting, A. Hillbricht-Ilkoska, and V. Maitre. 2002. Water table fluctuations in the riparian zone: comparative results from a pan-European experiment. Journal of Hydrology 265: 129-148. 
Job, C.A., and J.J. Simons. 1996. Ground and surface water interaction, watershed management, and monitoring. Ground Water 16, no. 3: 68-69.

Johnson, A.N., B.R. Boer, W.W. Woessner, J.A. Stanford, G.C. Poole, S.A. Thomas, and S.J. O'Daniel. Ground Water Monitoring \& Remediation 25, no. 4: 68-74.

Jonsson, K., H. Johansson, and A. Wörman. 2003. Hyporheic exchange of reactive and conservative solutes in streams - tracer methodology and model interpretation. Journal of Hydrology 278: 153-171.

Kasahara, T., and S.M. Wondzell. 2003. Geomorphic controls on hyporheic exchange flow in mountain streams. Water Resources Research 39, no. 1: 1005-1116.

Kim, H., and H.F. Hemond. 1998. Natural discharge of volatile organic compounds from contaminated aquifer to surface water. Journal of Environmental Engineering 124, no. 8: 744-751.

Lal, A.M.W. 2001. Modification of canal flow due to stream-aquifer interaction. Journal of Hydraulic Engineering 127, no. 7: 567-576.

Lambs, L. 2004. Interactions between groundwater and surface water at river banks and the confluence of rivers. Journal of Hydrology 288: 312-326.

Landmeyer, J.E., F.H. Chapelle, H.H. Herlong, and P.M. Bradley. 2001. Methyl tertbutyl ether biodegradation by indigenous aquifer microorganisms under natural and artificial oxic conditions. Environmental Science \& Technology 35, no. 6: 1118-1126.

Langhoff, J.H., K.R. Rasmussen, and S. Christensen. 2006. Quantification and regionalization of groundwater-surface water interaction along an alluvial stream. Journal of Hydrology 320: 342-358.

Lautz, L.K., and D.I. Siegel. 2006. Modeling surface and ground water mixing in the hyporheic zone using MODFLOW and MT3D. Advances in Water Resources 29, no. 11: 1618-1633.

Laserbeams.com. 2006. www.laserbeams.com. Accessed 09/06.

Lee, R.L. 1977. A device for measuring seepage flux in lakes and estuaries. Limnology and Oceanography 22, no. 1: 140-147.

Missouri Census Data Center. 2006. http://mcdc2.missouri.edu/cgi-bin/broker? PROGRAM=websas.dp3_2k.sas\&_SERVICE=sasapp\&zi=02859. Accessed $12 / 06$. 
Moran, M.J., J.S. Zogorski, and P.J. Squillace. 2005. MTBE and gasoline hydrocarbons in ground water of the United States. Ground Water 43, no. 4: 615-627.

National Climatic Data Center (NCDC).2006. www1.ncdc.noaa.gov. Accessed 10/06.

Nichols, D.S., and E.S. Verry. 2001. Stream flow and ground water recharge from small forested watersheds in north central Minnesota. Journal of Hydrology 245: 89-103.

Nielson, P., R. Aseervatham, J.D. Fenton, and P. Perrochet. 1997. Groundwater waves in aquifers of intermediate depths. Advances in Water Resources 20, no. 1:3743.

Oklahoma Water Resources Board. 2004. Water quality programs division: standard operating procedure for the use of floats to determine stream discharge. Oklahoma City, Oklahoma.

Plouffe, L. 2006. Personal communication.

Puls, R.W., and M.J. Barcelona. 1996. Ground water issue: low-flow (minimal drawdown) ground-water sampling procedures. EPA/540/S-95/504.

Quinn, A.W. 1967. Bedrock Geology of the Chepachet Quadrangle, Providence County, Rhode Island. Geological Survey Bulletin 1241-G, Plate 1.

Rao, N.H., and P.B.S Sarma. 1980. Growth of ground-water mound in response to recharge. Ground Water 18, no. 6: 587-595.

Rector, D.D. 1981. Soil survey of Rhode Island: United States Department of Agriculture Soil Conservation Service in Cooperation with Rhode Island Agricultural Experiment Station.

Rhode Island Department of Environmental Management (RIDEM) unpublished data

Rhode Island Geographic Information Systems. 2006. http://www.edc.uri.edu/rigis/ aerialse/ aerial1939/39Northindex.htm. Accessed 04/06.

Ritter, D.F., R.C. Kochel, and J.R. Miller. 2002. Process Geomorphology, $4^{\text {th }}$ ed. New York: McGraw-Hill.

Runkel, R.L., D.M. McKnight, and H. Rajaram. 2003. Preface: modeling hyporheic zone processes. Advances in Water Resources 26: 901-905.

Saines, M. 1981. Errors in interpretation of ground-water level data. Ground Water Monitoring Review 1, no. 1: 56-61. 
Schilling, K.E., Y.-K. Zhang, and P. Drobney. 2004. Water table fluctuations near an incised stream, Walnut Creek, Iowa. Journal of Hydrology 286: 236-248.

Schilling, K.E., Z. Li, and Y.-K. Zhang. 2006. Groundwater-surface water interaction in the riparian zone of an incised channel, Walnut Creek, Iowa. Journal of Hydrology 327: 140-150.

Schot, P., and T. Winter. 2006. Ground water-surface water interactions in wetlands for integrated water resources management. Journal of Hydrology 320: 261263.

Schubert, J. 2002. Hydraulic aspects of riverbank filtration—field studies. Journal of Hydrology 266: 145-161.

Serrano, S., and S.R. Workman. 1998. Modeling transient stream/aquifer interaction with the non-linear Boussinesq equation and its analytical solution. Journal of Hydrology 206: 245-255.

Sevee, J.E., C.A. White, and D.J. Maher. 2000. An analysis of low-flow ground water sampling methodology. Ground Water Monitoring \& Remediation 20, no. 2: 87-93.

Sheets, R.A., R.A. Darner, and B.L. Whitteberry. 2002. Lag times of bank filtration at a well field, Cincinnati, Ohio, USA. Journal of Hydrology 266: 162-174.

Sklash, M.G., and R.N. Farvolden. 1979. The role of groundwater in storm runoff. Journal of Hydrology 43: 45-65.

Sophocleous, M., M.A. Townsend, L.D. Vogler, T.J. McClain, E.T. Marks, and G.R. Coble. 1988. Experimental studies in stream-aquifer interaction along the Arkansas River in Central Kansas-field testing and analysis. Journal of Hydrology 98: 249-273.

Springer, A.E., J.M. Wright, P.B. Shafroth, J.C. Stromberg, and D.T. Patten. 1999. Coupling groundwater and riparian vegetation models to assess effects of reservoir releases. Water Resources Research 35, no. 12: 3621-3630.

Stewart, M.P., P.D. Bates, M.G. Anderson, D.A. Price, and T.P. Burt. 1999. Modeling floods in hydrologically complex lowland river reaches. Journal of Hydrology 223: 85-106.

Stonestrom, D.A., and J. Constantz. 2004. Using temperature to study stream-ground water exchanges. USGS Fact Sheet 2004-3010. 
Supriyasilp, T., A.J. Graettinger, and S.R. Durrans. 2003, Quantitatively directed sampling for main channel and hyporheic zone water-quality modeling. Journal of Water Resources 26: 1029-1037.

Tomassoni, G. 2000. A federal statutory/regulatory/policy perspective on remedial decision-making with respect to ground-water/surface-water interaction. In Proceedings of the ground-water/surface-water interactions workshop, 13-14: EPA/542/R-00/007.

Triska, F.J., V.C. Kennedy, R.J. Avanzino, G.W. Zellweger, and K.E. Bencala. 1989. Retention and transport of nutrients in a third-order stream in northwestern California: hyporheic processes. Ecology 70, no. 6: 1893-1905.

Upadhyaya, A., and H.S. Chauhan. 2001. Water table fluctuations due to canal seepage and time varying recharge. Journal of Hydrology 244: 1-8.

USEPA. 2007. http://oaspub.epa.gov/tmdl/enviro_v2.wcontrol?p_id305b= RI0001002L- 03. Accessed 01/07.

Vidon, P.G.F., and A.R. Hill. 2004. Landscape controls on the hydrology of stream riparian zones. Journal of Hydrology 292: 210-228.

WeatherUnderground. 2006. http://www.weatherunderground.com/weatherstation/ WXDailyHistory.asp?ID=KRIPASCO1\&day $=30 \&$ year $=2006 \&$ month $=4 \&$ grap hspan=3month. Accessed 05/06 through 10/06.

Westbrook, S.L., J.L. Rayner, G.B. Davis, T.P. Clement, P.L. Bjerg, and S.J. Fisher. 2005. Interaction between shallow groundwater, saline surface water and contaminant discharge at a seasonally and tidally forced estuarine boundary. Journal of Hydrology 302: 255-269.

Wett, B., H. Jarosh, and K. Ingerle. 2002. Flood induced infiltration affecting a bank filtrate well at the River Enns, Austria. Journal of Hydrology 266: 222-234.

White, D.S. 1993. Perspectives on defining and delineating hyporheic zones. Journal of the North American Benthological Society 12. no. 1:61-69.

Winter, T.C., J.W. Harvey, O.L. Franke, and W.M. Alley. 1998. Ground water and surface water: a single resource. USGS Circular 1139.

Woessner, W.W. 2000. Stream and fluvial plain ground water interactions: rescaling hydrogeologic thought: Ground Water 38, no. 3: 423-429.

Wroblicky, G.J., M.E. Campana, H.H. Valett, and C.N. Dahm. 1998. Seasonal variation in surface-subsurface water exchange and lateral hyporheic area of two stream-aquifer systems. Water Resources Research 34, no. 3: 317-328. 
Zhang, Y.-K., and K.E. Schilling. 2006. Effects of land cover on water table, soil moisture, evapotranspiration, and groundwater recharge: A field observation and analysis. Journal of Hydrology 319: 328-338.

Zlotnik, V.A., and H. Huang. 1999. Effect of shallow penetration and streambed sediments on an aquifer response to stream stage fluctuations (analytical model). Ground Water 37, no. 4: 599-605. 